\title{
Conceptual Model of Primary Mercury Sources, Transport Pathways, and Flux at the Y-12 Complex and Upper East Fork Poplar Creek, Oak Ridge, Tennessee
}

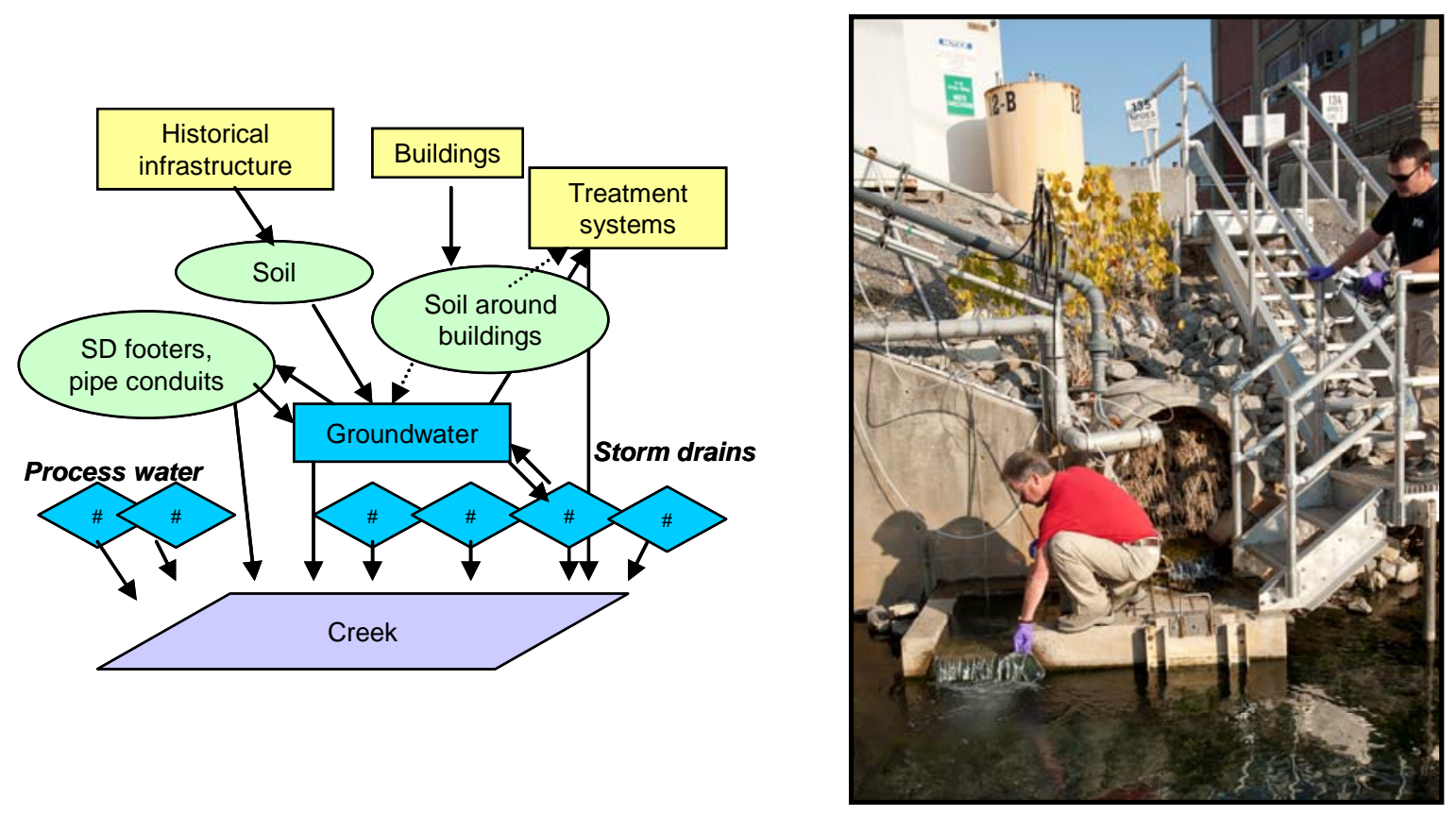

This document has been reviewed and is determined to be APPROVED FOR PUBLIC RELEASE.

Name/Title: Leesa Laymance/ORNL TIO

Date: $\underline{2 / 21 / 2018}$
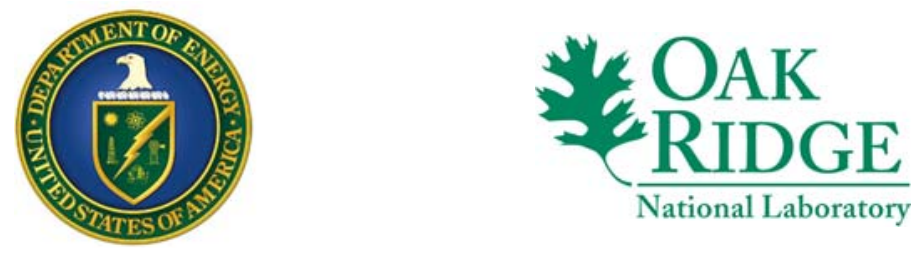

March 2011 


\title{
DOCUMENT AVAILABILITY
}

Reports produced after January 1, 1996, are generally available free via the U.S. Department of Energy (DOE) Information Bridge.

Web site http://www.osti.gov/bridge

Reports produced before January 1, 1996, may be purchased by members of the public from the following source.

\author{
National Technical Information Service \\ 5285 Port Royal Road \\ Springfield, VA 22161 \\ Telephone 703-605-6000 (1-800-553-6847) \\ TDD 703-487-4639 \\ Fax 703-605-6900 \\ E-mail info@ntis.gov \\ Web site http://www.ntis.gov/support/ordernowabout.htm
}

Reports are available to DOE employees, DOE contractors, Energy Technology Data Exchange (ETDE) representatives, and International Nuclear Information System (INIS) representatives from the following source.

Office of Scientific and Technical Information

P.O. Box 62

Oak Ridge, TN 37831

Telephone 865-576-8401

Fax 865-576-5728

E-mail reports@osti.gov

Web site http://www.osti.gov/contact.html

This report was prepared as an account of work sponsored by an agency of the United States Government. Neither the United States Government nor any agency thereof, nor any of their employees, makes any warranty, express or implied, or assumes any legal liability or responsibility for the accuracy, completeness, or usefulness of any information, apparatus, product, or process disclosed, or represents that its use would not infringe privately owned rights. Reference herein to any specific commercial product, process, or service by trade name, trademark, manufacturer, or otherwise, does not necessarily constitute or imply its endorsement, recommendation, or favoring by the United States Government or any agency thereof. The views and opinions of authors expressed herein do not necessarily state or reflect those of the United States Government or any agency thereof. 


\title{
Conceptual Model of Primary Mercury Sources, Transport Pathways, and Flux at the Y-12 Complex and Upper East Fork Poplar Creek, Oak Ridge, Tennessee
}

\author{
Mark Peterson ${ }^{1}$ \\ Brian Looney ${ }^{2}$ \\ George Southworth ${ }^{1}$ \\ Carol Eddy-Dilek ${ }^{2}$ \\ David Watson ${ }^{1}$ \\ Richard Ketelle ${ }^{3}$ \\ Mary Anna Bogle ${ }^{1}$ \\ ${ }^{1}$ Oak Ridge National Laboratory \\ ${ }^{2}$ Savannah River National Laboratory \\ ${ }^{3}$ Bechtel Jacobs Company LLC
}

March 2011

Prepared for:

U.S. Department of Energy, Office of Environmental Management, Groundwater and Soil Remediation (EM-32) program, Washington, DC

Prepared by:

Environmental Sciences Division

Oak Ridge National Laboratory

P.O. Box 2008, Oak Ridge, TN 37831

Managed by UT-Battelle, LLC

for the Department of Energy under Contract No. DE-AC05-00OR22725

and

The EM Center for Sustainable Groundwater and Soil Solutions

Savannah River National Laboratory

Savannah River Site, Aiken, SC 29808

Managed by Savannah River Nuclear Solutions, LLC

for the Department of Energy under Contract No. DE-AC09-08SR22470 



\section{CONTENTS}

Page

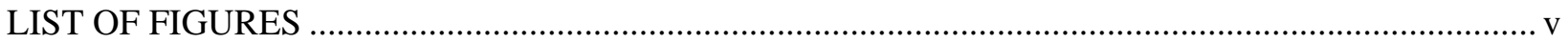

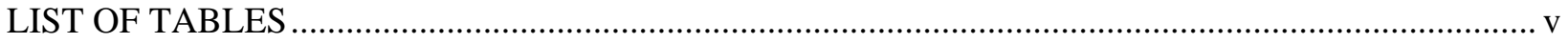

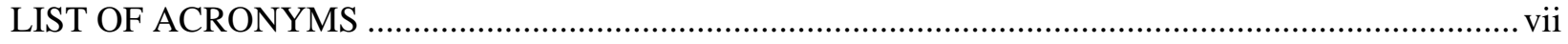

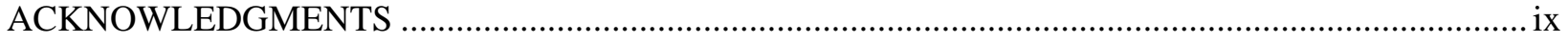

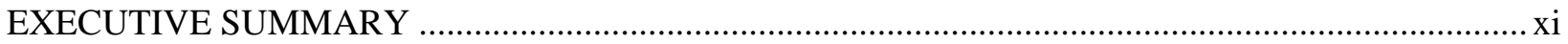

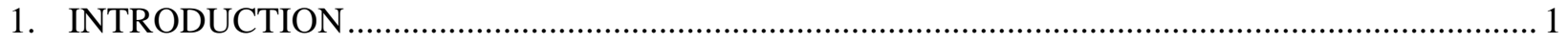

2. MERCURY CONCEPTUAL MODEL DEVELOPMENT IN OAK RIDGE .................................... 3

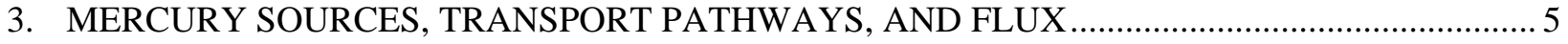

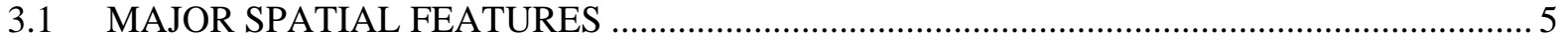

3.2 MAJOR PHYSICAL FEATURES AFFECTING MERCURY PROCESSES AND

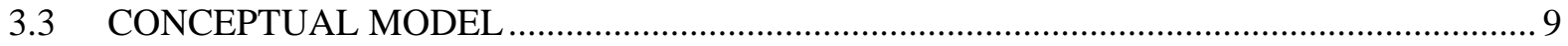

3.3.1 Major Sources and Transport Pathways................................................................... 9

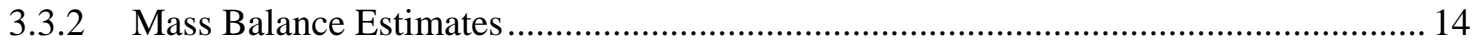

4. DESCRIPTIONS OF MERCURY SOURCE AND TRANSPORT PATHWAYS ............................ 19

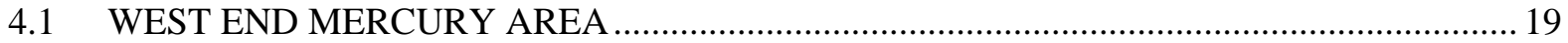

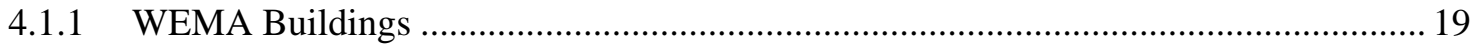

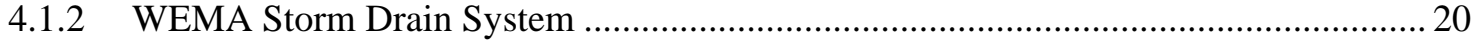

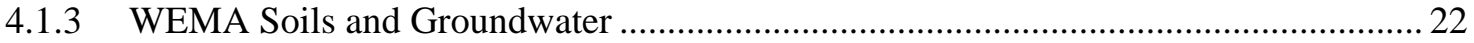

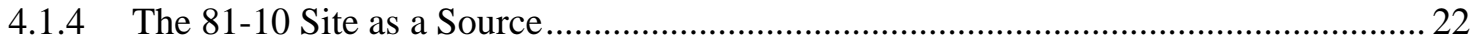

4.1.5 WEMA Surface Soil Erosion and Wet-Weather Export ................................................2

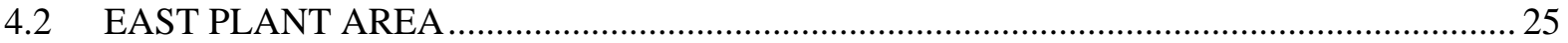

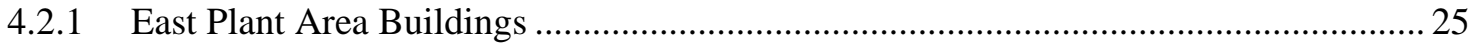

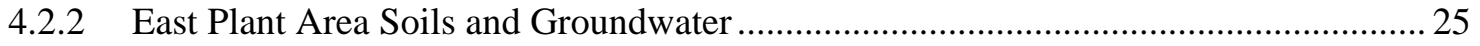

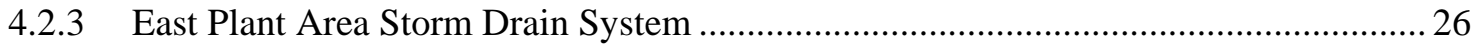

4.2.4 East Plant Area Ungauged Flux ........................................................................... 27

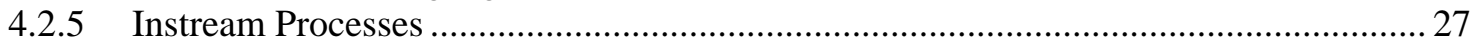

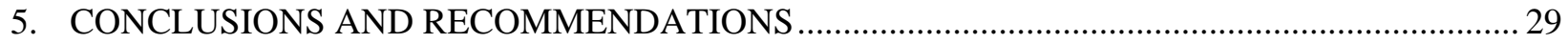

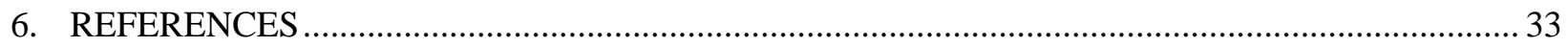

APPENDIX A. COMPENDIUM OF HISTORICAL MERCURY CONCEPTUAL MODELS

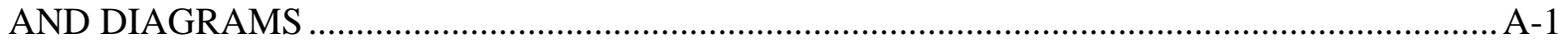

APPENDIX B. TECHNICAL TEAM BIOGRAPHIES ...................................................................... B-1 



\section{LIST OF FIGURES}

Page

Fig. 1. Major historical mercury-use infrastructure (outlined in red), treatments systems, and outfalls within the Y-12 Complex 6

Fig. 2. Major transport pathways for surface water within the Y-12 Complex. Source: Watson and Mueller 2010. 7

Fig. 3. Major physical features affecting mercury processes and transport at the Y-12 Complex.

Fig. 4. Conceptual model for mercury showing primary sources areas, transport pathways, and flux (grams per day) at the Y-12 Complex.

Fig. 5. Estimated mercury fluxes (grams per day) within the WEMA storm drain system based on 2009 WEMA storm drain remediation project sampling (courtesy of D. Lind, Y-12 Complex) and Water Resources Restoration Program sampling in February 2010.

Fig. 6. A soil core in a Lexan liner from the 81-10 site showing visible mercury blobs and droplets.

\section{LIST OF TABLES}

1 Feasibility study assessment (DOE 2000) of anticipated percent remedial effectiveness and flux changes based on estimates of baseline flux and preferred interim source control actions........... 4

2 Supporting flux information for conceptual model of mercury $(\mathrm{Hg})$ sources to surface water at the Y-12 Complex

3 Select flux estimates (grams per day) and mass balance at WEMA drain conduits, Outfall 200, and Station 17, 1980s-2010

4 Contrasting flux (grams/day) at Station 17 and Outfall 200, showing the importance of wetweather events on calculated annual means. 



\section{LIST OF ACRONYMS}

$\begin{array}{ll}\text { ARRA } & \text { American Recovery and Reinvestment Act } \\ \text { BJC } & \text { Bechtel Jacobs Company LLC } \\ \text { BSWTS } & \text { Big Springs Water Treatment System } \\ \text { CERCLA } & \text { Comprehensive Environmental Response, Compensation, and Liability Act } \\ \text { CMTS } & \text { Central Mercury Treatment System } \\ \text { D\&D } & \text { decontamination and decommissioning } \\ \text { DOE } & \text { Department of Energy } \\ \text { EFPC } & \text { East Fork Poplar Creek } \\ \text { EM-32 } & \text { DOE Office of Groundwater and Soil Remediation (formerly EM-22) } \\ \text { FY } & \text { fiscal year } \\ \text { Hg(0) } & \text { elemental mercury } \\ \text { Kd } & \text { partition coefficient between solid and aqueous phases } \\ \text { MIP } & \text { membrane interface probe } \\ \text { NPDES } & \text { National Pollutant Discharge Elimination System } \\ \text { N/S } & \text { north/south } \\ \text { ORNL } & \text { Oak Ridge National Laboratory } \\ \text { OU } & \text { Operable Unit } \\ \text { RA } & \text { remedial action } \\ \text { redox } & \text { oxidation-reduction } \\ \text { RMPE } & \text { Reduction of Mercury in Plant Effluent (Program) } \\ \text { ROD } & \text { Record of Decision } \\ \text { SD } & \text { storm drain } \\ \text { SRNL } & \text { Savannah River National Laboratory } \\ \text { UEFPC } & \text { Upper East Fork Poplar Creek } \\ \text { WEMA } & \text { West End Mercury Area } \\ \text { WRRP } & \text { Water Resources Restoration Program }\end{array}$





\section{ACKNOWLEDGMENTS}

This report was funded by the Department of Energy's (DOE's) Office of Technology Innovation and Development (EM-30) Groundwater and Soil Remediation Program (EM-32). The authors sincerely thank DOE staff members, including Skip Chamberlain, Kurt Gerdes, and Karen Skubal, who saw the need for and value of an updated mercury conceptual model for the Y-12 National Security Complex and provided funding support. Specific guidance regarding programmatic direction was generously given by Karen Skubal in DOE's EM-32 office and Elizabeth Phillips at the DOE Oak Ridge Operations office. The authors would like to acknowledge and thank the many people who have conducted flux investigations at the Y-12 site, as well as those who have developed past conceptual models (including those in Appendix A). The previous modeling work provided a foundation for the current conceptual modeling efforts. The authors wish to thank Mick Wiest and a Y-12 Complex photographer for taking the cover photograph. 



\section{EXECUTIVE SUMMARY}

The interactions between the key processes that control the fate and transport of mercury in the sediments, groundwater, and stream water within the Y-12 National Security Complex in Oak Ridge, Tennessee are extremely complicated, and many aspects are not well understood. In complex environments such as that at the Y-12 Complex, conceptual models are frequently developed to aid in visualization and understanding of the dynamic nature of the hydrologic, geochemical, and physical environment. These conceptual models represent the attempt of scientists to integrate known data in an internally consistent manner to understand processes that control the fate and transport of contaminants. Over the many years of environmental investigation at Y-12, a number of conceptual models have been developed to identify and define various technical processes at a variety of scales. Many of these models have value today as a historical summary of previous modeling efforts and are provided in Appendix A of this report.

The main purpose of the activity described in this report was to develop a conceptual model that delineates the location of mercury sources, transport pathways, and flux based on the most recent data and knowledgeable scientific interpretation. In addition to the conceptual model diagram, the flux numbers and literature sources for the flux estimates are tabularized. Detailed written descriptions of historical and current mercury sources and transport pathways are also provided for both the east and west ends of the facility. The authors believe this conceptual model is a powerful tool for future environmental decision making that will allow the Department of Energy (DOE) to evaluate past and present remedial activities and provide a strong technical basis for prioritizing and optimizing remedial responses in a cost-effective and efficient manner.

Evaluation of the model indicates that the nature and extent of mercury concentration and flux in the Y-12 Complex has significantly changed in the 10 years since conceptual models were used to evaluate the feasibility of implementing interim control actions in the upper East Fork Poplar Creek characterization area. The Big Springs Water Treatment System has effectively reduced mercury inputs to the creek from the Outfall 51 area and has removed greater quantities of mercury from groundwater than was expected. Mercury flux from Outfall 200 at the headwaters of the creek appears to be a greater percentage (70-80\%) of the overall flux leaving the Y-12 Complex compared to a decade ago ( 20\%). The relative role of the four storm drain conduits to Outfall 200 appears to have changed, with Outfall 163 being the greatest contributor to downstream flux. Storm drain remediation actions upstream of Outfall 200 have been initiated, and given the importance of these storm drain transport pathways in contributing mercury to the creek, are well targeted to make a real difference in flux to downstream waters.

This report includes recommendations for improving our conceptual understanding of mercury sources, transport pathways, and flux at the Y-12 site. Important recommendations include development of a better understanding of mercury speciation in the Y-12 soil and groundwater environment; evaluation of transport pathways, particularly near buildings, under storm drains, and in the solution cavity/karst system; evaluation of the importance of mercury concentration versus flux in downstream media and bioavailability; and evaluation of base flow versus storm flow flux. Understanding the relative role of various sources requires continued assessment of transport pathways under base flow and storm flow conditions at multiple sites at the same time.

Recent facility and security reconfiguration efforts, site characterization, remedial actions, and research are facilitating the collection of new mercury data at Y-12. The conceptual model provided herein takes advantage of the extensive recent mercury sampling to provide an updated assessment of mercury mass balance and support a refined understanding of mercury behavior in or near Y-12. It is hoped that this assessment will assist in future environmental management decisions and in mitigating the impacts of mercury on the surrounding environment. 



\section{INTRODUCTION}

Releases of mercury during operations at the Y-12 National Security Complex during the 1950s and early 1960s resulted in contamination of soil and groundwater within the facility, and subsequent transport from these sources resulted in contamination of East Fork Poplar Creek (EFPC). Remediation efforts, which began in the 1980s, have reduced waterborne mercury concentrations both within the Y-12 facility and in the EFPC ecosystem, but elevated levels of mercury remain in the soil, sediment, water, and biota. The processes that control the fate and transport of mercury near the facility are extremely complex, and the hydrological, geochemical, and microbial interactions between the subsurface and surface water systems are not well understood. The Department of Energy (DOE) has significant concerns that, although planned future remedial actions and decontamination and decommissioning (D\&D) activities should substantially reduce mercury flux to the creek in the long term, remediation and construction activities during D\&D could induce changes in subsurface flow paths that might result in unintended short-term releases to downstream waters. In addition, mercury characterization activities at Y-12 in the recent past have not been comprehensive, concurrent, or systems-based and were typically site-specific efforts conducted over a short period of time. A reevaluation of mercury source areas, processes, likely flow paths, and flux into the creek at Y-12 is needed for effective environmental management and site closure decision making relative to mercury contamination.

A technical workshop funded by the DOE Office of Groundwater and Soil Remediation (EM-32, formerly EM-22) was held at the Oak Ridge National Laboratory (ORNL) in January 2008. The focus of this workshop was to identify technical uncertainties relative to the characterization and remediation of mercury within the Y-12 Complex, Upper East Fork Popular Creek (UEFPC), and downstream drainages (Looney et al. 2008). As part of the workshop, a generalized conceptual model for distribution of mercury contamination associated with activities within the Y-12 and UEFPC system was developed (Appendix A). A technical team identified four logical subdomains based on one or more characteristics that specifically relate to scientific challenges or environmental management opportunities. The four subdomains identified in the review were

- Domain I: Building/Rubble,

- Domain II: Source Zone Soil,

- Domain III: Outfall 200 Area, and

- Domain IV: Upper and Lower Reaches of Upper East Fork Poplar Creek.

Each of these domains was evaluated by the team to identify technical uncertainties and environmental management opportunities. The primary focus of the team was on scientific challenges and processes active in Domains III and IV—specifically, the challenges and processes associated with the complex chemical transformations of mercury that occur after water from different sources in the process area is added to UEFPC and moves downgradient through the watershed. Several specific recommendations for follow-up research were used to select "Quick Win" projects that were funded by EM-22 (later EM-32) and subsequently successfully conducted by ORNL. The research focused on mercury-reduction treatment options at Outfall 200 (Domain III) and changes in flow augmentation to limit stream sediment mercury release (Domain IV) (Southworth et al. 2009; Southworth et al. 2010a).

The major objective of this report is to improve understanding of the location and nature of residual mercury sources and transport pathways from Domain I and II areas to the outfalls and stream (Domains III and IV). This work builds on the generalized conceptual model developed during the 2008 workshop, as well as numerous previous efforts to delineate and understand the mercury source and transport pathways at Y-12. As a means of better understanding the evolving nature of the mercury issue in Oak Ridge, a brief history of mercury conceptual model development in Oak Ridge is summarized in this 
report, and graphical representations completed in previous studies are included in Appendix A. Most importantly, new data are available from recent site characterizations, remedial action performance sampling, and research at the Y-12 Complex that can be used to refine the current conceptual model. Using both historical and recent data, the conceptual model provides an evaluation of mercury mass balance and supports a refined understanding of mercury behavior in or near Y-12 to assist in environmental management decisions and in mitigating the impacts of mercury on the surrounding environment. 


\section{MERCURY CONCEPTUAL MODEL DEVELOPMENT IN OAK RIDGE}

Conceptual models are diagrams or narrative descriptions used to inform decision makers as well as the public and are often used in environmental management (Suter 1999). Such models can help focus stakeholders on the key processes and elements important to effective decision making and influence future monitoring, prioritization of further remedial actions, numerical modeling efforts, and decisions concerning the need for further research. Importantly, conceptual models can provide clarity in understanding limited or complex data and can help convey uncertainty and data gaps.

Conceptual models have long been used as a way to visualize and understand the complex mercury processes at the Y-12 Complex. A compendium of historical conceptual models and diagrams used to describe the mercury situation at Y-12 and/or in EFPC is provided in Appendix A. The compendium illustrates the changes in conceptual model development over time in Oak Ridge, and the wide range of model types. Conceptual models used to describe mercury processes at the Y-12 Complex and EFPC include those describing instream mercury processes, physical features at the Y-12 Complex (e.g., buildings and subsurface characteristics), and mercury sources and transport pathways. Conceptual models have been highly variable in presentation depending in part on the model's goals and objectives, the intended audience, and the level of detail or complexity needed. Unlike numerical models, conceptual models must balance the need to capture complex processes with the potential problem of adding too much complexity and losing the key messages the model is trying to convey. The model for scientists, engineers, and simulation modelers may be very different from that needed to convey key concepts to program managers, public stakeholders, or regulators (Gentile et al. 2001). The focus of the most recent conceptual modeling effort is to convey key concepts to the latter group, using a mercury-source-and-transport-pathway type of model. The model uses a spatially explicit depiction to evaluate the relative magnitude of mercury flux and overall mass balance.

Such a flux model was used for the feasibility study in upper EFPC which helped define the flux status (using data up to the year 2000) and the potential mercury concentration and flux reductions associated with various source control actions (Table 1). It has been 10 years since conceptual models were used to evaluate mercury flux and the potential reductions associated with source control actions. Some of the underlying assumptions that went into the Record of Decision (ROD) have changed. Probably the most important finding in the last 10 years has been that the expected responsiveness of fish to reductions of waterborne mercury has not been realized (Peterson et al. 2009). In UEFPC in the 1990s, mercury in fish declined at a rate similar to the decrease in waterborne mercury concentration at Station 17 . That correspondence was consistent with a key assumption of remedial strategies at the site: that mercury accumulation in fish in EFPC was proportional to waterborne total mercury (Energy Systems 1999). This assumption was the basis for derivation of the $200 \mathrm{ng} / \mathrm{L}$ aqueous mercury target (a human health recreational risk-based level) guiding Comprehensive Environmental Response, Compensation, and Liability Act (CERCLA) efforts in UEFPC. The lack of response in fish over the last 10 years is an underlying driver for numerous new mercury-related programs, initiatives, and evaluations, including the Total Maximum Daily Load Mercury Working Group, the EM-32 Technical Assistance Team efforts and follow-on mercury research, and various CERCLA early actions conducted as part of American Recovery 
Table 1. Feasibility study assessment (DOE 2000) of anticipated percent remedial effectiveness and flux changes based on estimates of baseline flux and preferred interim source control actions

\begin{tabular}{|l|c|l|c|c|}
\hline & \multirow{2}{*}{$\begin{array}{c}\text { Percent } \\
\text { Base flow source } \\
\text { area }\end{array}$} & $\begin{array}{c}\text { reduction } \\
\text { assumed }\end{array}$ & \multicolumn{1}{c|}{ Rationale } & \multicolumn{2}{c|}{$\begin{array}{c}\text { Estimated mercury flux } \\
\text { (g/d) }\end{array}$} \\
\cline { 3 - 5 } & 0 & $\begin{array}{l}\text { Coincidental excavation of mercury- } \\
\text { contaminated Salvage Yard soils } \\
\text { impact unknown }\end{array}$ & 0.09 & 0.09 \\
Salvage Yard & 50 & $\begin{array}{l}\text { Hydraulic isolation: sewer relining } \\
\text { and capping actions }\end{array}$ & 1.8 & 0.9 \\
\hline $\begin{array}{l}\text { Outfalls 169, 163, } \\
160,150\end{array}$ & 0 & Impact of planned actions unknown & 0.4 & 0.4 \\
\hline $\begin{array}{l}\text { N/S pipe, } \\
\text { ungauged }\end{array}$ & 70 & Sediment removal & 4.5 & 1.4 \\
\hline $\begin{array}{l}\text { Station 8, } \\
\text { ungauged }\end{array}$ & 95 & Effectiveness of Bldg.9201-2 WTS & 2.5 & 0.1 \\
\hline Outfall 51/55 & 100 & $\begin{array}{l}\text { Lake Reality bypass assumed to } \\
\text { continue; UEFPC sediment } \\
\text { contribution eliminated by removal }\end{array}$ & 1.4 & 0 \\
\hline $\begin{array}{l}\text { Station 17, } \\
\text { ungauged }\end{array}$ & - & $\begin{array}{l}\text { In-stream-NPDES monitoring } \\
\text { location }\end{array}$ & 11.2 & $(330 \mathrm{ppt})$ \\
\hline Station 17 & & & 3.3 \\
\hline
\end{tabular}

NPDES = National Pollutant Discharge Elimination System

$\mathrm{N} / \mathrm{S}=$ north/south

ppt $=$ parts per trillion

UEFPC $=$ Upper East Fork Poplar Creek

WTS $=$ water treatment system

and Reinvestment Act (ARRA) initiatives.

In addition to changes in bioaccumulation patterns, mercury concentration and flux have also changed in UEFPC and various outfalls since the ROD baseline assessments 10 years ago. Aqueous mercury levels in the creek have decreased in part due to successful control actions such as treatment of the old Outfall 51 discharge by the Big Springs Water Treatment System (BSWTS). In other cases the flux numbers associated with some source areas appear to have increased, or more information is known today about source area flux. The influence of stream sediment mercury sources upstream of Outfall 109 is better understood today, as is storm flow flux, although sediment and other ungauged sources of mercury to the creek remain a major area of investigation.

The conceptual model developed for this report is a source-and-transport-pathway type of model that evaluates the role of source areas and provides estimates of mercury flux generated from a number of recent investigations. New data sources used for the conceptual model and supporting text in this report include a 2007 synoptic survey by ORNL staff (Southworth et al. 2007), EM-32 studies of the role of sediment and flow management in 2008 and 2009 (Southworth et al. 2009; Southworth et al. 2010a), Bechtel Jacobs Company LLC (BJC) Water Resources Restoration Program (WRRP) data in 2009 and 2010 (DOE 2010a; DOE 2011), West End Mercury Area (WEMA) storm drain surveys in 2009 as part of ARRA investigations (DOE 2010b; Lind 2009), and soil mercury investigations in 2010 at 81-10 (ORISE 2010) and near the Alpha 2 building (ORNL sampling unpublished). 


\section{MERCURY SOURCES, TRANSPORT PATHWAYS, AND FLUX}

ORNL and Savannah River National Laboratory (SRNL) staff working for DOE's EM-32 program met for 3 days in June 2009 to develop an updated conceptual model of mercury flux at the Y-12 site. Most of the team discussion focused on reviewing existing conceptual models from a variety of sources and then consolidating the information. A previously used model was refined and developed to reflect the current understanding of processes at the site (see Appendix A).

The ORNL and SRNL team used the following structured process to develop the conceptual model:

1. define the goals and objectives;

2. delineate the spatial and temporal scales and boundaries for the model;

3. discuss sources of information, data, current knowledge, and existing conceptual models;

4. describe both primary and secondary sources of mercury;

5. identify the primary and secondary diffuse sources of mercury;

6. describe mechanisms, flow paths, and routes of exposure;

7. develop and refine the graphic conceptual model; and

8. identify technical uncertainties and opportunities for further work.

The goal was to create some relatively simple diagrams that would help people better understand the mercury processes and mass balance situation at Y-12 and would assist in effective environmental management decision making. Useful diagrams provided herein include spatially explicit maps showing the major mercury-use buildings, outfalls, treatment systems, and transport pathways (Sect. 3.1); a schematic of the Y-12 Complex's physical features that affect mercury processes and transport (Sect. 3.2); and the most recently developed conceptual model of mercury sources, transport pathways, and flux (Sect. 3.3).

\subsection{MAJOR SPATIAL FEATURES}

The Y-12 Complex is an industrial facility that has been in operation since the 1940s and consists of buildings and infrastructure located in a valley. Significant quantities of mercury have been released from the Y-12 facilities into the environment, including an estimated 193,000 $\mathrm{kg}$ to soil, and 128,000 $\mathrm{kg}$ to EFPC by 1963 (ChemRisk 1999; Brooks amd Southworth 2011). The major mercury-use buildings, outfalls, and mercury-treatment systems found within the western and eastern areas of the facility are shown in Fig. 1 (mercury-use buildings highlighted in red). The mercury-contaminated infrastructure at the facility is designated along with current and planned major D\&D activities and remedial actions at the facility. This simple map provides a basic geospatial understanding of the mercury-use areas, buildings, and contamination zones within the context and proximity of transport pathways, outfalls, and downstream locations. The importance of transport pathways for moving mercury from high-use areas to downstream waters is illustrated in Fig. 2 (Watson and Mueller 2010; created using geographic information system technology [ARCGIS 9.2]). Transport pathways may include historical stream and tributary channels, overland flow, process discharges, storm drains, and diffuse subsurface channels. The conceptual modeling effort for this report coupled the basic spatial locations of facility infrastructure and flow paths with the best available mercury flux results (Sect. 3.3). 


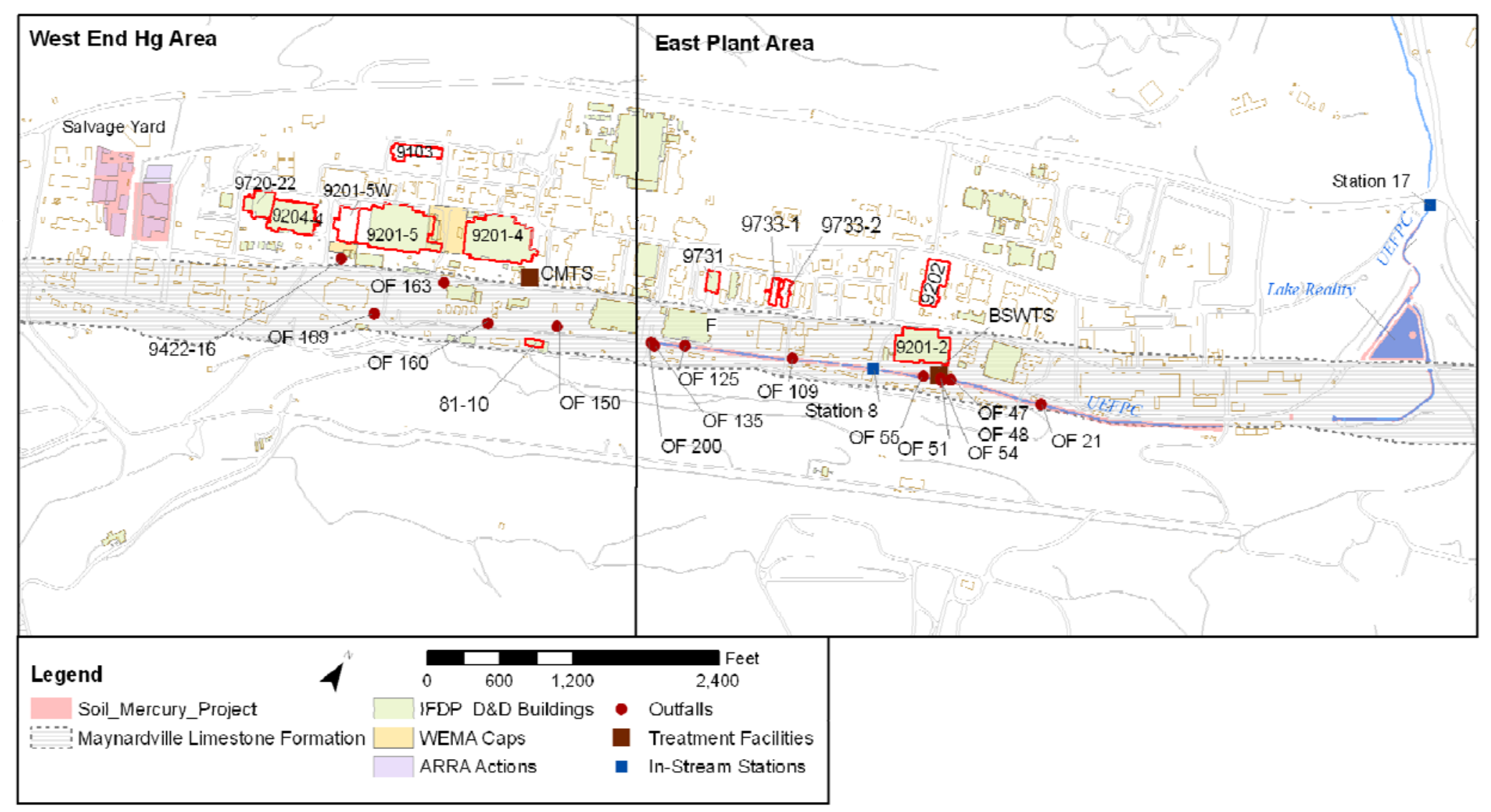

Fig. 1. Major historical mercury-use infrastructure (outlined in red), treatment systems, and outfalls within the Y-12 Complex. 


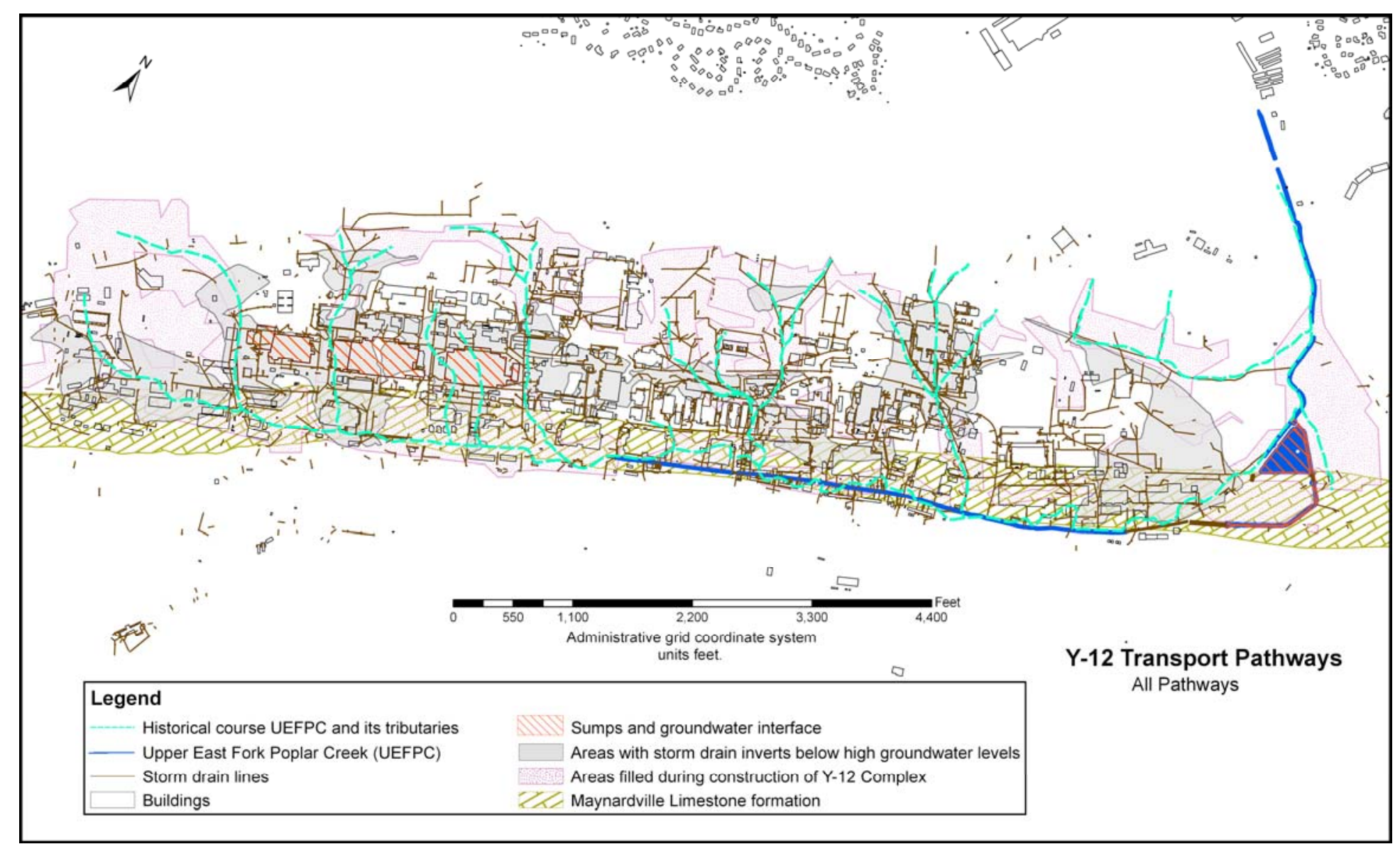

Fig. 2. Major transport pathways for surface water within the Y-12 Complex. Source: Watson and Mueller 2010. 


\subsection{MAJOR PHYSICAL FEATURES AFFECTING MERCURY PROCESSES AND TRANSPORT}

A simplified graphic showing the major physical features affecting mercury processes and transport at the Y-12 Complex is provided in Fig. 3. The graphic depicts key features of subsurface physical structure and contaminant transport-release pathways within the Y-12 Complex and UEFPC area. The subsurface beneath the Y-12 Complex consists of a layer of unconsolidated saprolite or fill overlying fractured and folded bedrock formations of shale and limestone that characterize the geology of the regional ridge and valley topography. The thickness of the unconsolidated material varies from a few feet to nearly $30 \mathrm{ft}$ in the north-central area of the complex. Most facilities in WEMA are located on the low-permeability Nolichucky Shale formations, while the 81-10 site and part of 9201-2 lie on the much more permeable and karstic Maynardville Limestone. The groundwater level ranges from less than 5 to $10 \mathrm{ft}$ below the surface near UEFPC to more than 30 to $40 \mathrm{ft}$ below the surface in upland areas. Basement sumps in 9201-4 and 9201-2 pull in groundwater from the immediate area surrounding process buildings. These sumps historically fed groundwater into the storm drain system but have been rerouted to water treatment facilities. Sumps at 9201-5 are no longer in operation, allowing groundwater to accumulate in the basement of the building.

Contamination is introduced into groundwater through multiple paths including historical spills, pipeline leaks, and dissolution from contaminated soils and sediments. Due in part to the nonwetting properties and high density of liquid mercury, spills and leaks of mercury at the surface or within buildings may result in deposits of subsurface liquid mercury in both the unconsolidated and bedrock systems. Such deposits can provide a long-term source of mercury contamination in the groundwater that feeds the UEFPC, as evidenced by the presence of mercury from Outfall 51, which drains a large spring adjacent to 9201-2.

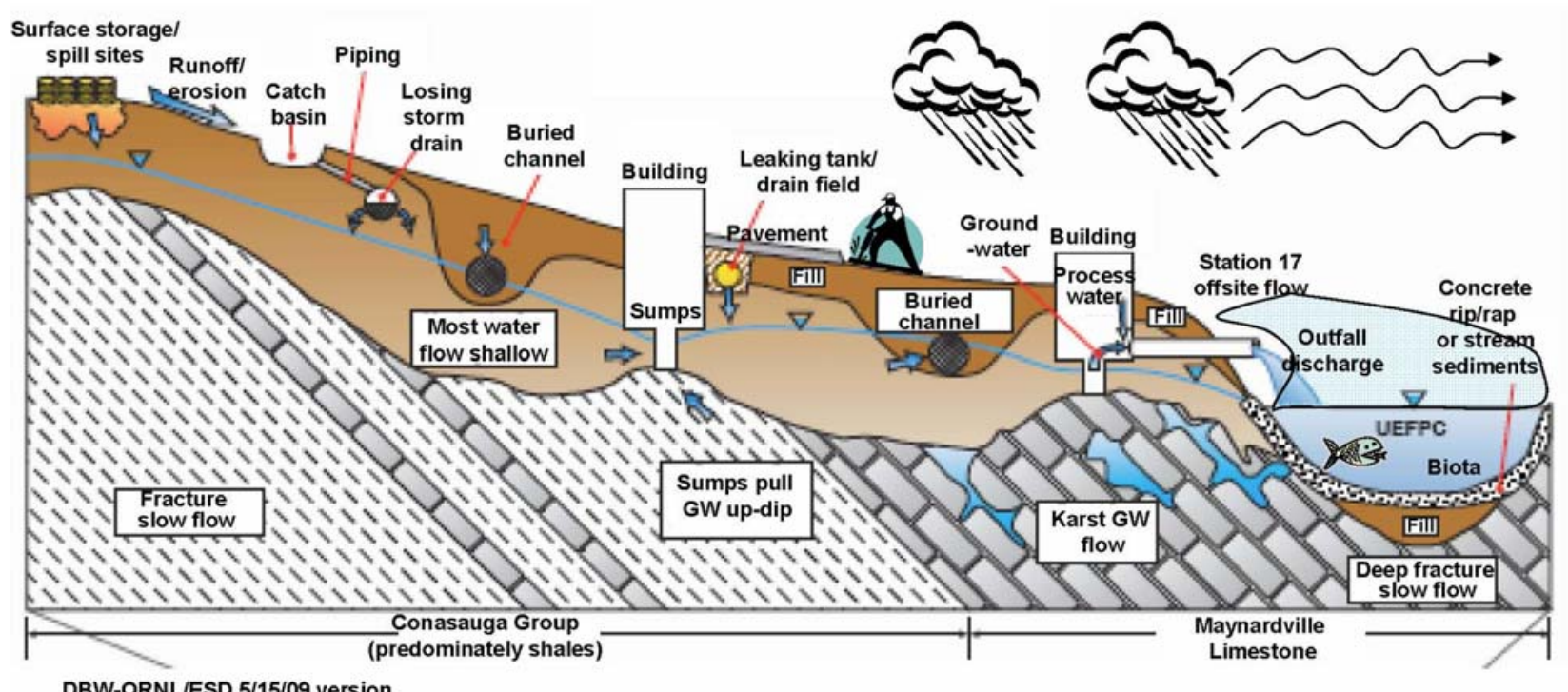

Fig. 3. Major physical features affecting mercury processes and transport at the Y-12 Complex. 


\subsection{CONCEPTUAL MODEL}

Our understanding of the role of mercury sources and flux at the Y12 Complex is constantly evolving. In July 2009, draft versions of a Y-12 Complex mercury conceptual model prepared during the early stages of this project were shared with the DOE Oak Ridge technology development team working on mercury remediation strategies. The 2009 draft conceptual model is further refined here, both through a new conceptual model diagram and accompanying data, analysis, and interpretation. This most recent conceptual model incorporates FY 2010 WEMA sampling results reported in DOE 2011, and updated BSWTS influent flux data from the Water Resources Restoration Program. An accompanying figure includes results from the WEMA storm drain project in 2009. A comprehensive, contemporaneous sampling of storm drains and transport pathways throughout the Y-12 Complex and UEFPC does not exist; therefore, the model, by necessity, uses sampling results from different years, often collected and analyzed using different

\section{Key Point:}

Understanding mercury

releases under both base flow

and storm flow conditions as

well as how past mercury

actions have impacted these

releases are keys to

developing sound mercury

mitigation strategies in the

future. A meta-analysis of

historical and recent data

supports development of a

conceptual model that captures

and addresses these important

issues.

methods and sampled during varied flow regimes. Data used to prepare the model represent the most recent flux data when available, but other supporting data were preferentially selected if they averaged over longer time periods. As a result the model represents an average flux during both base flow and storm flow conditions.

\subsubsection{Major Sources and Transport Pathways}

Figure 4 consolidates knowledge about mercury sources at the Y-12 Complex and provides summary information on the transport of mercury through the system, including the approximate magnitude of flux. The data sources that provide the basis of the model are provided in Table 2. In the conceptual model depiction, the bulk of the mercury mass is present in a variety of potential primary source locations. Over time mercury is released from these primary sources via physical (e.g., diffusion and advection) or chemical (e.g., oxidation and complexation) processes. This mercury can enter one of the transport pathways (which may also contain metallic mercury acting as a primary source) and is subject to migration and potential discharge to the surrounding environment and potential on-site and off-site receptors. The primary sources, depicted in yellow on Fig. 4, each represent a "reservoir" of elemental mercury and/or particle-bound mercury and have historical linkages to a known release. Such primary source areas include the storm drain system, the solution cavity (karst) system, streambed sediments, buildings, sumps, footers, process pipes, tanks, and mercury nonaqueous-phase liquid collection zones in the subsurface. Note that some of these reservoirs are at or near the original release locations and some are distributed along transport paths (e.g., metallic mercury in solution cavities and storm drains). Figure 4 also provides information about the spatial connection of the identified sources and transport pathways (including building and outfall designations) to provide actionable information for the teams developing remediation priorities and plans for facility disposition and reconfiguration.

This more detailed and more nuanced information is key to supporting environmental management and assisting in prioritizing and deprioritizing potential activities. For example, the major fluxes associated with WEMA are clearly depicted and represent an important priority-in particular the residual-source mercury within and adjacent to the storm drain system and in conduits connecting the storm drains to contaminated buildings. This information strongly supports early actions (e.g., drain visualization and characterization) that have been selected and implemented at WEMA to address these residual sources. Conversely, the fluxes from facilities in the East Plant Area are relatively low. A graded approach in which the emphasis on, and complexity of, actions associated with the East Plant Area facilities is 


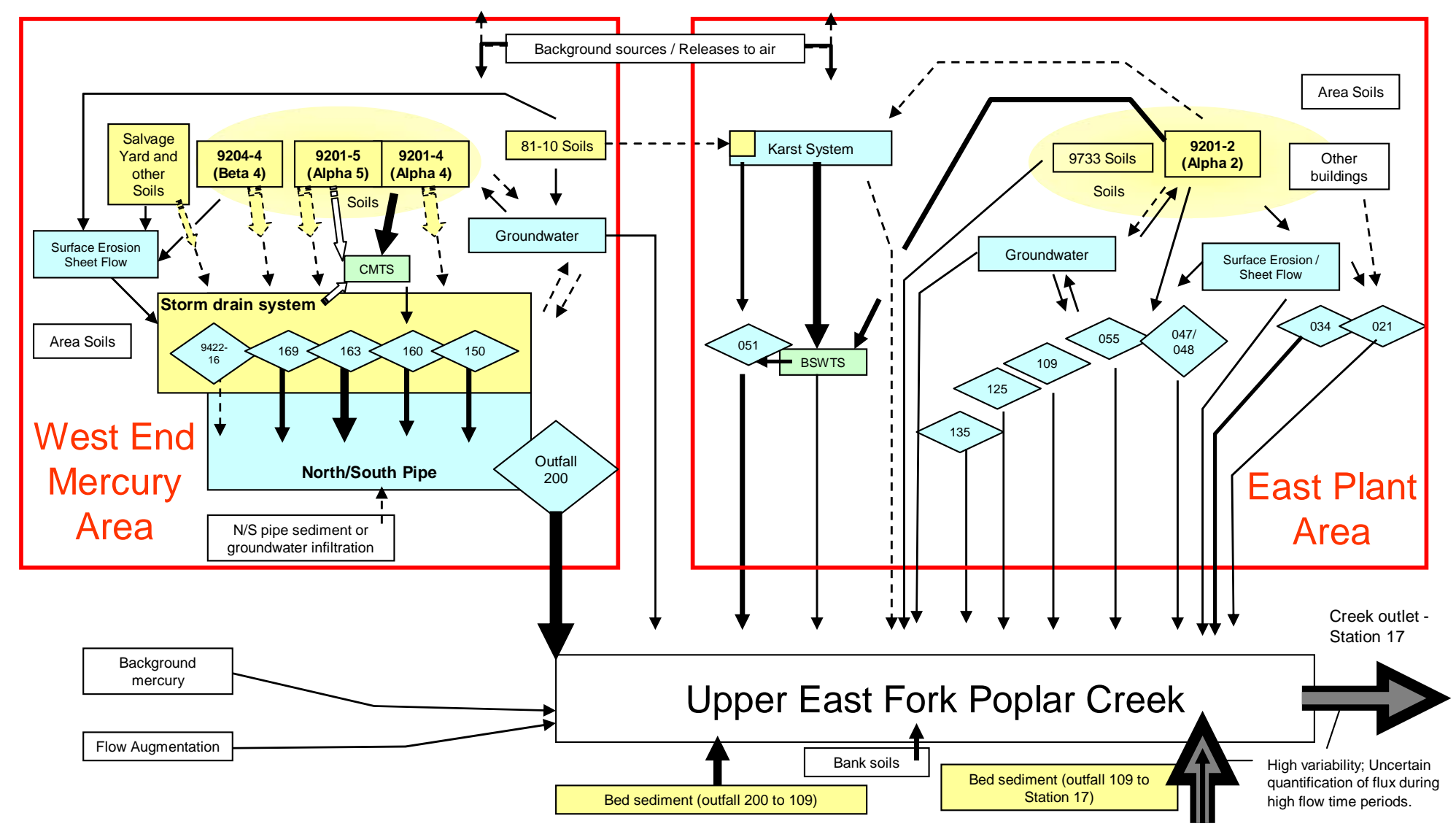

\begin{tabular}{|c|c|c|c|c|}
\hline $\begin{array}{l}\text { Y-12 Mercury Conceptual Model } \\
\text { Title: Conceptual model for mercury showing } \\
\text { primary source areas, transport pathways, and } \\
\text { flux (grams/day) at the Y-12 Complex. } \\
\text { Model Version: 03/09/2011. } \\
{ }^{1} \text { To the extent possible, longer-term average fluxes } \\
\text { used in model, reflecting dry and wet weather } \\
\text { conditions. }\end{array}$ & Legend & $\begin{array}{l}\text { Primary Source Areas } \\
\text { Secondary Source Areas } \\
\text { Transport paths } \\
\text { (sampling locations) } \\
\text { Treatment systems } \\
\text { refer to SD outfalls, basins }\end{array}$ & $\begin{array}{l}\text { ms/day }{ }^{1} \\
15-25 \\
6-15 \\
2-6\end{array}$ & 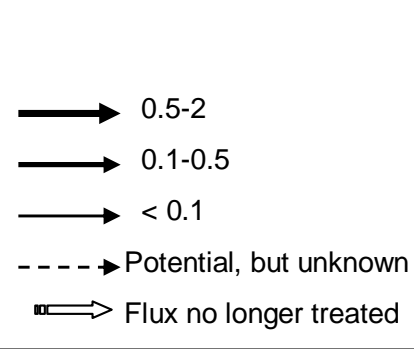 \\
\hline
\end{tabular}

Fig. 4. Conceptual model for mercury showing primary sources areas, transport pathways, and flux (grams per day) at the Y-12 Complex. 
Table 2. Supporting flux information for conceptual model of mercury $(\mathrm{Hg})$ sources to surface water at the Y-12 Complex

\begin{tabular}{|c|c|c|c|}
\hline Transport paths & Flux (g/d) & Data sources & Explanatory comments \\
\hline \multicolumn{4}{|c|}{ WEST END MERCURY AREA } \\
\hline $\begin{array}{l}\text { Surface erosion/sheet flow } \\
\text { from } 81-10 \text { site }\end{array}$ & $<0.1$ & \begin{tabular}{|l} 
Energy Systems \\
1996 \\
\end{tabular} & Limited exposed soil. \\
\hline $\begin{array}{l}\text { 81-10 source to shallow } \\
\text { groundwater; entered old } \\
\text { N/S pipe }\end{array}$ & $<0.1$ & $\begin{array}{l}\text { Bogle and } \\
\text { Southworth } 1998\end{array}$ & $\begin{array}{l}\text { Water within old N/S pipe } \sim 7 \mu \mathrm{g} / \mathrm{L} \text {, trickled } \\
\text { into Outfall } 200 .\end{array}$ \\
\hline 81-10 to karst system & Unknown & $\begin{array}{l}\text { Rothschild et al. } \\
1984\end{array}$ & $\begin{array}{l}\text { High Hg in soil above water table at } 81-10 \text { and } \\
\text { location over limestone bedrock makes this a } \\
\text { likely source of Hg in karst system; however, } \\
\text { no definitive link has been demonstrated to } \\
\text { creek or Outfall } 51 .\end{array}$ \\
\hline $\begin{array}{l}\text { Migration of metallic Hg } \\
\text { from soil or building drains } \\
\text { to storm drain system }\end{array}$ & Unknown & $\begin{array}{l}\text { DOE 2010a; DOE } \\
2011\end{array}$ & $\begin{array}{l}\text { Metallic Hg was seen in storm drain systems } \\
\text { as part of WEMA video investigations, and is } \\
\text { occasionally removed from catch basins. } \\
\text { Observed through grate in Outfall } 150 .\end{array}$ \\
\hline WEMA surface erosion & $<0.1$ & $\begin{array}{l}\text { Energy Systems } \\
1996,1997\end{array}$ & Wet weather only. \\
\hline $\begin{array}{l}\text { WEMA buildings to } \\
\text { groundwater }\end{array}$ & $<0.1$ & $\begin{array}{l}\text { Rothschild et al. } \\
1984\end{array}$ & $\begin{array}{l}\text { Sump pumping drives shallow groundwater } \\
\text { flow into buildings, not out. With } \\
\text { discontinuation of sumps in 9201-5, the } \\
\text { building may now contribute to shallow } \\
\text { groundwater. }\end{array}$ \\
\hline $\begin{array}{l}\text { Shallow groundwater to } \\
\text { storm drain system }\end{array}$ & $<0.1$ & $\begin{array}{l}\text { Rothschild et al. } \\
1984\end{array}$ & $\begin{array}{l}\text { Shallow groundwater Hg not clearly } \\
\text { identified. Limited characterization suggests } \\
\text { Hg concentrations in groundwater lower than } \\
\text { in storm drains. }\end{array}$ \\
\hline $\begin{array}{l}\text { Sump water treated at } \\
\text { CMTS }\end{array}$ & 2 & $\begin{array}{l}\text { Energy Systems } \\
1996,1997\end{array}$ & $\begin{array}{l}\text { 9201-4 sump water treated at CMTS; } 2 \text { to } 3 \text { g } \\
\text { from 9201-5 and EM3250 catch basin tie-in } \\
\text { no longer treated. }\end{array}$ \\
\hline CMTS discharge & $<0.01$ & DOE 2010a & \\
\hline $\begin{array}{l}\text { West end storm drains } \\
\text { including Old Salvage } \\
\text { Yard }\end{array}$ & $<0.1$ & $\begin{array}{l}\text { Energy Systems } \\
\text { 1997; DOE 2000; } \\
\text { Southworth et al. } \\
2007\end{array}$ & $\begin{array}{l}\text { Demonstrated very low loading from far } \\
\text { western part of Y-12 based on sampling points } \\
9422-16 \text { and } 169 \mathrm{~W} \text { just upstream of N/S pipe. }\end{array}$ \\
\hline Outfall 169 & 1.4 & DOE 2011 & Mean of weekly averages, January-Sep 2010. \\
\hline Outfall 163 & 5.5 & DOE 2011 & Mean of weekly averages, January-Sep 2010. \\
\hline Outfall 160 & 0.6 & DOE 2011 & Mean of weekly averages, January-Sep 2010. \\
\hline Outfall 150 & 1.4 & DOE 2011 & Mean of weekly averages, January-Sep 2010. \\
\hline $\begin{array}{l}\text { Outfall } 200 \text { (N/S pipe } \\
\text { terminus; sampling is at } \\
\text { 200A6) }\end{array}$ & $8.6(25.6)$ & DOE 2011 & $\begin{array}{l}\text { Surface water exit for all WEMA Hg. Mean of } \\
\text { weekly averages, January-Sep 2010, } 8.6 \text { g/d. } \\
\text { FY 2010: } 25.6 \text { g/d. } 2007 \text { synoptic study at } \\
\text { base flow was 5.2 g/d; FIU calculation of } \\
\text { OREIS data [2004-2008] was } 6.4 \text { g/d. } \\
\end{array}$ \\
\hline $\begin{array}{l}\text { Sediment or groundwater } \\
\text { into N/S pipe }\end{array}$ & Unknown & & $\begin{array}{l}\text { No direct measurements, but not thought to be } \\
\text { a major source }\end{array}$ \\
\hline $\begin{array}{l}\text { Shallow groundwater } \\
\text { infiltration to EFPC }\end{array}$ & $<0.1$ & $\begin{array}{l}\text { Rothschild et al. } \\
1984\end{array}$ & $\begin{array}{l}\text { Limited evidence of any major shallow } \\
\text { groundwater Hg, with historical sampling } \\
\text { finding Hg concentrations in groundwater } \\
\text { lower than in EFPC. Evaluation of potential } \\
\text { source to creek through preferential pathways } \\
\text { a research need. }\end{array}$ \\
\hline
\end{tabular}


Table 2. continued

\begin{tabular}{|c|c|c|c|}
\hline Transport paths & Flux (g/d) & Data sources & Explanatory comments \\
\hline \multicolumn{4}{|l|}{ EAST PLANT AREA } \\
\hline Atmospheric deposition & 0.12 & MDN 2007 & \\
\hline Outfall 51 & $0.2-2.0$ & $\begin{array}{l}\text { DOE 2001, DOE } \\
\text { 2010a DOE } 2011\end{array}$ & $\begin{array}{l}\text { Average in FY } 20100.9 \mathrm{~g} / \mathrm{d}, 2-3 \text { times higher } \\
\text { than the average in recent previous years - } \\
\text { likely associated with BSWTS bypass during } \\
\text { high flow events and greater annual } \\
\text { precipitation. Historically contained strong } \\
\text { dissolved elemental Hg signal, potentially } \\
\text { linked to subsurface metallic Hg in limestone } \\
\text { solution cavity network upstream (81-10 or } \\
\text { under N/S pipe). }\end{array}$ \\
\hline $\begin{array}{l}\text { Input to BSWTS from karst } \\
\text { system }\end{array}$ & $2-8$ & $\begin{array}{l}\text { DOE 2011; BSWTS } \\
\text { data }\end{array}$ & $\begin{array}{l}\text { Based on monthly grab and weekly flow } \\
\text { estimates, high flux to treatment system } \\
\text { observed during first three years of BSWTS } \\
\text { operation (max } 97.7 \text { g/d; max annual average } \\
\text { in } 200722 \text { g/d). Suggests that BSWTS treated } \\
\text { particulate Hg that previously did not get to } \\
\text { EFPC. Average last } 3 \text { years (2008-2010) was } \\
6 \text { g/d, with only } 2 \text { g/d in FY } 2010 .\end{array}$ \\
\hline 9201-2 to karst system & Unknown & & $\begin{array}{l}9201-2 \text { is site of soil contamination with } \\
\text { metallic Hg, but groundwater flow is into } \\
\text { basement, not out. Possible metallic Hg within } \\
\text { old Outfall } 51 \text { spring throat, nearby solution } \\
\text { cavities. }\end{array}$ \\
\hline BSWTS discharge & 0.07 & DOE 2010a & \\
\hline 9201-2 sumps to BSWTS & 1 & $\begin{array}{l}\text { Energy Systems } \\
1996\end{array}$ & \\
\hline $\begin{array}{l}\text { Undetected karst discharge } \\
\text { to EFPC }\end{array}$ & Unknown & $\begin{array}{l}\text { Southworth et al. } \\
2007\end{array}$ & Not known. Research need. \\
\hline $\begin{array}{l}9733 \text { soils to storm drains } \\
\text { or creek }\end{array}$ & $<0.03$ & $\begin{array}{l}\text { Southworth et al. } \\
2007\end{array}$ & Remediated site. \\
\hline $\begin{array}{l}\text { Shallow groundwater } \\
\text { infiltration to EFPC }\end{array}$ & $<0.1$ & $\begin{array}{l}\text { Rothschild et al. } \\
1984\end{array}$ & $\begin{array}{l}\text { No known major inputs. Evaluation of } \\
\text { potential source to creek preferential pathways } \\
\text { a research need. }\end{array}$ \\
\hline $\begin{array}{l}\text { Shallow groundwater to } \\
\text { storm drain system }\end{array}$ & $<0.1$ & $\begin{array}{l}\text { Rothschild et al. } \\
1984\end{array}$ & $\begin{array}{l}\text { No evidence of shallow groundwater entering } \\
\text { storm drain system. }\end{array}$ \\
\hline Outfall 135 & 0.05 & $\begin{array}{l}\text { Southworth et al. } \\
2007\end{array}$ & $\begin{array}{l}\text { Detected but at low levels (likely storm drain } \\
\text { contamination). }\end{array}$ \\
\hline Outfall 125 & 0.08 & $\begin{array}{l}\text { Southworth et al. } \\
2007\end{array}$ & $\begin{array}{l}\text { Detected but at low levels (likely storm drain } \\
\text { contamination). }\end{array}$ \\
\hline Outfall 109 & 0.03 & $\begin{array}{l}\text { Southworth et al. } \\
2007\end{array}$ & Drains 9733 site. \\
\hline Outfall 55 & $<0.01$ & $\begin{array}{l}\text { Southworth et al. } \\
2007\end{array}$ & Extremely low flow. \\
\hline Outfall $47 / 48$ & 0.08 & $\begin{array}{l}\text { Southworth et al. } \\
2007\end{array}$ & $\begin{array}{l}\text { Detected but at low levels (likely storm drain } \\
\text { contamination). }\end{array}$ \\
\hline 9201-2 to groundwater & $<0.1$ & $\begin{array}{l}\text { Henke, Bogle, and } \\
\text { Turner } 1996\end{array}$ & $\begin{array}{l}\text { Groundwater under 9201-2 flows into sumps; } \\
\text { however, unclear whether nearby Hg- } \\
\text { contaminated soil impacts groundwater, is } \\
\text { treated through Big Springs, or finds its way } \\
\text { to storm drains or the creek. }\end{array}$ \\
\hline
\end{tabular}


Table 2. continued

\begin{tabular}{|c|c|c|c|}
\hline Transport paths & Flux (g/d) & Data sources & $\begin{array}{c}\text { Explanatory comments } \\
\end{array}$ \\
\hline $\begin{array}{l}\text { 9201-2 to storm drain } \\
\text { system }\end{array}$ & $<0.1$ & $\begin{array}{l}\text { Henke, Bogle, and } \\
\text { Turner } 1996\end{array}$ & $\begin{array}{l}\text { No strong evidence, but potential for metallic } \\
\text { Hg in Outfalls 55, 47, and } 48 \text { because of } \\
\text { proximity to } 9201-2 \text {. }\end{array}$ \\
\hline 9201-2 to surface erosion & $<0.1$ & $\begin{array}{l}\text { Henke, Bogle, and } \\
\text { Turner } 1996\end{array}$ & $\begin{array}{l}\text { Contamination is primarily under building and } \\
\text { surrounding paved areas; however, recent } \\
\text { sampling of surrounding soils found high } \\
\text { levels of elemental Hg. }\end{array}$ \\
\hline Surface erosion to creek & $<0.1$ & $\begin{array}{l}\text { Henke, Bogle, and } \\
\text { Turner } 1996\end{array}$ & Little exposed soil and few erosion channels. \\
\hline Outfall 34 & 0.21 & $\begin{array}{l}\text { Southworth et al. } \\
2007\end{array}$ & $\begin{array}{l}\text { Hg concentration }(250 \mathrm{ng} / \mathrm{L}) \text { high enough to } \\
\text { indicate source within storm drain. }\end{array}$ \\
\hline Outfall 21 & $<0.01$ & $\begin{array}{l}\text { Southworth et al. } \\
2007\end{array}$ & \\
\hline \multicolumn{4}{|c|}{ UPPER EAST FORK POPLAR CREEK } \\
\hline $\begin{array}{l}\text { Atmospheric deposition } \\
\text { from rainfall }\end{array}$ & $<0.1$ & MDN 2007 & $\begin{array}{l}\text { Less than } 50 \% \text { of atmospheric wet deposition } \\
\text { is likely to reach EFPC. }\end{array}$ \\
\hline $\begin{array}{l}\text { Erosion of Hg- } \\
\text { contaminated stream banks }\end{array}$ & $<1$ & DOE 2001 & $\begin{array}{l}\text { Significant source prior to remediation. } \\
\text { Straight channel with protected (concrete, rip- } \\
\text { rap) banks minimizes erosion relative to } \\
\text { previous condition; however, proximity of } \mathrm{Hg} \\
\text { in bank soils to water may mean this is a } \\
\text { continuing significant source relative to other } \\
\text { facility sources. }\end{array}$ \\
\hline Flow augmentation & 0.03 & $\begin{array}{l}\text { Southworth et al. } \\
2007\end{array}$ & Melton Hill Reservoir source water low in $\mathrm{Hg}$ \\
\hline $\begin{array}{l}\text { EFPC streambed sediment } \\
\text { above Outfall } 109\end{array}$ & $1-3$ & $\begin{array}{l}\text { BJC 1999, } \\
\text { Southworth et al. } \\
\text { 2009; Southworth } \\
\text { 2010; DOE } 2011\end{array}$ & $\begin{array}{l}\text { Metallic Hg underlying armored fine } \\
\text { sediments acts as a continuing source of high } \\
\text { dissolved } \mathrm{Hg}(>50 \mu \mathrm{g} / \mathrm{L}) \text { that enters surface } \\
\text { flow. Sorption to surface particulates may be } \\
\text { mobilized as wet-weather export. }\end{array}$ \\
\hline $\begin{array}{l}\text { EFPC streambed sediment, } \\
\text { Outfall } 109 \text { to Station } 17\end{array}$ & $1-20+$ & $\begin{array}{l}\text { Southworth et al. } \\
\text { 2007, DOE 2010a } \\
\text { DOE } 2011\end{array}$ & $\begin{array}{l}\text { Highly variable depending on flow conditions. } \\
\text { Streambed likely acts as a sink for Hg during } \\
\text { base flow, accumulating Hg-rich particulates, } \\
\text { and releases this Hg inventory during wet- } \\
\text { weather flows. Large inventory of Hg- } \\
\text { contaminated particulates in streambed } \\
\text { (estimate > } 50 \mathrm{~kg} \text { of Hg) can contribute to } \\
\text { wet-weather flux. Difficult to separate role of } \\
\text { sediment versus other ungauged sources } \\
\text { during storm events. }\end{array}$ \\
\hline $\begin{array}{l}\text { Export at Station } 17 \\
\text { integration point }\end{array}$ & $23.7(19.4)$ & $\begin{array}{l}\text { DOE 2011, } \\
\text { DOE 2010a }\end{array}$ & $\begin{array}{l}\text { Mean of weekly averages, January-Sep 2010, } \\
23.7 \mathrm{~g} / \mathrm{d} \text {. FY } 2010: 19.4 \mathrm{~g} / \mathrm{d} \text {. Highly variable } \\
\text { depending on flow conditions. From } 2000 \text { to } \\
2009 \text {, average annual flux ranged from } 7.2 \mathrm{~g} / \mathrm{d} \\
\text { in } 2008 \text { to } 40 \mathrm{~g} / \mathrm{d} \text { in } 2005 \text {. Mean values highly } \\
\text { influenced by storm events. FIU calculation of } \\
\text { OREIS data (2004-2008) was } 18.5 \mathrm{~g} / \mathrm{d} \text {. } \\
\text { Between } 2004 \text { and 2008, roughly two-thirds of } \\
\text { flux was during base flow and one-third was } \\
\text { from storm flow. }\end{array}$ \\
\hline
\end{tabular}




\title{
Table 2. continued
}

\author{
Fluxes are mean estimates of daily export in grams per day. Where possible, daily flux averages over longer time periods (e.g., \\ months, year) are used that include base flow and storm flow numbers. However, for many sampling locations short-term \\ mercury sampling was conducted with little information regarding base flow/storm flow differences in flux. Explanatory \\ comments are the authors' assessment of the relative role of the source on overall flux, based on site knowledge and the \\ available data. \\ BSWTS $=$ Big Springs Water Treatment System \\ CMTS $=$ Central Mercury Treatment System \\ EFPC $=$ East Fork Poplar Creek \\ FIU = Florida International University \\ $\mathrm{FY}=$ fiscal year \\ $\mathrm{Hg}=$ mercury \\ $\mathrm{N} / \mathrm{S}=$ north/south \\ OREIS = Oak Ridge Environmental Information System \\ RMPE $=$ Reduction of Mercury in Plant Effluent (Program) \\ WEMA $=$ West End Mercury Area \\ WRRP $=$ Water Resources Restoration Program
}

deprioritized appears justified and prudent. The conceptual model suggests that mercury-related actions in the east end of the facility will be needed, based on the overall mercury fluxes and discharges. However, the conceptual model also indicates that such actions should be implemented in a manner that is consistent with the limited potential for impacting the overall efflux of mercury from the Y-12 Complex.

\subsubsection{Mass Balance Estimates}

The conceptual model presented here is a step forward in understanding the mercury issue at the Y-12 Complex by focusing, in one simple diagram, on (1) the complex connections and interactions between mercury sources and transport pathways, (2) the mercury flux (rather than concentration), (3) the effort to define the relative roles of sources and transport pathways in a generalized mass balance, and (4) the inclusion of uncertain or unknown pathways that need further study. A conceptual model for mercury is only as good as the data and information that go into it. With the various mercury sampling challenges at Y-12 and UEFPC, including a high number and variety of subsurface flow paths, closing the mass balance for mercury has always been difficult (Geraghty \& Miller 1985; BJC 1998; BJC 1999; DOE 2008). The model flux estimates are based on the most recent or best available flux data (Table 2) but are also based on the authors' site knowledge. Therefore, the conceptual model represents a consensus of the conceptual model development team and provides a visual interpretation of current conditions. It should not be confused with output from a numerical modeling effort.

Over the years mercury flux at the Y-12 Complex has been measured at different times, under various flow conditions, and with different sampling methods. Most previous sampling has been done at dryweather base flow, with less understanding of storm flow flux. Calculations of flow under wet-weather conditions can be challenging, particularly in storm drains with poor access. For quantifying flux in the conceptual model, priority was given to flux averages obtained over longer time periods (months, one year) using flow-paced continuous sampling devices (DOE 2011). Therefore, flux averages in the conceptual model include base flow and storm flow sampling to the degree possible. The role of large storm events can be seen in the difference between median and mean flux. If an adequate number of samples are obtained and the goal is to evaluate mercury flux that is most often encountered by stream biota, the median flux value determined from the cumulative distribution function may provide a more stable central tendency indicator (DOE 2011). However, mean or total flux may better account for the influence of major storm events on flux. Regardless of the averaging method, the flux ranges in the conceptual model diagram bound both the median and mean results where available. Because mercury flux can vary considerably depending on flow, interpretation of instantaneous results (e.g., grab samples) 
under various flow regimes over space and time can be difficult. For many of the storm drain sites grab sample data were the only information available.

The variability in estimated mercury flux over time, location, and flow conditions is well demonstrated by the results presented in Tables 3 and 4. In the early 1980s flux within WEMA storm drain conduits (Outfalls 150, 160, 163, and 169) was in the range of tens of grams per day (UCC 1983a), but since 1993, and after various remedial and water-use changes within the facility, average flux has been in the singledigit grams per day or lower at the WEMA conduits. The role of the WEMA outfalls relative to the flux at Outfall 200 (which receives all the flow from these outfalls; measured at 200A6) has varied over the 1996 to 2010 time period, ranging from 171 to $45 \%$ (sum of WEMA outfalls divided by 200A6 flux). Based on data showing higher fluxes at Outfall 200 than could be accounted for by the four conduits, ungauged flux within the north/south (N/S) pipe was calculated as a source term in the feasibility studies leading to the Phase 1 ROD (DOE 2000). An evaluation of the mass balance of the four major conduits (Outfalls 150, 160,163 , and 169) relative to the Outfall 200 integration point indicated a good-to-excellent correlation and mass balance in the Reduction of Mercury in Plant Effluent (RMPE) Program 1996-1997, 19992000, and 2010 sampling (including select dry-weather, wet-weather, and overall flux averages). An analysis of mass balance that includes all FY2010 data reveals a much higher flux at Outfall 200 (25.6 g/d) than can be accounted for by the four conduits ( $8.9 \mathrm{~g} / \mathrm{d}$ ) (Table 4; DOE 2011). However, two high mercury spikes during high flow events account for this discrepancy and under base flow conditions a major source within the North/South pipe (from sediment or groundwater infiltration) appears unlikely. Without more direct sampling and characterization within the pipe, the current estimate is that the four outfalls account for most, if not all, of the flux at Outfall 200.

Outfall 200 flux can be a large percentage of the total flux at Station 17. Over the last three fiscal years (2008-2010) the mean annual flux at Outfall 200, and the median fluxes in FY 2008 and FY 2009, were greater than at Station 17 (Table 4). When sampled under dry-weather base flow conditions, as was done for the 2007 synoptic study and a week in April 2010, Outfall 200 was $78-100 \%$ of the measured flux at Station 17 (Table 3). The weight of evidence suggests that Outfall 200 can

\section{Key Point:}

Outfall 200 is the most significant current input of mercury from the facility to East Fork Poplar Creek. explain at least $70-80 \%$ of the flux at Station 17 under low flow, and the pattern appears to hold up during most years with relatively normal rainfall.

However, fluxes at Outfall 200 and Station 17 are known to vary considerably, especially during high flow time periods. The percentage of Outfall 200 relative to Station 17 flux can be as low as 20-40\% (Table 3). During a wet-weather week in July 2010 and as the weekly average from January through September 2010 (a relatively wet period), Outfall 200 represented approximately a third of the flux at Station 17-results similar to those reported in the ROD feasibility studies using 1999-2000 data and data from FY 2003. Sediments in UEFPC may act as a sink for mercury under dry-weather conditions, with sediments and suspended solids moving downstream and contributing to high flux numbers during extremely high flow conditions (Southworth et al. 2009, Southworth et al. 2010). Contaminated sediments in Lake Reality are another potential source to Station 17 of suspended solids and mercury during high flow conditions. Mercury flux monitoring at Station 17 is affected both by large changes in water flow volumes and by impacts to mercury concentration from short-term spikes of particle-associated mercury (DOE 2011). Ungauged flux downstream of Outfall 109 to Station 17 represents a very uncertain and poorly-understood contribution to the UEFPC mass balance during wet-weather periods (Fig. 4). Further complicating the downstream mass balance is the fact that year-to-year variation in export estimates at Station 17 is very large and dependent on the sources and handling of data used to generate the estimate (e.g., grab samples vs. composites, inclusion or exclusion of very high spikes, and averaging methods). 
Table 3. Select flux estimates (grams per day) and mass balance at WEMA drain conduits, Outfall 200, and Station 17, 1980 s-2010

\begin{tabular}{|c|c|c|c|c|c|c|c|c|c|}
\hline Outfalls & Early $1980 s^{1}$ & $\begin{array}{c}\text { 1996-1997 } \\
\text { RMPE }^{2}\end{array}$ & $\begin{array}{c}\text { 1999-2000 } \\
\text { (ROD baseline) }\end{array}$ & $\begin{array}{c}\text { 2002-2003 } \\
\text { RER }^{3}\end{array}$ & $\begin{array}{c}2007 \\
\text { Synoptic Flux } \\
\text { Study }^{4}\end{array}$ & $\begin{array}{c}2009 \\
\text { WEMA-SD } \\
\text { Remediation }^{\text {Baseline }}{ }^{5}\end{array}$ & $\begin{array}{c}2010^{6} \text { Dry } \\
\text { Weather April } \\
21 \text { week }\end{array}$ & $\begin{array}{c}\quad 2010 \\
\text { Wet Weather } \\
\text { Jul } 14 \text { week }\end{array}$ & $\begin{array}{c}2010 \\
\text { Jan-Sep }\end{array}$ \\
\hline \multicolumn{10}{|c|}{ Flux } \\
\hline OF150 & 15 & 0.3 & 0.14 & 1.0 & 0.6 & 1.0 & 1.0 & 4.0 & 1.4 \\
\hline OF160 & 20 & 0.5 & 0.52 & 0.6 & 0.4 & 0.6 & 0.2 & 2.1 & 0.6 \\
\hline OF163 & 27 & 1.3 & 0.28 & 6.1 & 8.0 & 1.4 & 2.1 & 22.8 & 5.5 \\
\hline OF169 & 60 & 3.2 & 0.87 & 4.6 & NS & 1.3 & 1.2 & 3.4 & 1.4 \\
\hline OF Sum & 95 & 5.3 & 1.81 & 12.3 & NS & 4.2 & 4.5 & 32.3 & 8.9 \\
\hline 200A6 & NS & 6.9 & 2.31 & 7.2 & 5.2 & 9.5 & 4.6 & 31.2 & 8.6 \\
\hline Station 17 & 42 & 11 & 11 & 23 & 5.1 & 11 & 6 & 141 & 24 \\
\hline \multicolumn{10}{|c|}{ Mass Balance } \\
\hline OF Sum/200A6 & NS & $77 \%$ & $78 \%$ & $171 \%$ & NS & $45 \%$ & $98 \%$ & $104 \%$ & $103 \%$ \\
\hline 200A6/Station 17 & NS & $61 \%$ & $21 \%$ & $32 \%$ & $100 \%$ & $89 \%$ & $78 \%$ & $22 \%$ & $36 \%$ \\
\hline
\end{tabular}

${ }^{1}$ Flux estimates from early 1980s reported in Energy Systems, 1997; UCC 1983b

${ }^{2}$ Data from the Reduction of Mercury in Plant Effluent Program (Energy Systems, 1997). Represents monthly dry weather sampling results.

${ }^{3} 2003$ fiscal year data reported in the Remediation Effectiveness Report. Mean annual flux in g/day.

${ }^{4}$ ORNL-collected unpublished data. Same time sampling dry weather base flow conditions. Flow could not be obtained within WEMA storm drains on sampling date;

flux estimated by using 2007-measured concentration and past dry weather flow numbers (BJC 1998).

${ }^{5}$ Data collected by Y-12 Complex staff as part of storm drain investigation, except for 200A6 and Station 17, which is from DOE 2010 (RER)

${ }^{6}$ All 2010 data is from the Water Resources Restoration Program, collected for DOE 2011

NS = not sampled or applicable 
Table 4. Contrasting flux (grams/day) at Station 17 and Outfall 200, showing the importance of wet-weather events on calculated annual means

\begin{tabular}{|c|c|c|c|c|c|c|c|c|c|c|c|c|c|}
\hline \multirow[b]{2}{*}{ Year } & \multicolumn{6}{|c|}{ Station 17} & \multicolumn{6}{|c|}{ Outfall 200} & \multirow[b]{2}{*}{$\begin{array}{l}\text { Annual } \\
\text { rainfall }^{d}\end{array}$} \\
\hline & $\mathbf{N}^{a}$ & $\operatorname{Min}^{b}$ & Median $^{b}$ & Mean $^{b}$ & $\operatorname{Max}^{b}$ & $\begin{array}{c}\text { Annual } \\
\text { flux }^{c}\end{array}$ & $\mathbf{N}^{a}$ & $\operatorname{Min}^{b}$ & Median $^{b}$ & Mean $^{b}$ & $\operatorname{Max}^{b}$ & $\begin{array}{c}\text { Annual } \\
\text { flux }^{c}\end{array}$ & \\
\hline FY 2000 & 365 & 5.7 & 13.8 & 33.0 & 984 & 12,045 & & & & & & & 52.0 \\
\hline FY 2001 & 365 & 4.5 & 10.9 & 25.7 & 648 & 9,392 & & & & & & & 45.9 \\
\hline FY 2002 & 365 & 4.2 & 11.3 & 20.0 & 341 & 7,309 & & & & & & & 52.7 \\
\hline FY 2003 & 365 & 3.2 & 11.1 & 24.0 & 404 & 8,746 & & & & & & & 73.7 \\
\hline FY 2004 & 366 & 5.4 & 10.4 & 22.5 & 988 & 8,231 & & & & & & & 56.4 \\
\hline FY 2005 & 365 & 5.5 & 10.4 & 39.9 & 2,434 & 14,569 & & & & & & & 58.9 \\
\hline FY 2006 & 365 & 3.5 & 7.1 & 10.9 & 88 & 3,967 & & & & & & & 46.4 \\
\hline FY 2007 & 365 & 1.9 & 7.0 & 10.8 & 69 & 3,935 & 365 & 1.2 & 4.7 & 5.5 & 31 & 2,001 & 36.3 \\
\hline FY 2008 & 366 & 1.8 & 5.4 & 7.0 & 67 & 2,556 & 353 & 2.6 & 6.2 & 10.5 & 190 & 3,691 & 46.0 \\
\hline FY 2009 & 365 & 1.8 & 7.0 & 10.7 & 124 & 3,901 & 359 & 3.1 & 7.4 & 16.8 & 671 & 6,040 & 62.5 \\
\hline FY 2010 & 365 & 0.4 & 8.0 & 19.4 & 532 & 7,081 & 365 & 2.6 & 6.9 & 25.6 & 687 & $9,342^{\mathrm{e}}$ & 58.8 \\
\hline
\end{tabular}

${ }^{a}$ number of days with calculated mercury flux

${ }^{b}$ grams per day mercury flux

${ }_{d}^{c}$ grams per year discharged

${ }^{d}$ total annual rainfall (inches) measured in Oak Ridge

${ }^{e}$ two discharge events produced high concentration spikes reflected in the annual summary

$\mathrm{FY}=$ fiscal year

Note: Big Springs Mercury Treatment System came on line at the beginning of FY 2006. 



\section{DESCRIPTIONS OF MERCURY SOURCE AND TRANSPORT PATHWAYS}

More detailed descriptions of the principal mercury source areas, contaminant migration pathways, and discharge points for WEMA and the east end of the Y-12 Complex (the East Plant Area) are provided below. Evaluation of the relative contributions of source areas to the overall flux considers historical and present studies as well as the authors' site knowledge. The relative roles of source areas have changed over time as various facility modernizations, D\&D, and remedial efforts have been implemented. Changes are expected in the future, particularly in the near term in WEMA, where storm drain remediation activities are planned.

\subsection{WEST END MERCURY AREA}

In general, WEMA is defined as the area of the Y-12 Complex west of Outfall 200 (Fig. 1) and east of the Old Savage Yard. It comprises many large buildings that handled mercury, with surrounding contaminated soils most often under concrete or asphalt at the surface. A storm drain system connecting pipes of different ages transports water from near buildings to Outfall 200 at the headwaters of EFPC.

\subsubsection{WEMA Buildings}

Facilities in WEMA that handled mercury include Bldgs. 9204-4 (Beta 4), 9201-5 (Alpha 5), and 9201-4 (Alpha 4). These facilities now contain contaminated process equipment, legacy material, and portions of facility structures that are contaminated. A large percentage of the known 193,000 kg of mercury lost to soil at the Y-12 Complex was the result of historical spills (1950s-1960s) in the WEMA (ChemRisk 1999). Significant but unknown quantities of metallic mercury were spilled to floor drains and basements in the buildings and on soils, engineered backfill, and bedrock surrounding the buildings (Fig. 1). The lower portions of building foundations, basements, and surrounding fill, soil, and bedrock that are below the regional groundwater table are also contaminated with mercury.

The piping systems inside the buildings contain residual mercury that was spilled into the floor drains or discharged from building sumps. Metallic mercury in the pipes is dissolved and transported into process and storm water that is routed through the pipes to the storm drain system. There is evidence to suggest continued migration of metallic mercury from the piping associated with the buildings to the storm drain system, but there is a high level of uncertainty as to its relative role.

\section{Key Point:}

There are many data gaps

and uncertainties related to the various transport

pathways. To resolve these issues, improved data

(e.g., better flow gauging),

additional data (e.g., drain

system), and/or careful

monitoring (e.g., D\&D

activities impacting shallow

groundwater flow near

buildings) are needed.

Groundwater adjacent to and under the buildings is collected into sump-pump systems. Sump pumps within the basements of 9201-4 and 9201-5 discharged directly to the storm drain network until 1996 when the Central Mercury Treatment System (CMTS) was completed. The sumps added 5-10 g of mercury per day to Outfall 163, but output was reduced to $2.5 \mathrm{~g} / \mathrm{d}$ by the removal of inputs of chlorinated process water and steam condensate to the system (BJC 1999). Sump operation induces groundwater flow through metallic-mercury-contaminated soil around building foundations. These actions may generate highly contaminated water (approximately $67 \mu \mathrm{g} / \mathrm{L}$ ) similar to that expected, based on the solubility of elemental mercury $(60 \mu \mathrm{g} / \mathrm{L})$, to occur within sediments and footers underlying the storm drain system. A methanol spill in a sump in 9201-5 in December 2005 rendered the output from sumps in that building untreatable at CMTS, and subsequently all pumps in 9201-5 were shut down and the basement was allowed to fill with water. 
Remedial activities to address flux from residual contamination within the buildings as part of RMPE and other programs have included plugging floor drains, rerouting some piping, cleaning out sumps, and generally reducing the amount of water moving through the building and into storm drains (Rothschild et al. 1984; Turner et al. 1985). These activities have significantly reduced the flux of mercury discharging to the storm drain system, although much of the mercury still remains in place.

The current Integrated Facility Disposition Project scope incorporates both D\&D and remediation of some of the mercury-contaminated facilities in WEMA at the Y-12 Complex, specifically:

- D\&D: Alpha 4, 5, and Beta 4 and

- remedial action (RA): remaining slabs and soils (related to Alpha 4, 5, and Beta 4).

The large uncertainty connected with the nature, quantity, and location of mercury associated with these buildings will most certainly affect how future Y-12 D\&D and RA activities will proceed.

\subsubsection{WEMA Storm Drain System}

Extensive investigation into sources of mercury to EFPC was conducted in the early 1980s to provide information vital to guiding efforts to reduce mercury inputs to EFPC under the RMPE Program (Rothschild et al. 1984; Turner et al. 1985). One conclusion of these studies was that "mercury discharges arise largely because residual deposits of metallic mercury located in the drainage system are being slowly solubilized or resuspended by uncontaminated groundwater and process water which flows through the system" (Turner et al. 1985). Another important conclusion was that "mercury [in groundwater] does not appear to be moving in significant quantities in an aqueous phase" (Rothschild et al. 1984). Measurements of base-flow mercury export indicated that the largest sources were the storm drain system draining Bldgs. 9204-4 (55 g/d), 9201-5 (40 g/d), 9201-4 (25 g/d), and the Bldg. 81-10 site (30 g/d). Cleaning and relining extensive sections of the storm drain systems draining the 9201-4, 9201-5 and 9204-4 sites and rerouting clean water that previously entered those storm drain segments eliminated more than $90 \%$ of the mercury export previously associated with those sites, resulting in a cumulative mean daily flux of $7.5 \mathrm{~g} / \mathrm{d}$ through Outfalls 169, 163, 160, and 150 over the 1993-2003 period (DOE 2004). The uppermost sections of the drainage system near the mercury-use buildings were not remediated and continue to contain metallic-mercury deposits within gravel sediments and almost certainly in footers and backfill adjacent to corroded and damaged pipes. High mercury concentrations in the vapor phase have been measured in nonremediated sections of the system, and the waterborne mercury concentration in one such section exceeded $60 \mu \mathrm{g} / \mathrm{L}$ in measurements made in 2007.

Based in part on recent WEMA storm drain investigations (Lind 2009; Fig. 5), it is highly probable that the nonremediated segments of the drainage system surrounding the mercury-use area remain a primary source of mercury entering the surface flow of EFPC above Outfall 200. The 2009 WEMA storm drain project conducted extensive video surveys and mercury analyses within WEMA. As in other surveys, the results pointed to the importance of the 9201-4 area and near-building storm drain sources to Outfall 163 and Outfall 150, where mercury flux exceeded $1 \mathrm{~g} / \mathrm{d}$ at multiple locations. Mercury flux in drain lines contributing to Outfalls 160 and 169 were generally lower during these surveys, ranging from 0.2 to 1.0 g/d.

The north storm drain line into the E-3320 catch basin (i.e., E-3250 in RMPE reports, see Fig. 5) was a major source of mercury (2-3 g/d) to Outfall 169 in the 1990s. A collection line inserted into the north drain line of E-3320 in 1998 captured much of the dry-weather flow from this line and routed it to CMTS 


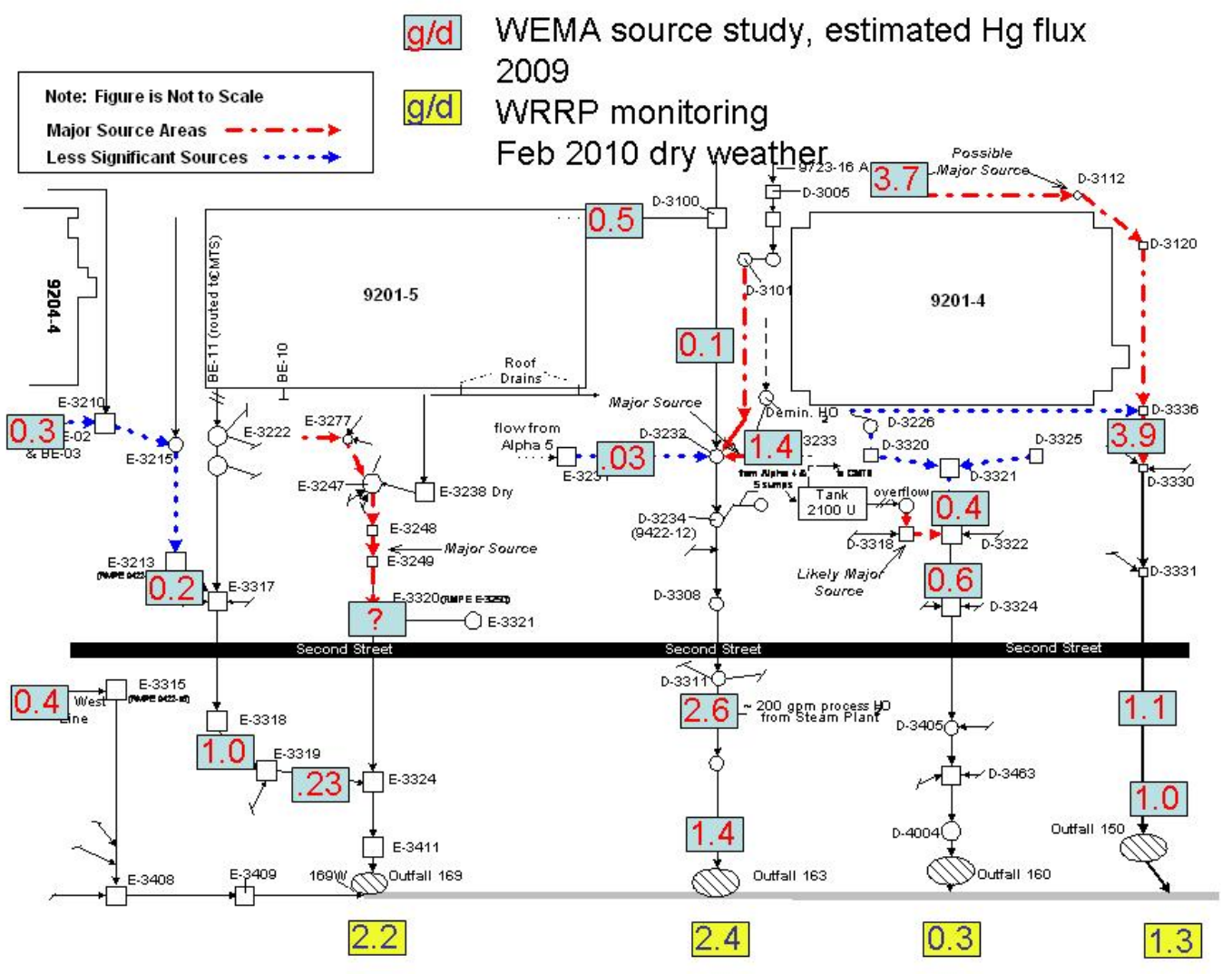

Fig. 5. Estimated mercury fluxes (grams per day) within the WEMA storm drain system based on 2009 WEMA storm drain remediation project sampling (courtesy of D. Lind, Y-12 Complex) and Water Resources Restoration Program sampling in February 2010.

(BJC 1999; BJC 2000). After the discontinuation of the routing of this water to CMTS, the flow pattern just upstream of this catch basin changed. Although WEMA storm drain remediation sampling did not identify mercury flux at the Outfall 169 location near the E3320 catch basin (Fig. 5), recent sampling by ORNL staff (Sept. 30, 2010) of storm drain water at E-3249 (just north of E-3320) revealed total mercury of $25 \mu \mathrm{g} / \mathrm{L}$ and sufficient flow to collect a large volume of water. Although Outfall 163 appears to be a more important contributor to Outfall 200 mercury flux in recent years, in part due to relatively high flows, Outfall 169 probably remains an important contributor of mercury to overall WEMA flux.

In the late 1980s the main storm drain conveyance for EFPC into which the WEMA outfalls discharge was plugged and replaced with a new pipe located several meters to the north. The south pipe was removed as a source of mercury to UEFPC, resulting in elimination of approximately $30 \mathrm{~g}$ of mercury per day to the EFPC headwaters. By the early 1990s, metallic-mercury sources within the WEMA storm drain system were considered the major source of dissolved mercury to west end surface waters.

Metallic mercury submerged in water is subject to direct dissolution of elemental mercury $(\operatorname{Hg}(0))$ and oxidative dissolution of inorganic mercury (Hg(II)) at the metal-water interface (Amyot et al. 2005). Mercury concentrations in excess of $50 \mu \mathrm{g} / \mathrm{L}$ have been measured in interstitial water at a localized site in UEFPC, where metallic-mercury deposits underlie armored soft sediments. It is believed that this site is a significant source of mercury to the surface flow of EFPC (BJC 1998). It is nearly certain that a similar 
phenomenon occurs within the storm drain network upstream; residual mercury in the footer, backfill, and gravel deposits within the pipe is a likely source to water. Positive hydrostatic pressure from groundwater could force highly contaminated water surrounding pipes into the drainage system via joints and cracks in nonremediated sections, while flow within the footer/backfill could enter the creek at points downstream.

\subsubsection{WEMA Soils and Groundwater}

A 1980s investigation of subsurface mercury at Y-12 found high concentrations of mercury in shallow (<10 ft) soil near Bldgs. 9201-2, 9201-4, 9201-5, 9204-4, and 81-10, but little evidence of deeper movement at most sites (Rothschild et al. 1984). There is uncertainty as to whether metallic mercury in soil near WEMA buildings is a significant source to the storm drain system. There is no doubt that metallic mercury continues to enter the storm drain network from sources in WEMA; however, intrabuilding sources including blocked floor drains may be the most likely sources to downstream storm drain lines. Broken or severely damaged conduits are necessary for soil mercury to enter sewers. Mercury entering damaged storm drains is most likely from surrounding footers or fill material and not from the surrounding native soils. Although there was some evidence of cracked and broken pipe, the 2009 WEMA storm drain project did not observe large sections of sewer with catastrophic damage. That said, very small pipes near buildings were not surveyed as effectively as larger sewer lines.

Groundwater connectivity between soil contamination, storm drains, shallow (soil-zone) groundwater, construction-filled stream channels, and karst and nonkarst bedrock flow paths is important but not well understood (Fig. 4). Based on limited available information, groundwater within WEMA does not show strong evidence of mercury mobilization from soil, with groundwater concentrations in wells at most contaminated sites being lower than concentrations in storm drains and stream surface flow. Previous studies have been able to detect and delineate groundwater plumes of nitrate, sulfate, chloride, conductance, and alkalinity, but there has been little evidence of a significant plume of mercurycontaminated groundwater, although mercury has been detected in groundwater wells (Rothschild et al. 1984; DOE 1998). Most samples from the 1984 study were analyzed for total mercury without filtration and thus often contained mercury-enriched particulates. Although the conclusions of the study remain valid, high-sensitivity analyses of filtered samples from the same well may be capable of delineating mercury-contaminated groundwater.

The potential exists for groundwater mercury at the Y-12 Complex to be reduced or methylated by interaction with other soil or groundwater contaminants or by actions taken to remediate these cocontaminants. For example, a methylating environment may be present in localized soil and groundwater zones that contain hydrocarbon contamination and a suitable microbial community. Similarly, the potential for generating a methylating environment should be considered when evaluating the efficacy of bioremediation options, such as electron donor addition, that alter redox conditions to stimulate the reductive dechlorination of chlorinated volatile organic compounds. Groundwater also presents challenges associated with the dissolution and surface oxidation of elemental mercury droplets (similar to the above discussion related to storm drains). Limited site-specific data and supporting scientific literature are available on these topics. Nonetheless, the potential significance of these topics should be recognized and incorporated in a general fashion when developing environmental management plans and mercury reduction activities for the Y-12 Complex.

\subsubsection{The 81-10 Site as a Source}

Mercury contamination at the 81-10 site, situated above the Maynardville Limestone bedrock, extends deeper than at sites situated above shale bedrock (Rothschild et al. 1984). This site was the location of a mercury distillation/recycling system (i.e., a retort) and stored drums of mercury sludge. Metallic mercury that was spilled on the concrete pad at 81-10 leaked into a sump that overflowed to the main storm drain 
(N/S pipe) conveying to EFPC (Turner et al. 1985). The 81-10 site is underlain by limestone that has karst development. It is believed that metallic mercury spilled on-site may have penetrated into the karst system (Moline et al. 1998; Moline et al. 2001; DOE 2001). It is also possible that the original creek channel adjacent to the 81-10 site (now covered by the N/S pipe) was a losing reach that discharged water into the karst system. This is similar to what is currently observed in Bear Creek, which is in the same geologic formation as UEFPC. Metallic mercury in the footer underlying the original N/S pipe could thus act as a source to the karst system. Dissolved $\mathrm{Hg}(0)$ and $\mathrm{Hg}(\mathrm{II})$ were detected in a piezometer (shallow well installed mainly for water-level measurements) that may have encountered a solution cavity more than $100 \mathrm{~m}$ downstream of Outfall 200. This study appeared to indicate there was a connection to the Big Springs (karstic groundwater) discharge (Outfall 51) adjacent to 9201-2 located $800 \mathrm{~m}$ downstream (Moline et al. 1998; Moline et al. 2001; DOE 2001). Another tracer study conducted in well GW-696 located at 81-10 was not conclusive. However, GW-696 may be screened above the regional water table and not connected with the karst system. Overall, the data obtained to date suggest that some of the groundwater mercury entering the BSWTS may originate from the 81-10 site (or nearby deposits). However, contributions from shallow groundwater around Bldg. 9201-2 (Alpha 2) cannot be ruled out.

Soil and sediment cores were collected in 2010 at the 81-10 site in an attempt to address characterization data gaps that had been identified after previous studies and as a substitute for treatability studies called for in the ROD (DOE 2002; ORISE 2010). Mercury contamination was found in cores taken adjacent to the remnant concrete slab of the former facility and, when present, tended to be localized to the upper 10 feet of soil. Soils surrounding the former 9822 Sediment Basin produced relatively low mercury concentrations $(<1 \mathrm{mg} / \mathrm{kg})$, leading the authors to conclude that the basin is probably not a source of contamination to the creek. Along the northern edge of the slab of the former retort furnace, however, high concentrations ( $>300 \mathrm{mg} / \mathrm{kg}$ ) were observed at moderate depths, from 14 to $30 \mathrm{ft}$, which are significantly above the level of the basement rock. Visible mercury beads and droplets were observed in two of the cores collected during this study (Fig. 6), and $1400 \mathrm{mg} / \mathrm{kg}$ was measured in a third. Mercury contaminated soil above $325 \mathrm{mg} / \mathrm{kg}$ was estimated to cover a surface area of approximately $8080 \mathrm{ft} 2$.

As part of EM-32-funded projects, ORNL and SRNL staff conducted additional investigations of the 8110 site in 2010. ORNL staff conducted a detailed interrogation of two cores that indicated that metallic mercury seems to be associated with coarser, more gravelly zones, especially those on top of lowpermeability clayey zones (perhaps a historical surface grade) where the mercury tends to pool on top of the clay. These coarser zones probably provide avenues for transport and downward migration of the mercury beads. SRNL staff used a membrane interface probe (MIP) (Rossabi et al. 2003) as a potential tool for rapid and inexpensive delineation of elemental mercury sources in soil and shallow groundwater. Proof-of-concept testing of the MIP for elemental mercury detection was completed at site 81-10 in August 2010. Measurements were made directly adjacent to locations at which ORISE baseline samples were collected (both clean and contaminated locations). Initial MIP results confirmed the higher levels of mercury near the old retort furnace.

Overall, there is clear evidence of significant mercury concentrations in soils near the 81-10 retort furnace, but many questions remain to what degree, if at all, 81-10 is a source of mercury to EFPC. If the conclusions of the 1980s studies are still valid and mercury from 81-10 is able to move though subsurface conduits to the Big Springs area, then 81-10 mercury is likely being treated by BSWTS and is not a major current source of mercury to the creek. If there is a direct connection between 81-10 and the creek it is probably a small contribution relative to other sources, based on the relatively small change in flux between Outfall 200 and Station 17 during base flow conditions. 


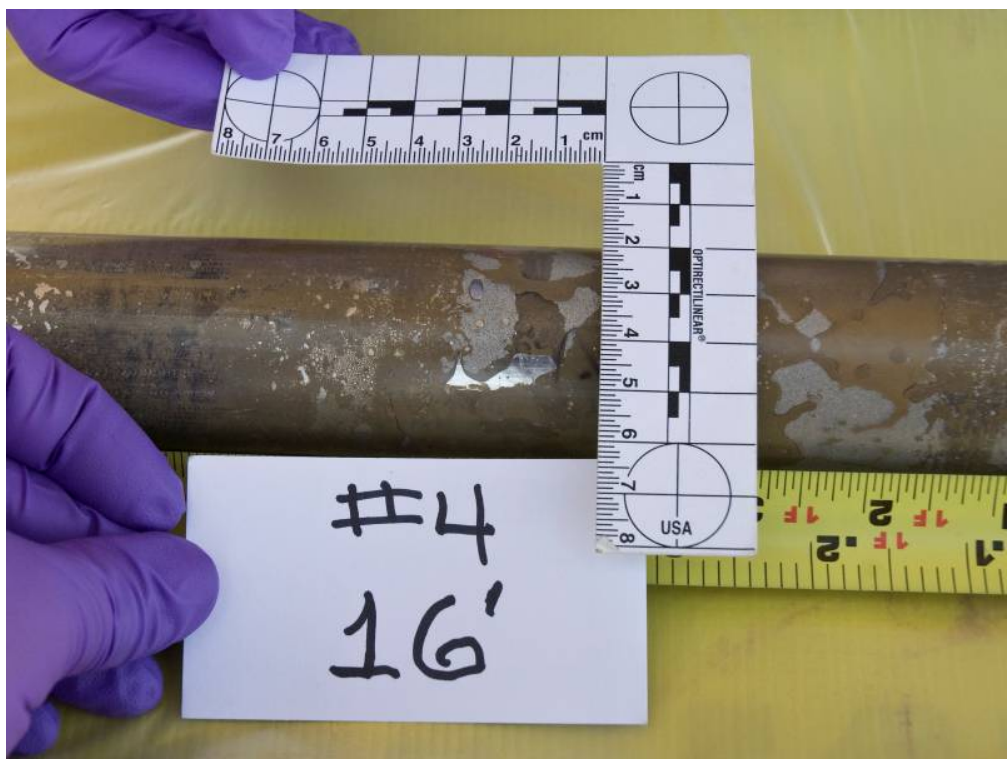

Fig. 6. A soil core in a Lexan liner from the 81-10 site showing visible mercury blobs and droplets.

\subsubsection{WEMA Surface Soil Erosion and Wet-Weather Export}

Studies of storm flow mercury transport in EFPC conducted in 1997 and 1998 clearly demonstrated that most of the increased mercury flux associated with rainfall events originated from erosion/resuspension of fine particulates from the open streambed downstream from Outfall 200 rather than within the enclosed storm drain network above the outfall (Energy Systems 1997, BJC 1998; BJC 1999; BJC 2000). Mercury concentrations on particulates at Outfall 200 during elevated flow were typically low ( $<20 \mathrm{mg} / \mathrm{kg})$, while concentrations at downstream sites were 50-100 mg/kg. Similarly, storm-flow-related mercury flux at a site $5000 \mathrm{ft}$ downstream was fivefold higher than at Outfall 200. Although mercury flux at Outfall 200 increased in response to increased discharge during wet weather, most of the increase was associated with greater flux of dissolved mercury rather than inputs of particle-associated mercury expected from erosion of contaminated surface soil. There was no indication that soil erosion from the Old Salvage Yard and other areas in the west end of the Y-12 Complex was an important source of mercury to the N/S Pipe or EFPC.

Various conduits leading from buildings to the storm drain network, such as floor and roof drains, have the potential to contain residual deposits of metallic mercury. Increased flow in such pathways during rainfall events can move metallic mercury downstream into the storm drain network or move metallic mercury already in the storm drain system farther downstream. Periodic appearance of metallic mercury in junction boxes within the storm drain network (and subsequent removal by Y-12 staff) gives evidence that such movement is occurring, but the source and extent of the movement are unknown and need further investigation.

The conceptual model provided here is not intended to be a mechanistic description of mercury transport and processing within the stream, where there are additional complications related to the form of mercury (dissolved, particle-borne, colloidal elemental mercury, or methylmercury). However, evaluation of existing monitoring data suggests that approximately two-thirds of the mercury export occurs under base flow conditions and the remainder under wet-weather flows. There is a need to quantify mercury export from upstream of Outfall 200 through the course of storm events and compare that flux simultaneously with export at other Y-12 storm drains and downstream in EFPC (Station 8, Station 17, and EFPC sites within the city of Oak Ridge). A study conducted under RMPE was restricted to UEFPC and found that 
mercury export increased at all sites, as expected, but far greater inputs arose from the open stream downstream of Outfall 200 than from the enclosed storm drain system upstream. As described earlier, there are additional complications with determining storm flow flux in downstream waters that obfuscates obtaining an accurate mass balance.

\subsection{EAST PLANT AREA}

The principal mercury source areas, contaminant migration pathways, and discharge points for the east end of the Y-12 Complex (the East Plant Area), defined here as the zone between Outfall 200 (at the boundary of WEMA) and Station 17 near Scarboro Road, are shown in Figs. 1 and 2. Within the Y-12 Complex facility boundary, UEFPC is located within the eastern part of the plant and receives a number of relatively low-concentration mercury inputs from storm drains, process water lines, groundwater (including karst-related inputs via Outfall 51), sheet flow/erosion, and a treatment system discharge.

Key Point:

Some mercury-contaminated soils/materials areas have relatively low concentrations or are not near active water transport pathways. These do not appear to be major sources of mercury to the stream.

The East Plant Area appears to contribute a small percentage of the total flux to the creek compared to inputs from WEMA via Outfall 200 into the creek's headwaters and contributions from the contaminated creek sediment (Fig. 4). This low-level flux from the East Plant Area (outside of bank soils) assumes continued treatment of groundwater contamination in the area. A complicating factor is that east end sampling for mercury in storm drains, apart from Outfall 51 and BSWTS-related sampling, has been less comprehensive than the sampling at WEMA. Most often the available mercury data used in the conceptual model were from intermittent grabs during base flow conditions.

\subsubsection{East Plant Area Buildings}

The East Plant Area contains a number of buildings in which mercury was historically handled. Those buildings include 9201-2 (Alpha 2), 9733-1, 9202, and 9733-2. Mercury has been detected within and surrounding other buildings and soils in the east end but at much less significant levels. Alpha 2 represents the most difficult remediation challenge in the east end relative to mercury, with major losses reported to surrounding soils, as well as major spills inside the building that seeped to the building's basement. Most of the building drain, sump, and groundwater issues identified for the WEMA buildings are applicable to Alpha 2. A sump in the basement of Alpha 2 extracts mercury-contaminated water that is pumped to BSWTS, providing about a gram per day of mercury. The mercury in basement water is presumed to come from groundwater surrounding the building, legacy mercury from spills in the building itself, and abandoned piping still in the facility. Soils surrounding the 9733 area were partially remediated many years ago, but elemental mercury remains elevated, as evidenced by recent ORNL soil-gas sampling in the area. At all of the mercury-use buildings without dewatering sumps, residual mercury contamination exists within soil and shallow groundwater beneath and adjacent to the buildings, but the extent to which this mercury finds its way to storm drain or surface flow paths to the creek in this area is not well understood.

\subsubsection{East Plant Area Soils and Groundwater}

The east end of the facility is influenced by a primary source of groundwater flow that travels from west (within WEMA) to east (Fig. 1). Soils and groundwater around the 81-10 site within WEMA contain high mercury concentrations. Mercury in groundwater may flow from the 81-10 area into the east end of the facility through preferential flow paths including (1) karst conduits and fractures at both intermediate and deep intervals in the Maynardville Limestone, (2) the old UEFPC stream channel, and (potentially) (3) 
shallow groundwater flow along pipes and porous fill areas. The hydrogeologic system in the eastern area of Y-12 is complex, as the various construction activities in the eastern plant area have affected groundwater and surface water flow patterns. Mercury-contaminated groundwater in this area is thought to be primarily captured by BSWTS.

The amount of mercury removed by the treatment system has far exceeded that which previously entered EFPC via Outfall 51, especially during the first few years of operation. Based on monthly grab and weekly flow estimates, high influent flux to the treatment system was observed during the first three years of BSWTS operation (maximum monthly grab of $97.7 \mathrm{~g} / \mathrm{d}$; maximum annual average in 2007 was $22 \mathrm{~g} / \mathrm{d}$ ). The average influent flux to BSWTS over the last 3 years (2008-2010) was $6 \mathrm{~g} / \mathrm{d}$, about 2 to 3 fold higher than historical average flux from Big Springs to EFPC.

\section{Key Point:}

The Big Springs Water Treatment System removes significant quantities of mercury from the karst system in the East Plant Area at a rate two to three times higher than pretreatment flux to the creek.

The high influent flux to BSWTS suggests that BSWTS treated particulate mercury that previously did not reach EFPC, or the collection system altered subsurface flow pathways around 9201-2 that mobilized mercury.

In 2010 ORNL conducted shallow (1 ft) soil-gas sampling investigations around 9201-2 in an area in which elemental mercury was detected when subsurface piping was laid as part of new construction activities. The soil-gas sampling results suggest the mercury contamination is limited to an area to the east and south of 9201-2, but deeper sampling is needed to confirm these observations.

Outfall 51 is the most contaminated outfall exiting the East Plant Area into the creek and represents the bulk of known mercury-contaminated groundwater still entering the creek. Outfall 51 also receives BSWTS bypass flow that can be substantial during high precipitation events. The average flux in FY 2010 at Outfall 51 was $0.9 \mathrm{~g} / \mathrm{d}, 2-3$ times higher than the average in recent years, most certainly due to BSWTS bypass during high flow events. Outfall 51 water historically contained a strong dissolved elemental mercury signal, potentially linked to subsurface metallic mercury in the limestone solution cavity network upstream (81-10 or under N/S pipe).

Shallow groundwater in the East Plant Area is likely to be intercepted by storm drains, but the extent to which groundwater is a mercury source to specific storm drains is not well known. There are no known mercury-contaminated large springs or extensive seepage areas that enter UEFPC (aside from Big Springs via the BSWTS and Outfall 51) and, therefore, no known mercury groundwater sources directly entering the creek. If there are low-level inputs, they are too small to be observed from changes in mercury in water. Any karst system discharges should have a strong $\mathrm{Hg}(0)$ component that would be readily detectable above the very low concentrations of dissolved gaseous mercury in UEFPC. However, given the complexity of the subsurface environment in this area and the nature of karst geology, future construction activities have the potential to dramatically change subsurface flow paths, and future additional inputs to the creek are possible.

\subsubsection{East Plant Area Storm Drain System}

As is the case in WEMA, the storm drains themselves are sources of mercury to the creek, either by the trapping of mercury at the bottom of pipes and catch basins or via cracks in pipes that allow infiltration of contaminated groundwater. In the case of old and cracked storm drain lines, the pipe footer may be a sink or trap for mercury during base flow conditions and a source of additional flux during rain events. The footers or spaces surrounding the storm drain pipe may be an additional, separate conduit for mercurycontaminated water to the creek. The mercury interactions between the storm drain, footers, and groundwater are not well understood and represent a characterization need. Although in the east end of 
the facility individual storm drains contribute a small percentage of the total flux to the creek, there are a number of storm drains with detectable mercury that cumulatively represent about $10 \%$ of the total flux.

\subsubsection{East Plant Area Ungauged Flux}

Ungauged sources can arise from (1) the infiltration of mercury-contaminated groundwater into the surface flow, (2) dissolution of $\mathrm{Hg}(\mathrm{II})$ and $\mathrm{Hg}(0)$ from within the streambed, and (3) desorption/dissolution/resuspension of mercury from stream-bank soils that slough off into the creek. Stream-bank and sediment sources contribute about a quarter of the total flux into UEFPC during base flow conditions. Although mercury is found at elevated concentrations in almost all earthen banks and sediment in UEFPC, the primary source of ungauged mercury flux to creek water during base flow is a highly contaminated sediment zone upstream of Outfall 109. Beads of mercury have been observed along with high concentrations of dissolved mercury within the gravel substrate. Recent studies suggest that surface flow from flow augmentation enters the contaminated streambed to eventually re-enter the surface flow at much higher mercury

\section{Key Point:}

Additional

characterization is

needed to better

quantify the significance

of mercury inputs from

preferred subsurface

flows paths and other

ungauged flux sources. concentrations downstream (Southworth et al. 2009; Southworth et al. 2010a).

A recent study of wet-weather export of mercury from the EFPC watershed found that most mercury exported from the watershed under high flow originated from erosion of stream banks and streambed deposits downstream from the Y-12 facility (Southworth et al. 2010b). Virtually all mercury exported under these conditions was particle-associated, with the dissolved (filter-passing) mercury concentration remaining unchanged in turbid versus clear water. Although wet-weather flows appear to account for most of the total mercury export from the watershed, the continued base flow input of dissolved mercury originating within Y-12 sustains the day-to-day exposure of aquatic life in the stream.

\subsubsection{Instream Processes}

The conceptual model is focused on major sources and transport pathways, but some understanding of instream processes is relevant to the issue of downstream transport, and a brief summary is provided here. If EFPC is depicted as originating where it exits the Y-12 storm drain network (N/S pipe), these headwaters contain about 700-1000 ng/L dissolved $\mathrm{Hg}(\mathrm{II})$. The concentration is immediately diluted to around $200 \mathrm{ng} / \mathrm{L}$ by flow management, and the dissolved mercury reacts with the suspended solids in the water and the streambed biofilm. One kilometer downstream at Station 8, it is 70\% particle-associated, and at Station 17 it is 90\% particle-associated. Within the Y-12 Complex downstream from the N/S pipe, EFPC picks up additional waterborne mercury from diffusion/advection of streambed pore water, various outfalls, erosion of stream-bank contamination, and possibly other unidentified external and instream sources as discussed above.

Total mass flux of inorganic mercury in EFPC is dominated by the transport of particle-associated mercury. Mercury-enriched particulates are detained in the streambed as they gradually wash through the system, with most of the mercury being on the silt/claysized particles. Fine particles are retained in the biofilm (periphyton) coating that covers hard surfaces of the streambed and within gravel reaches of the stream. These two habitats contain a substantial inventory of stored mercury that may be transported during high-flow events and accumulated at lower flows. Because of the high partitioning $\left(\mathrm{K}_{\mathrm{d}}\right)$ between aqueous and solid phases, these materials

\section{Key Point:}

Contaminated sediments in

East Fork Poplar Creek act as a distributed or secondary source zone for mercury. This mercury is subject to release and/or redistributed under a variety of conditions. The stream sediments continue to be a significant input of mercury to the stream. 
act to buffer water column and pore water concentrations of dissolved mercury. Based on data from a 1996 study of sediment transport in UEFPC, at that time there appeared to be about $86 \mathrm{~kg}$ of mercury in streambed particulates in the reach from the N/S pipe to Lake Reality. Although large, this inventory would have been entirely removed (or replaced) at mercury export rates typical of UEFPC (roughly 10 $\mathrm{kg} /$ year) over the decade since the study was conducted.

Dissolved inorganic mercury is assumed to be the form of mercury that acts as a direct precursor for the formation of methylmercury by microorganisms (or, to a lesser extent, by abiotic processes likely to involve extracellular release products from microorganisms) (Benoit et al. 2003). Methylation is carried out by sulfur- and iron-reducing microorganisms and is most clearly associated with redox transition zones, such as lake sediments, where aerobic conditions grade into anaerobic zones (Gilmour et al. 1991). Dissolved inorganic mercury is delivered to the sites of methylation from the water column and/or from mercury-contaminated particulates within the streambed (Brigham et al. 2009). A good understanding of the relative roles and importance of these two sources in the production of methylmercury is vital to determining the appropriate course for actions intended to reduce mercury bioaccumulation. 


\section{CONCLUSIONS AND RECOMMENDATIONS}

Based on the current conceptual understanding of mercury sources, transport, and flux at the Y-12 Complex and UEFPC, the authors offer the following conclusions and recommendations for environmental management decision making relative to the mercury issue.

\section{Current Conditions}

- Of the known mercury inputs into UEFPC, Outfall 200 is by far the most important current source of mercury to creek water. Depending on flow conditions, Outfall 200 represents approximately 70-80\% of the flux observed at Station 17. This is a change from 10 years ago when Outfall 200 was thought to represent approximately $20 \%$ of the flux to Station 17.

- Base flow mercury flux from some WEMA outfalls (especially Outfall 163) and Outfall 200 appears to have increased from pre-ROD levels in 2000. However, flux is highly variable and weather/flow dependent, and higher fluxes have been observed before and after the 2000 assessment.

- The current assessment is that flux from Outfalls 150, 160, 163, and 169 accounts for most, if not all, of the flux at Outfall 200. Sediments within the N/S pipe have not been sampled for mercury, but are unlikely to be a major source.

- Under base flow conditions, stream sediment provides the second most important continuing source of mercury into creek water (upstream of Outfall 109). Flow management appears to have increased flux from this sediment source.

- Shallow groundwater near Big Springs is a known and substantial mercury source that highlights the need for continued operation of BSWTS. The primary groundwater sources to the BSWTS, whether originating from 81-10, the WEMA area, or the Alpha 2 area, are not well understood.

- BSWTS has been successful at removing approximately 2-3 g/d of mercury that entered UEFPC prior to BSWTS start-up, as well as substantially reducing the average mercury concentration in the creek. Over much of its operation, BSWTS has removed a much higher amount of mercury from groundwater than was anticipated.

- Little direct evidence is available to establish that high mercury soil areas at 81-10 and Alpha 2, or low mercury sites at the far west end of the facility in or around the Old Salvage Yard, are sources of mercury to the creek. Relative to known sources of mercury within WEMA storm drains and stream sediments, mercury flux to the creek from these sites is likely to be small if present.

\section{Recommendations - Transport Pathways}

- Transport pathway sampling is needed that includes measurement of mercury concentration and flow under base flow and storm flow conditions at multiple sites at the same time.

- Accuracy of flow measurements is an uncertainty in calculations of flux. Better techniques are needed to measure flow within difficult-to-access storm drains. Use of metered dye (fluorescein) and fluorescence spectrometry might be helpful.

- There is significant uncertainty associated with shallow groundwater movement near contaminated buildings and interactions with preferred flow paths and subsurface infrastructure. Further study is 
needed to understand interactions between storm drains, footers/backfill, and surrounding soil. Most wells at Y-12 were not designed to help understand these processes.

- Continued sampling of WEMA storm drains during and after WEMA cleanout activities is important in assessing remedial performance. The feasibility studies for the UEFPC interim control actions assumed that hydraulic isolation, sewer relining, and capping actions within WEMA would result in an approximately 50\% reduction of mercury flux, from 1.8 to $0.9 \mathrm{~g} / \mathrm{d}$. Current measured fluxes from WEMA prior to relining and cleanout activities are substantially higher (5-15 g/d), but the WEMA storm drain action appears well targeted to make a difference in mercury flux to the creek.

- The conceptual model for mercury identifies the major sources and transport pathways for mercury at Y-12, but the many small sources of mercury identified in the model may also be important if the goal is to reach very low mercury levels in stream water and fish. Additional mercury flux information is needed for these sites, especially during high flow conditions.

- Although the focus of the conceptual model evaluations was on Domain I and II transport pathways, the downstream instream processes must be a part of the overall mercury remediation strategy and research at the site. Ungauged downstream flux is not well understood and needs further study.

- Characterization activities are needed to define the nature and extent of potential or poorlyunderstood sources, including the forms and mobility of mercury.

\section{Recommendations - Conceptual Models}

- The use of conceptual models is recommended to consolidate complex data and emphasize key mercury processes at Y-12, providing a more nuanced and robust understanding of the site. These conceptualizations can be structured to support cleanup and reconfiguration efforts and assist DOE in developing a focused and effective applied science research portfolio to address key uncertainties and data gaps.

- In the complex mercury environment of the Y-12 Complex and UEFPC, conceptual models should be regularly updated for effective environmental management decision making.

- Comparisons with past mercury conceptual models and mercury dynamics are useful in understanding how conditions and assumptions have changed over time.

- Assumptions, uncertainties, or unknowns identified in the conceptual model should be evaluated by field studies and/or process models that can help in making informed remedial decisions as well as understanding potential long-term impacts of remedial actions.

- Site-specific conceptual models and summaries of existing data and data gaps for individual source areas (buildings, drains, etc.) and/or conveyances are needed.

- In addition to the above recommendations, research is recommended to develop a more robust conceptual model for Y-12 that includes

- evaluation of mercury speciation within the facility, using new tools to detect and quantify elemental mercury;

- $\quad$ evaluation of the importance of mercury concentration versus flux on downstream media and bioavailability; 
- $\quad$ evaluation of the importance of base flow versus storm flow flux; and

- understanding the connections between concentrations of inorganic mercury precursors and methylmercury concentration, bioavailability, and bioaccumulation. 



\section{REFERENCES}

Amyot, M., F.M.M. Morel, and P. Ariva. 2005. "Dark Oxidation of Dissolved and Liquid Elemental Mercury in Aquatic Environments.” Environmental Science and Technology 39:110-114.

Benoit, J., C.C. Gilmour, A. Heyes, R. Mason, and C. Miller. Geochemical and biological controls over methylmercury production and degradation in aquatic systems. In Biochemistry of Environmental Important Trace Elements; Chai, Y., Braids, O. C., Eds.; American Chemical Society: Washington, DC, 2003; Vol. ACS Symposium Series \#835, pp 262-297.

BJC (Bechtel Jacobs Company LLC). 2000. Mercury Abatement Report for the U.S. Department of Energy Oak Ridge Y-12 Plant for Fiscal Year 2000, Oak Ridge, Tennessee. BJC/OR-782. Prepared by Environmental Sciences Division, Oak Ridge National Laboratory, Oak Ridge, TN.

BJC (Bechtel Jacobs Company LLC). 1999. Mercury Abatement Report for the U.S. Department of Energy Oak Ridge Y-12 Plant for Fiscal Year 1999, Oak Ridge, Tennessee. BJC/OR-422. Prepared by Environmental Sciences Division, Oak Ridge National Laboratory, Oak Ridge, TN.

BJC (Bechtel Jacobs Company LLC). 1998. Mercury Abatement Report for the U.S. Department of Energy Oak Ridge Y-12 Plant for Fiscal Year 1998, Oak Ridge, Tennessee. BJC/OR-183. Prepared by Environmental Sciences Division, Oak Ridge National Laboratory, Oak Ridge, TN.

Bogle M.A. and G.R. Southworth 1998. ORNL report to the Reduction of Mercury in Plant Effluents manager (BJC). Letter Report. Nov. 30, 1998. Oak Ridge, TN.

Brigham, M.E., D.A. Wentz, G.R. Aiken, and D.P. Krabbenhoft. 2009. "Mercury cycling in stream ecosystems. 1. Water column chemistry and transport.“ Environmental Science and Technology 43:27202725.

Brooks, S. C. and G. R. Southworth. 2011. History of mercury use and environmental contamination at the Oak Ridge Y-12 Plant. Environmental Pollution. 159 (2011) 219-228.

ChemRisk. 1999. Mercury Releases from Lithium Enrichment at the Oak Ridge Y-12 Plant-A Reconstruction of Historical Releases and Off-site Doses and Health Risks, Task 2 Report of the Oak Ridge Dose Reconstruction, Volume 2. Oak Ridge: Tennessee Department of Health.

DOE (Department of Energy). 2011. 2010 Remediation Effectiveness Report for the U.S. Department of Energy Oak Ridge Reservation, Oak Ridge, Tennessee. DOE/OR/01-2491\&D0. Department of Energy, Office of Environmental Management, Oak Ridge, TN.

DOE (Department of Energy). 2010a. 2009 Remediation Effectiveness Report for the U.S. Department of Energy Oak Ridge Reservation, Oak Ridge, Tennessee. DOE/OR/01-2393\&D1. Department of Energy, Office of Environmental Management, Oak Ridge, TN.

DOE (Department of Energy). 2010b. Remedial Design Report/Remedial Action Work Plan for the West End Mercury Area (WEMA) Storm Sewer Remediation Project at the Y-12 National Security Complex, Oak Ridge, Tennessee. DOE/OR/01-2447\&D2. Oak Ridge, TN.

DOE (Department of Energy). 2008. Major Risk Factors, Integrated Facility Disposition Project (IFDP), Oak Ridge, Tennessee. External Technical Review (ETR) Report. 
DOE (Department of Energy). 2004. Remediation Effectiveness Report for the U.S. Department of Energy Oak Ridge Reservation, Oak Ridge, Tennessee. DOE/OR/01-2133\&D1. Department of Energy, Office of Environmental Management, Oak Ridge, TN.

DOE (Department of Energy). 2002. Record of Decision for Phase I Interim Source Control Actions in the Upper East Fork Poplar Creek Characterization Area, Oak Ridge, Tennessee. DOE/OR/011951\&D3. Oak Ridge, TN.

DOE (Department of Energy). 2001. Treatability Study Report for Evaluating the Upper East Fork Poplar Creek Hydraulic Connection at the Y-12 National Security Complex, Oak Ridge, Tennessee. DOE/OR/01-1963\&D1. Department of Energy, Office of Environmental Management, Oak Ridge, TN. Prepared by Environmental Sciences Division, Oak Ridge National Laboratory and Tetra Tech, Inc.

DOE (Department of Energy). 2000. Addendum to Feasibility Study for the Upper East Fork Poplar Creek Characterization Area at the Oak Ridge Y-12 Plant, Oak Ridge, Tennessee. DOE/OR/O11747\&D3/A3. Oak Ridge, TN.

DOE (Department of Energy). 1998. Report on the Remedial Investigation of the Upper East Fork Poplar Creek Characterization Area at the Oak Ridge Y-12 Plant. DOE/OR/01-1641/V1-V4\&D2. Oak Ridge, TN.

DOE (Department of Energy). 1997. FY 1997 Oak Ridge Reservation Integrated Water Quality Program Plan, Oak Ridge, Tennessee. DOE/OR/01-1656. Department of Energy, Office of Environmental Management, Oak Ridge, TN. Prepared by Science Applications International Corporation, Oak Ridge, TN.

DOE (Department of Energy). 1996a. Preliminary Assessment of the Ecological Risks to Wide-ranging Wildlife Species on the Oak Ridge Reservation - 1996 Update. DOE/OR/01-1407\&D2. Department of Energy, Office of Environmental Management, Oak Ridge, TN. Prepared by Environmental Sciences Division, Oak Ridge National Laboratory, Oak Ridge, TN.

DOE (Department of Energy). 1996b. Baseline and Postremediation Monitoring Program Plan for the Lower East Fork Poplar Creek Remedial Action Project, Oak Ridge, Tennessee. Y/ER-262/R1.

Department of Energy, Office of Environmental Management, Oak Ridge Y-12 Plant, Oak Ridge, TN. Prepared by Science Applications International Corporation, Oak Ridge, TN.

DOE (Department of Energy). 1995. Preliminary Assessment of the Ecological Risks to Wide-ranging Wildlife Species on the Oak Ridge Reservation. DOE/OR/01-1407\&D1. Oak Ridge, TN.

DOE (Department of Energy). 1994. East Fork Poplar Creek/Sewer Line Beltway Remedial Investigation Report, Vol. III, Sections 6-9. DOE/OR/02-1119\&D0. Department of Energy, Radian Corporation. Prepared by Science Applications International Corporation, Oak Ridge, TN.

Energy Systems (Lockheed Martin Energy Systems, Inc.) 1999. Determination of Site-Specific Aqueous Concentration Goals for Controlling Mercury Bioaccumulation in Fish in East Fork Poplar Creek:

Results of Studies Undertaken by the Y-12 Biological Monitoring and Abatement Program (BMAP) at the Oak Ridge Y-12 Plant, Oak Ridge, Tennessee. BJC/OR-272. Oak Ridge, TN.

Energy Systems (Lockheed Martin Energy Systems, Inc.) 1997. Mercury Abatement Report for the U.S. Department of Energy Oak Ridge Y-12 Plant for Fiscal Year 1997. Y/ER-297. Prepared by Environmental Sciences Division, Oak Ridge National Laboratory, Oak Ridge, TN. 
Energy Systems (Lockheed Martin Energy Systems, Inc.) 1996. Mercury Abatement Report for the U.S. Department of Energy Oak Ridge Y-12 Plant for Fiscal Year 1996. Y/ER-277. Prepared by Environmental Sciences Division, Oak Ridge National Laboratory, Oak Ridge, TN.

Geraghty \& Miller. 1985. The Relation of Ground Water to Mercury Migration at the Y-12 Plant and the Hydrologic Effects of Proposed Clean-up Measures. Final report. Y/SUB/8585-00206C/5. Prepared for Martin Marietta Energy Systems by Geraghty \& Miller Inc., Ground-Water Consultants, Oak Ridge, TN.

Gentile, J.H., M.A. Harwell, W. Cropper, Jr., C.C. Harwell, D. DeAngelis, S. Davis, J.C. Ogden, and D. Lirman. 2001. "Ecological conceptual models: A framework and case study on ecosystem management for South Florida sustainability.” The Science of the Total Environment 274:231-253.

Gilmour, C.C. and E.A. Henry. 1991. "Mercury methylation in aquatic systems affected by acid deposition.” Environmental Pollution 71:131-69.

Henke, K.R., M.A. Bogle, and R.R. Turner. 1996. The Subsurface Hydrology Around Building 9201-2: Results of the July 1994 Water Level Recovery Test, Oak Ridge Y-12 Plant, Oak Ridge, Tennessee. Y/ER263. Oak Ridge Y-12 Plant, Oak Ridge, TN.

Lind, D. 2009. D. Lind (B\&W Y-12) personal communication to Mark Peterson (UT-Battelle). Oak Ridge, TN. December 17, 2009.

Looney, B.B., C.A. Eddy-Dilek, R. Turner, G.R. Southworth, M.K. Peterson, and A.V. Palumbo. 2008. Recommendations to Address Technical Uncertainties in Mitigation and Remediation of Mercury Contamination at the Y-12 Plant, Oak Ridge, Tennessee. WSRC-STI-2008-00212. Savannah River National Laboratory, Aiken, SC.

MDN (Mercury Deposition Network). 2007. Mercury deposition data and maps, available at http://nadp.sws.uiuc.edu/.

Moline, G.R., G.R. Southworth, M.A. Bogle, D.B. Watson, and S. Field. 1998. An Investigation of Increased Mercury Loading in Upper East Fork Poplar Creek During Flow Management: Probable Causes and Links to Subsurface Hydrology. ORNL/TM-13644. Oak Ridge National Laboratory, Oak Ridge, TN.

Moline, G.R., G.R. Southworth, M.A. Bogle, and S. Field. 2001. "Upper East Fork Poplar Creek hydrologic assessment: Tracer test result.” Letter Report. Oak Ridge, TN.

Norris, M.J. 1993. Mercury Abatement at Y-12: A Progress Report. Y/ER-116, Martin Marietta Energy Systems, Inc., Oak Ridge, TN.

ORISE (Oak Ridge Institute for Science and Education). 2010. Characterization Report for the 81-10 Area in the Upper East Fork Poplar Creek Area at the Oak Ridge Y-12 National Security Complex, Oak Ridge, Tennessee. DOE/OR/01-2485\&D1. Oak Ridge, TN.

Peterson, M.J., M.S. Greeley Jr., T.J. Mathews, G.W. Morris, W.K. Roy, M.G. Ryon, J.G. Smith, and G.R. Southworth. 2009. Y-12 National Security Complex Biological Monitoring and Abatement Program 2008 Calendar Year Report. http://www1.y12.doe.gov/search/library/documents/pdf/mswie-100719.pdf 
Rossabi, J.B., D. Riha, C.A. Eddy-Dilek, B.B. Looney, and W.K. Hyde. 2003. "Recent advances in characterization of vadose zone dense non-aqueous phase liquids (DNAPL) in heterogeneous media." Environmental \& Engineering Geoscience 9:25-36.

Rothschild, E.R., R.R. Turner, S.H. Stow, M.A. Bogle L.K. Hyder, O.M. Sealand, and H.J. Wyrick. 1984. Investigation of Subsurface Mercury at the Oak Ridge Y-12 Plant. ORNL/TM-9092. Oak Ridge National Laboratory, Oak Ridge, Tennessee.

Southworth, G., M.A. Bogle, S. Brooks, L. Liang, M. Peterson, B. Spalding, D. Watson, F. Zhang, and T. Abraham. 2010a. Evaluation of New Options for Reducing Mercury Release at the Y-12 National Security Complex. ORNL/TM-2010/33. Oak Ridge National Laboratory, Oak Ridge, Tennessee.

Southworth, G., M. Greeley, M. Peterson, K. Lowe, and R. Ketelle. 2010b. Sources of Mercury to East Fork Poplar Creek Downstream from the Y-12 National Security Complex: Inventories and Export Rates. ORNL/TM-2009/231. Oak Ridge National Laboratory, Oak Ridge, Tennessee.

Southworth, G., S. Brooks, M. Peterson, M.A. Bogle, C. Miller, M. Elliott, and L. Liang. 2009. Controlling Mercury Release from Source Zones to Surface Water: Initial Results of Pilot Tests at the Y12 National Security Complex. ORNL/TM-2009/035. Oak Ridge National Laboratory, Oak Ridge, Tennessee.

Southworth, G.R., M.K. Peterson, M.A. Bogle, and M. McCracken. 2007. December 2007 synoptic survey of $\mathrm{Hg}$ concentrations in storm drains and throughout the length of EFPC. Letter Report. Oak Ridge National Laboratory, Oak Ridge, TN.

Suter, G.W., II. 1999. "Developing conceptual models for complex ecological risk assessments.” Human and Ecological Risk Assessment 5:375-396.

Turner, R.R., G.E. Kamp, M.A. Bogle, J. Switek, and R. McElhaney. 1985. Sources and discharges of mercury in drainage waters at the Oak Ridge Y-12 Plant. Y/TS-90. Oak Ridge Y-12 Plant, Oak Ridge, TN.

UCC (Union Carbide Corporation). 1983a. Mercury at the Y-12 Plant - A Summary of the 1983 UCC-ND Task Force Study. Y/EX-23. Oak Ridge Y-12 Plant, Oak Ridge, TN.

UCC (Union Carbide Corporation). 1983b. Characterization of Y-12 Storm Drain System and Effluents Intersecting in East Fork Poplar Creek. YSE-44. Oak Ridge Y-Plant, Oak Ridge, TN.

Watson, D.B., and M.A. Mueller. 2010. "Mapping Potential Preferred Pathways and Risk of Contaminant Migration with GIS.” Ground Water Monitoring \& Remediation. In review.

Young, R.M. 1987. Estimation of the Bioaccumulation of Mercury by Bluegill Sunfish in East Fork Poplar Creek - Final Report. Tennessee Valley Authority, Knoxville, TN. 


\section{APPENDIX A. COMPENDIUM OF HISTORICAL MERCURY CONCEPTUAL MODELS AND DIAGRAMS}

Select conceptual models and diagrams used to describe the mercury situation at Y-12 or East Fork Poplar Creek since 1983 are provided in this Appendix. Types of models shown herein include those describing instream processes, physical features at the Y-12 Complex, and mercury sources and transport pathways.

\section{A.1 INSTREAM PROCESSES}

Many of the conceptual models first developed in the 1980s and 1990s focused on in-stream mercury processes (Appendix A, Sect. A.1), especially food-web interactions. These early conceptual models (Figs. A.1.1-A.1.6) separated media such as soil, sediment, surface water, and biota into boxed compartments. Media linkages and food-chain pathways were indicated in these models but with little depiction of mercury chemistry, environmental factors, or physical complexities. Mercury chemistry and various environmental factors affecting cross-media interactions, bioavailability, and bioaccumulation were a major component of stream-focused conceptual models by the 2000s (Figs. A.1.7-A.1.12). The models introduced the importance of the various forms of mercury; importance of subsurface-to-surfacewater interactions; and influence of water chemistry variables, microbial community methylation/demethylation factors, and mercury bioavailability. These instream models were not spatially explicit or designed to show the magnitude of mercury from various sources. They have been particularly useful, however, in showing where there are research needs; for instance, Fig. A.1.9 illustrates the importance of groundwater-to-sediment-to-surface-water interactions, and Fig. A.1.11 highlights opportunities for EM-32 mercury remediation research.

\section{A.2 PHYSICAL FEATURES AT THE Y-12 COMPLEX}

The physical features within the Y-12 Complex are important considerations in how mercury is transported to the creek. Conceptual models that focus on mercury-related infrastructure and subsurface dynamics are shown in Appendix A, Sect. A.2, and all are characterized using cross-sectional diagrams. Cross-sectional diagrams provide an opportunity to visually depict the various subsurface, geological, hydrological, and infrastructure/building interactions affecting mercury transport (Figs. A.2.1-A.2.4). Much like conceptual models highlighting in-stream processes, conceptual models highlighting physical subsurface features are rarely spatially explicit. The focus on physical processes leaves little opportunity for indicating mercury chemistry or quantities (speciation, concentration, or flux). The conceptual models focused on physical features are useful in indicating the complexity of the Y-12 buildings, infrastructure, and subsurface environment, which affects mercury transport.

\section{A.3 SOURCES AND TRANSPORT PATHWAYS}

Conceptual models and diagrams focused on mercury sources and transport pathways within the Y-12 Complex are provided in Appendix A, Sect. A.3. Characteristic of these conceptual models and diagrams is the spatially explicit depiction of major sources and transport pathways. Perhaps the simplest of these kinds of depictions, which may provide the beginning basis of a conceptual model, is the reporting of mercury concentrations and flux on a map (UCC 1983b; Fig. A.3.1). Other conceptual models focusing on sources and transport pathways do not show mercury concentrations or flux but focus on indicating transport pathways between specific building sources, outfalls, and creek locations (Figs. A.3.2, A.3.5). The most rigorous conceptual models showing mercury sources and transport pathways also show the magnitude of mercury (typically in concentration or flux). Qualitative conceptual models of this type were used to evaluate the feasibility of interim source control actions for the UEFPC Feasibility Study and Record of Decision (ROD) (DOE 2000; DOE 2002) (Figs. A.3.3 and A.3.4). 



\section{A.1 INSTREAM PROCESSES}

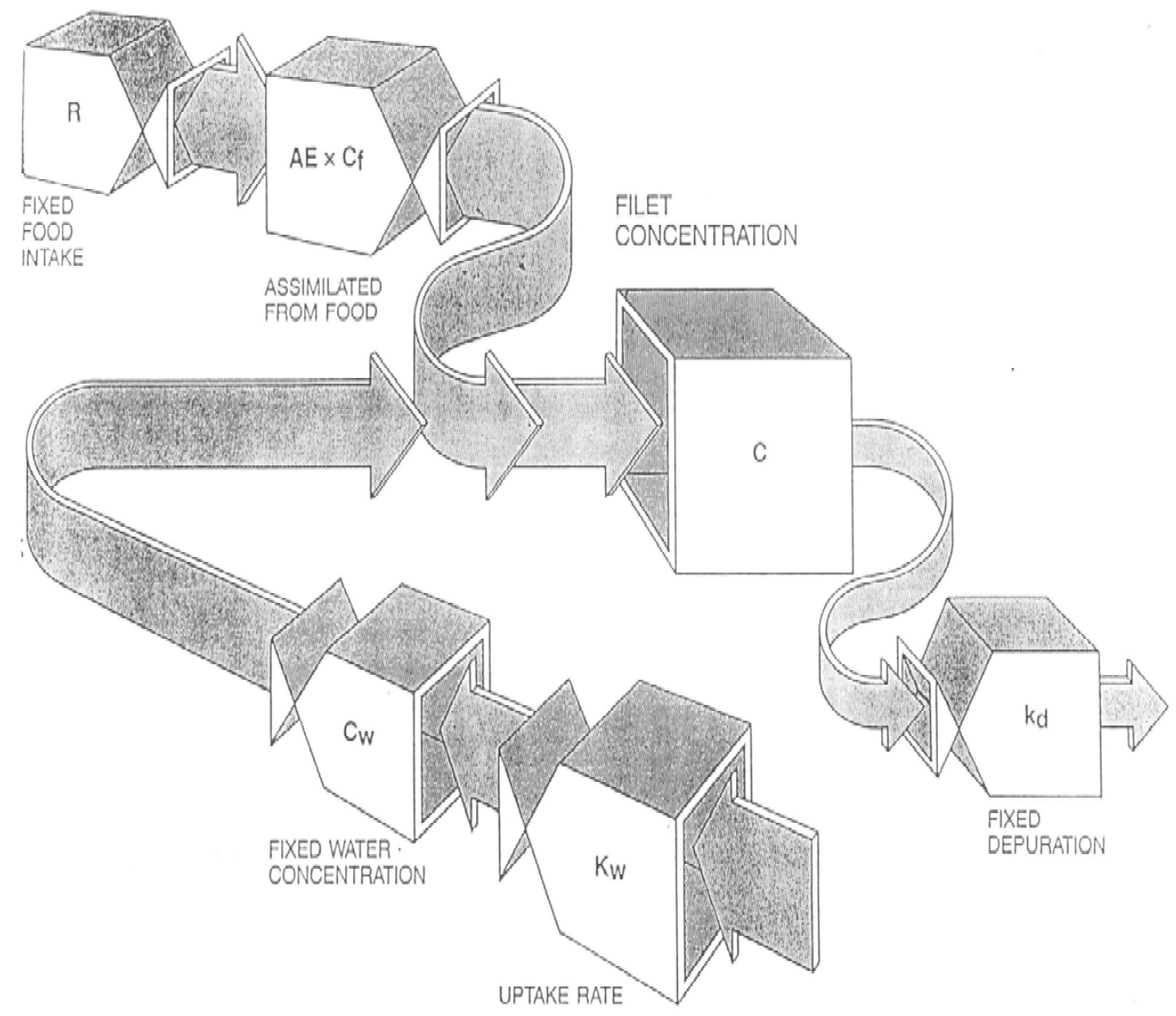

Fig. A.1.1. 1987. One compartment bioaccumulation model. Source: Young 1987. Model used to explain bioaccumulation of mercury by bluegill sunfish in East Fork Poplar Creek. 


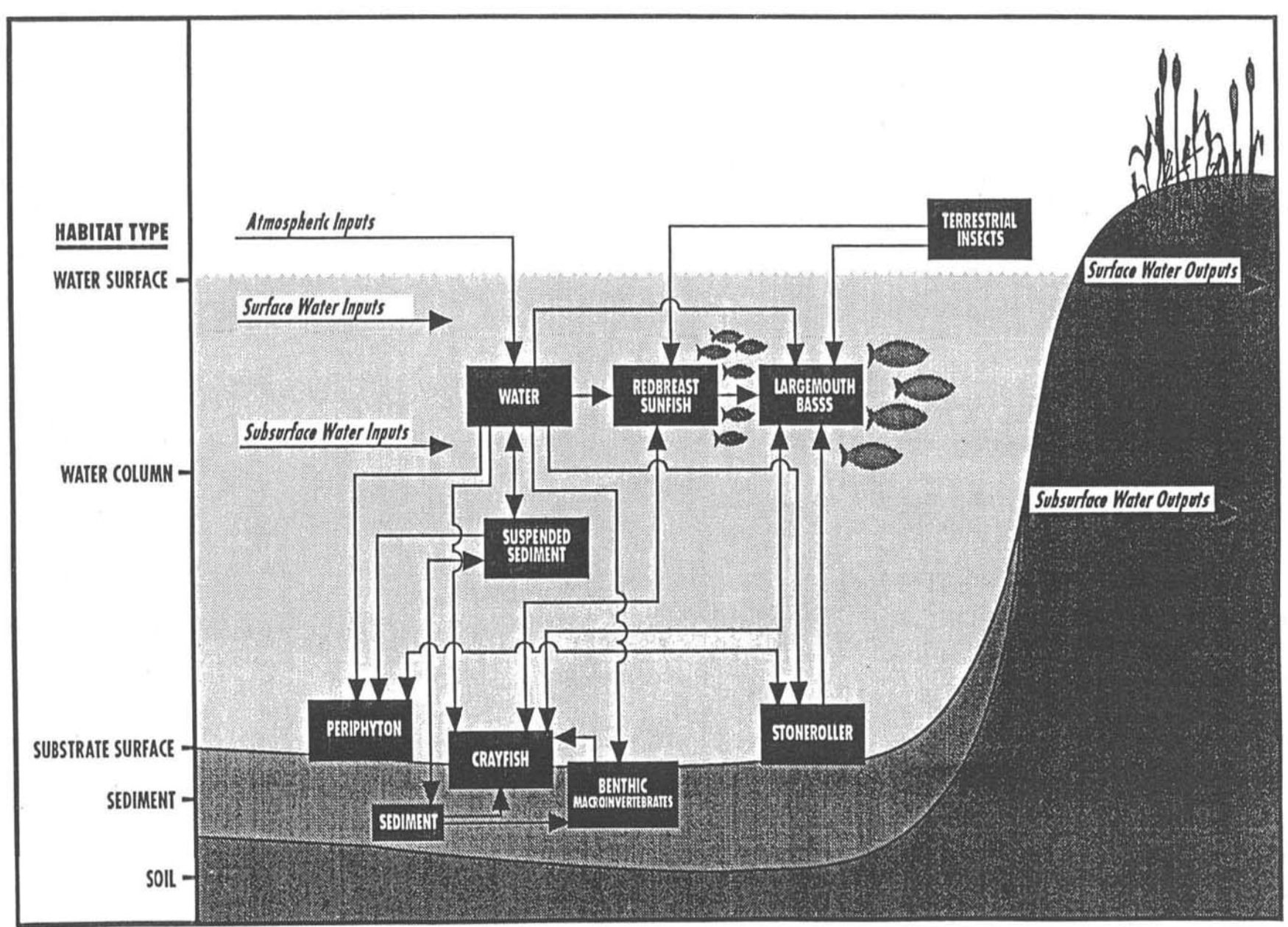

Fig. A.1.2. 1994. Simplified food web for EFPC aquatic ecosystem. Source: DOE 1994. Model used to describe instream mercury processes for the remedial investigation of East Fork Poplar Creek/Sewer Line Beltway. 


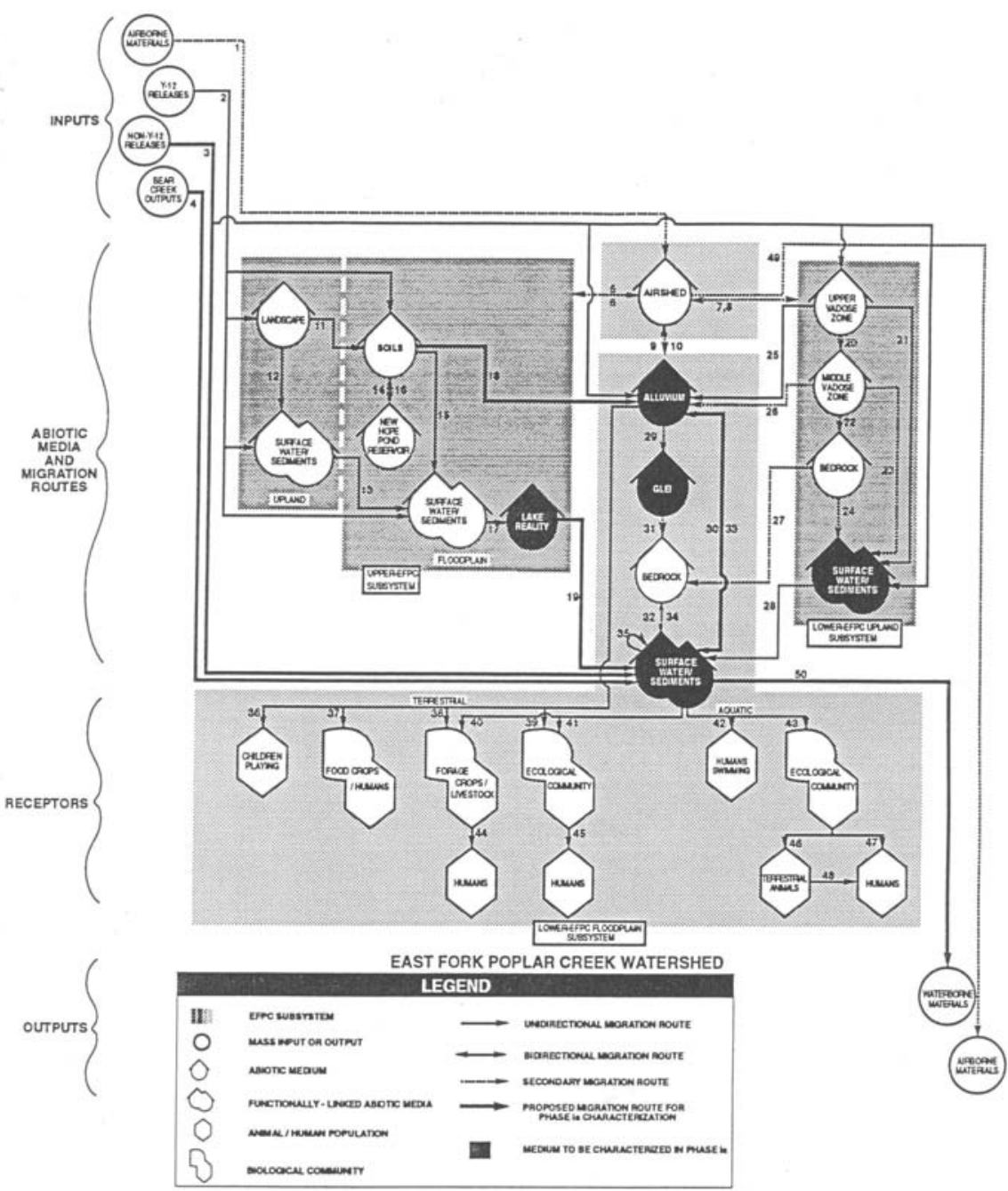

Fig. A.1.3. 1994. Conceptual model of releases from the Y-12 Plant to EFPC. Source: DOE 1994. Model used to explain instream mercury compartments and pathways for remedial investigation of East Fork Poplar Creek/Sewer Line Beltway. 


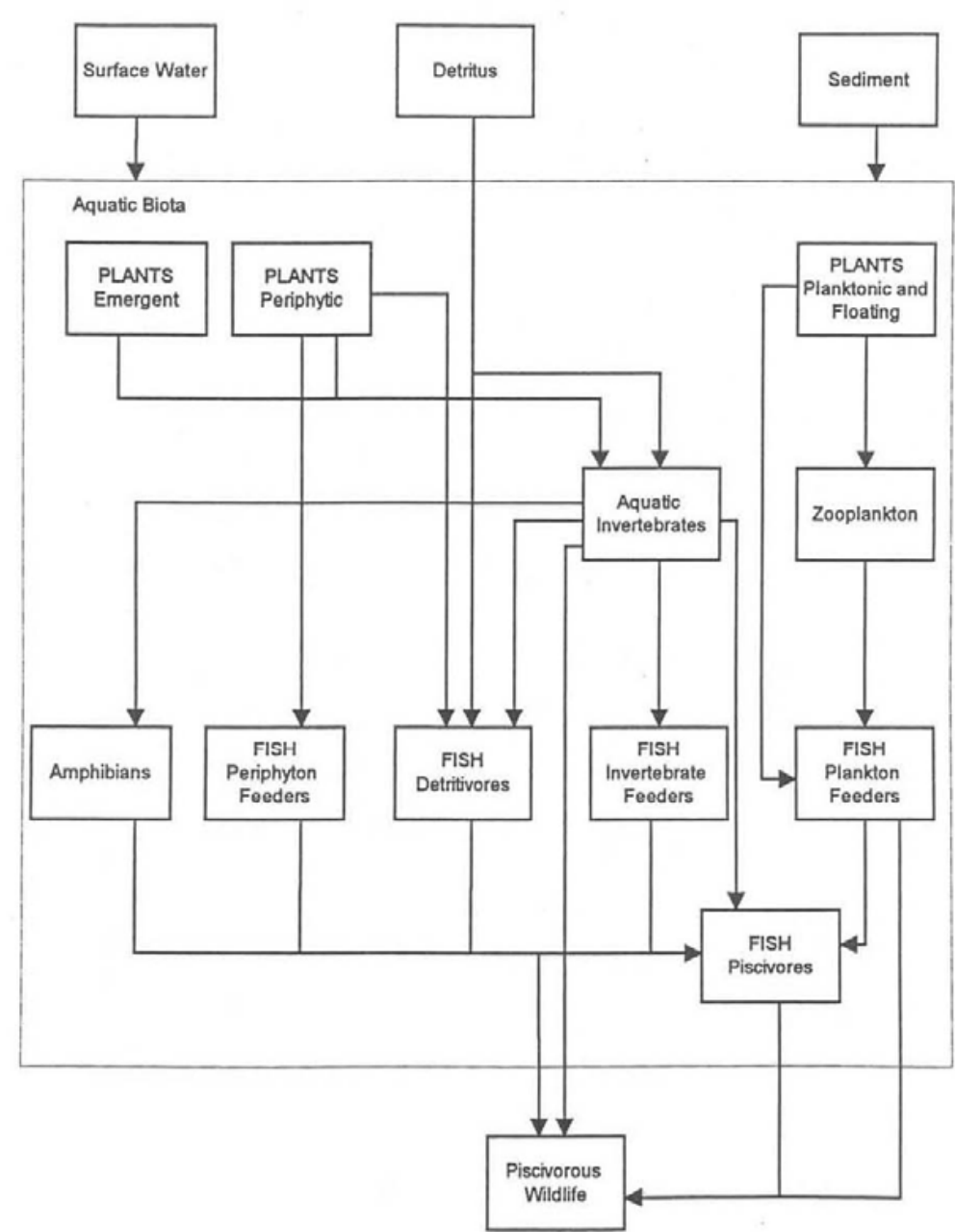

Fig. A.1.4. 1995. Conceptual model for the exposure of piscivorous wildlife to contaminants. Source: DOE 1995. Model used to describe ecological risk pathways for wide-ranging wildlife species on the Oak Ridge Reservation. 


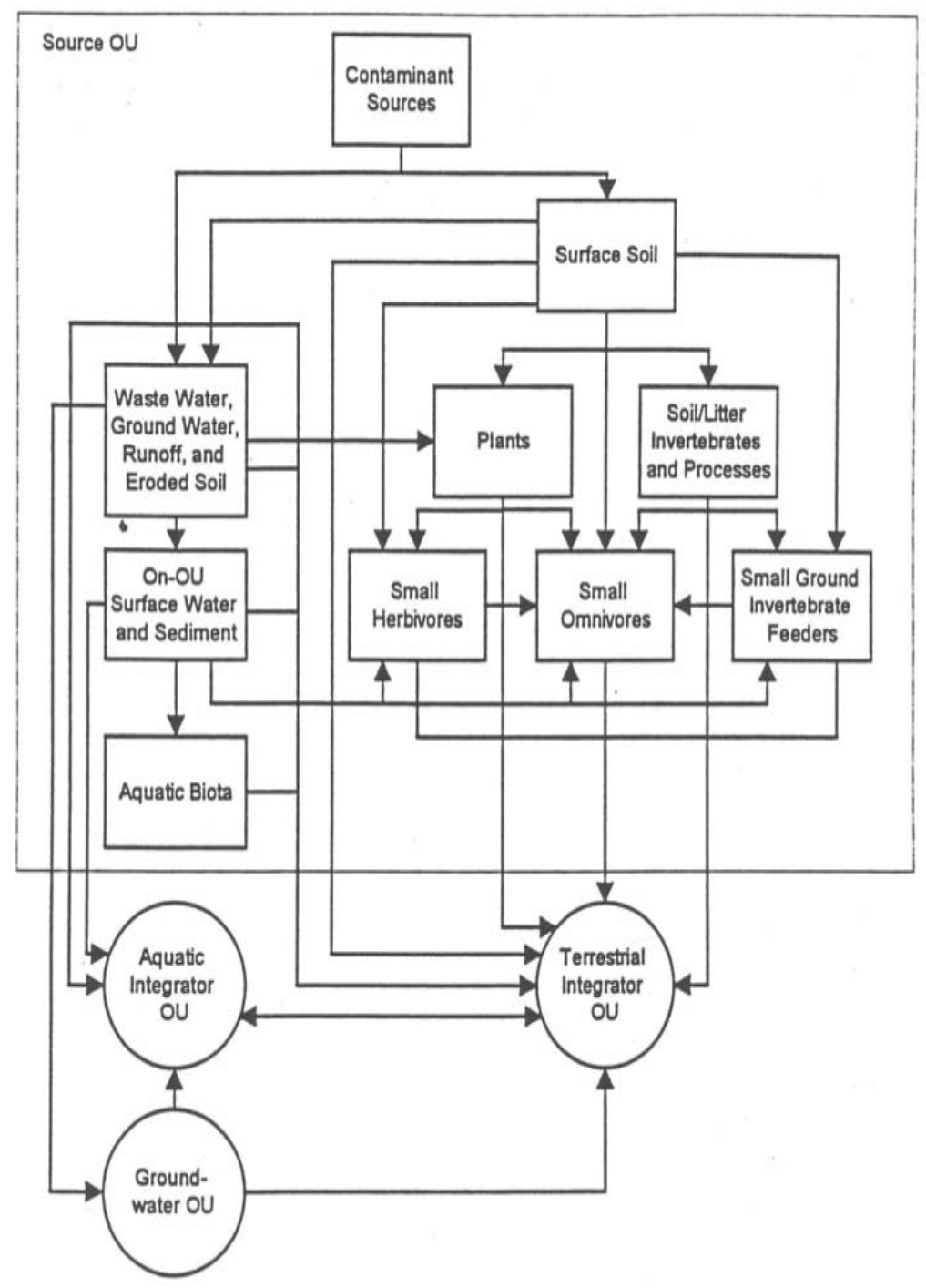

Fig. A.1.5. 1996. Conceptual model of the transfer of contaminants through a source OU and into integrator OUs. Source: DOE 1996a. Model used to describe ecological risk pathways for wide-ranging wildlife species and relationship with operable units (OUs). 


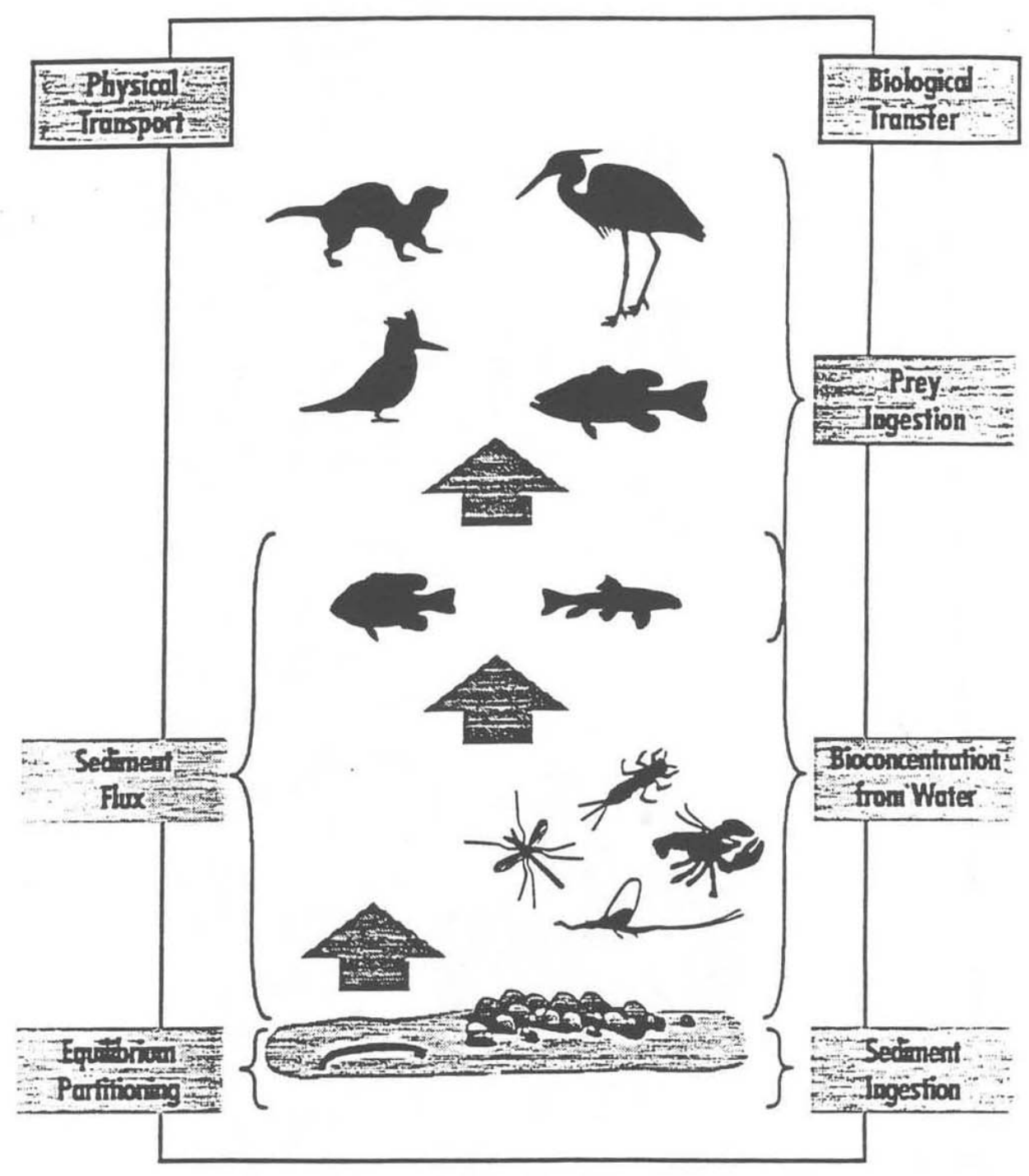

Fig. A.1.6. 1996. Flows of mercury in EFPC sediment and surface water. Source: DOE 1996b. Model used to develop a program plan for baseline and postremediation monitoring as part of the Lower East Fork Poplar Creek Remedial Action Project. 


\section{Simple diagram of key $\mathrm{Hg}$ chemistry processes}

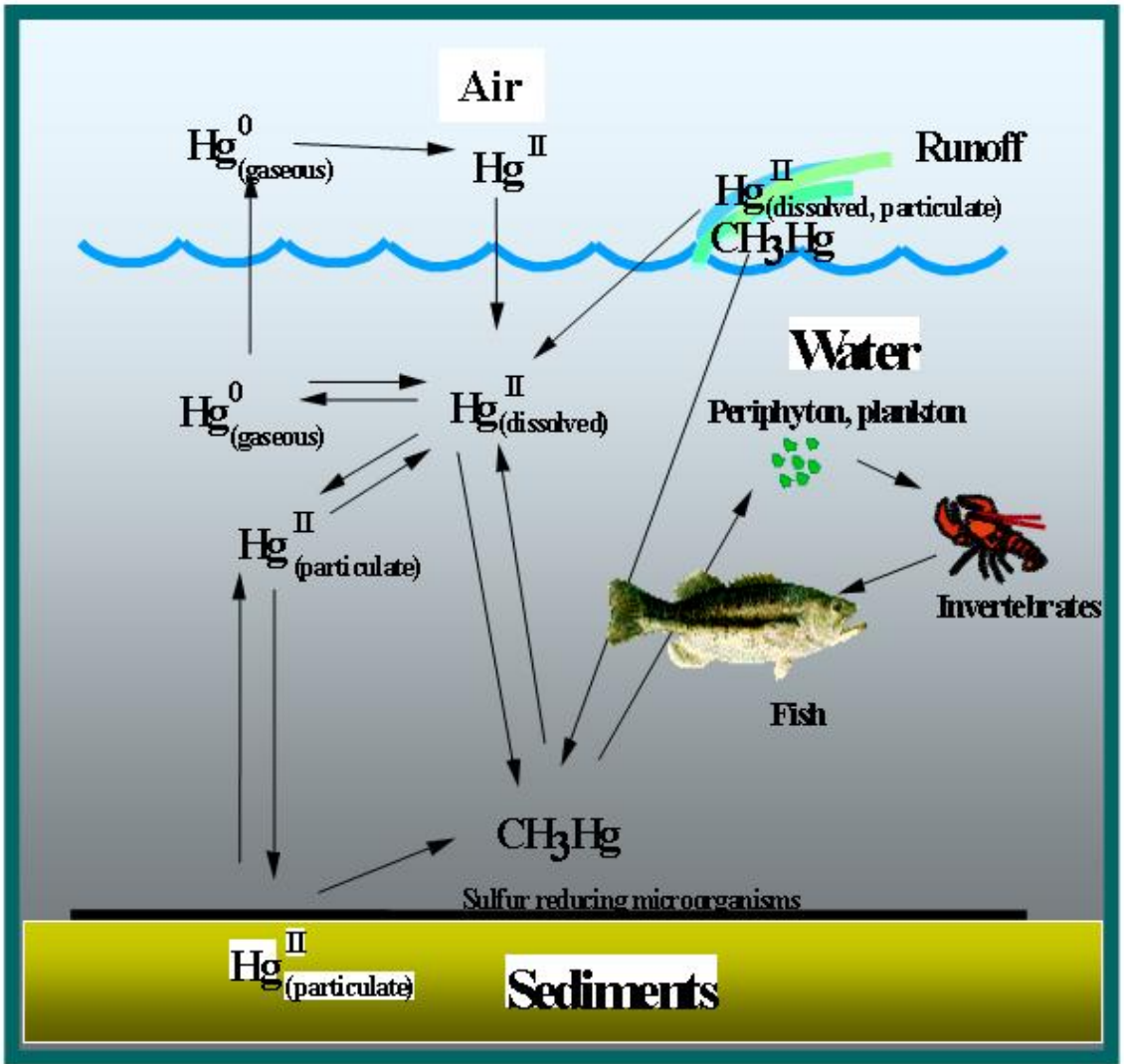

M Peterson

Fig. A.1.7. 2002. Diagram of key mercury chemistry processes. Source: Peterson and Southworth (Oak Ridge National Laboratory), unpublished. Used to describe mercury chemistry processes in stream and reservoir systems. 


\section{Addressing the source term only a piece of the puzzle}

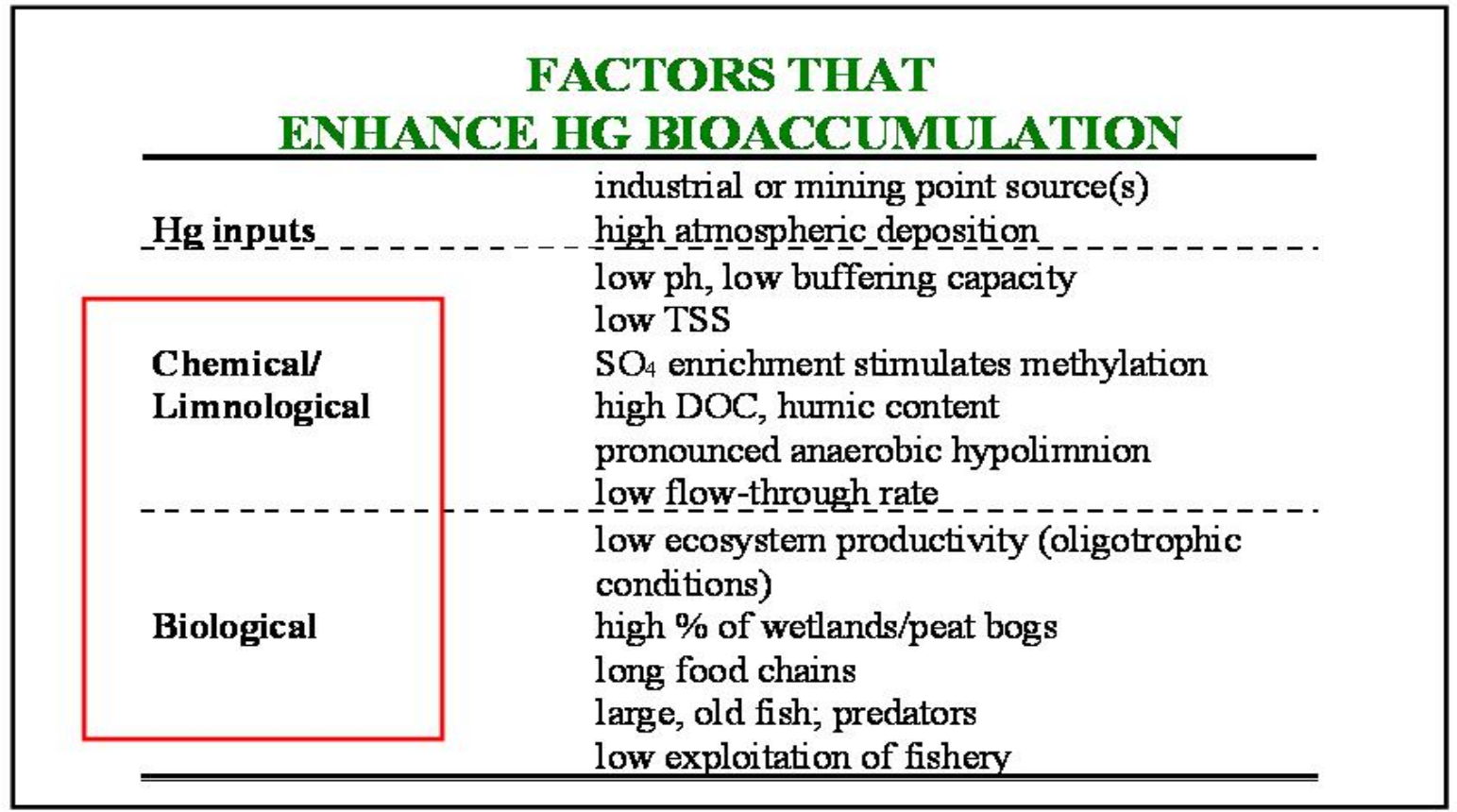

ORNL-developed framework/checklist for Federal Energy Regulatory Commission staff evaluations of mercury issues in reservoirs

Fig. A.1.8. 2002. Factors that enhance mercury bioaccumulation. Source: Peterson and Southworth (Oak Ridge National Laboratory), unpublished. Diagram used to highlight the importance of chemical and biological processes on bioaccumulation. 


\section{Evolving Conceptual Model}

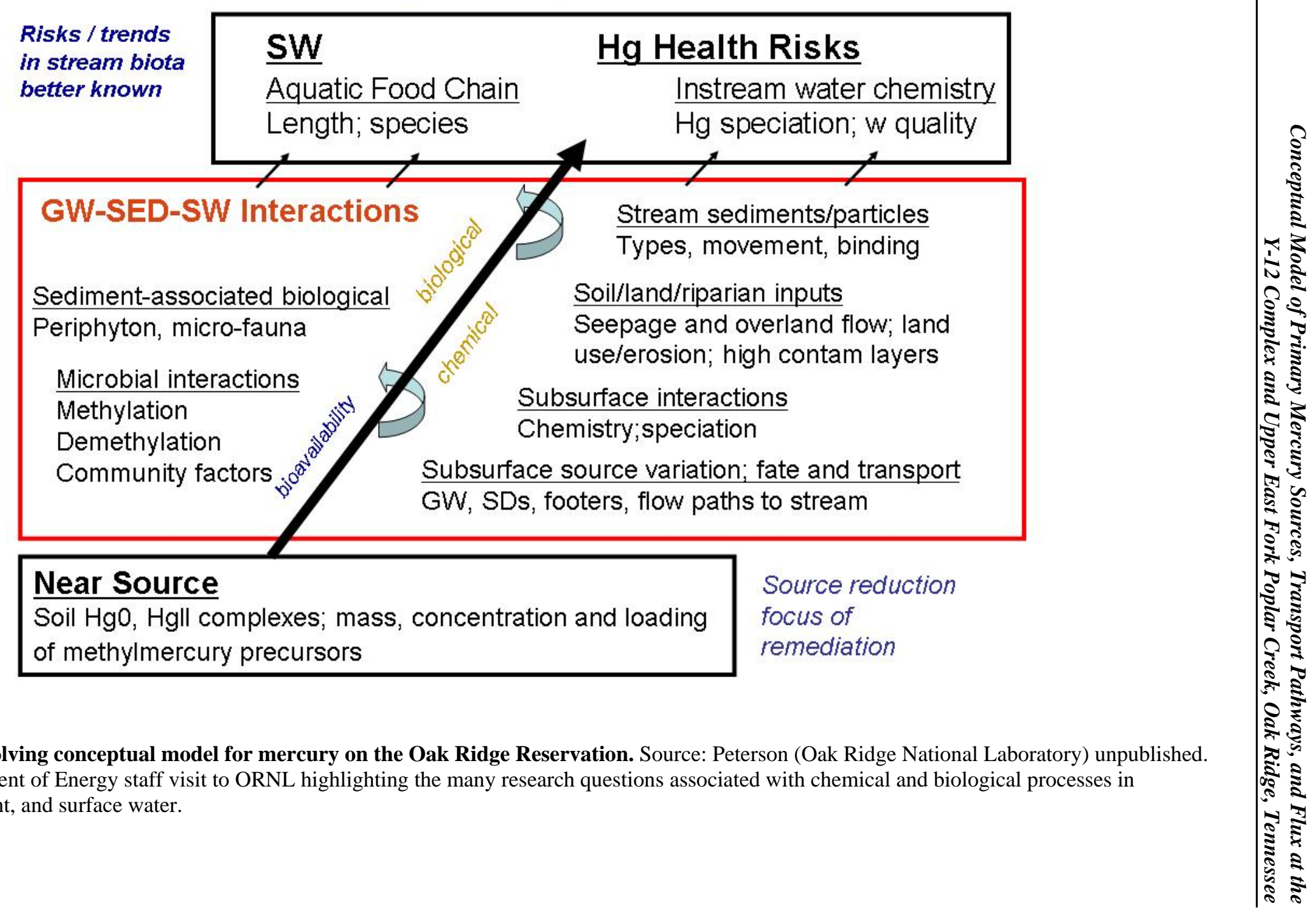

Fig. A.1.9. 2007. Evolving conceptual model for mercury on the Oak Ridge Reservation. Source: Peterson (Oak Ridge National Laboratory) unpublished. Presented at Department of Energy staff visit to ORNL highlighting the many research questions associated with chemical and biological processes in groundwater, sediment, and surface water. 


\section{EFPC Mercury Transport/Accumulation Model}

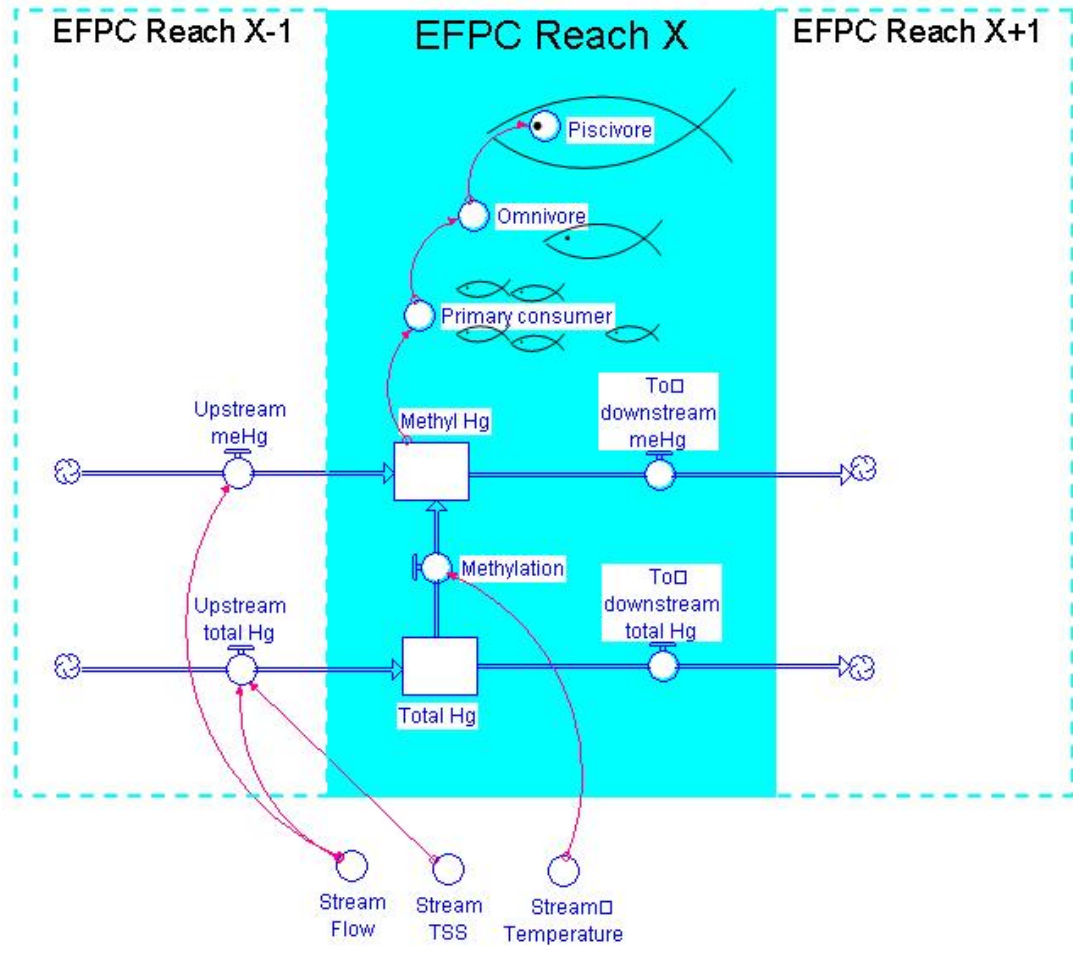

External factors affect exchange rates

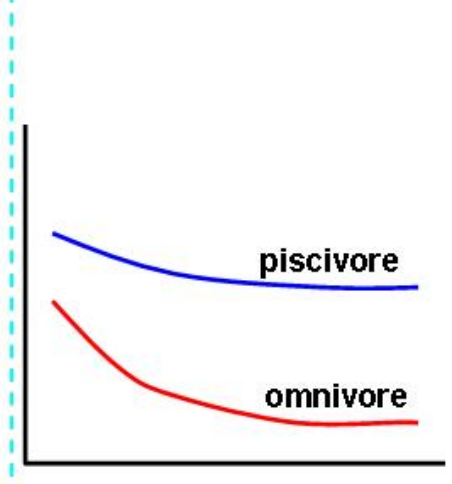

Fish concentration can be tracked through time in response to changes in flow, temperature, $\mathrm{Hg}$ input, etc.

Stella; M. Bevehimer

Fig. A.1.10. 2008. Mercury transport and accumulation model for East Fork Poplar Creek, using STELLA. Source: Mark Bevelhimer (ORNL), unpublished. Model used to evaluate changes in fish bioaccumulation with changes in temperature and flow through time. 


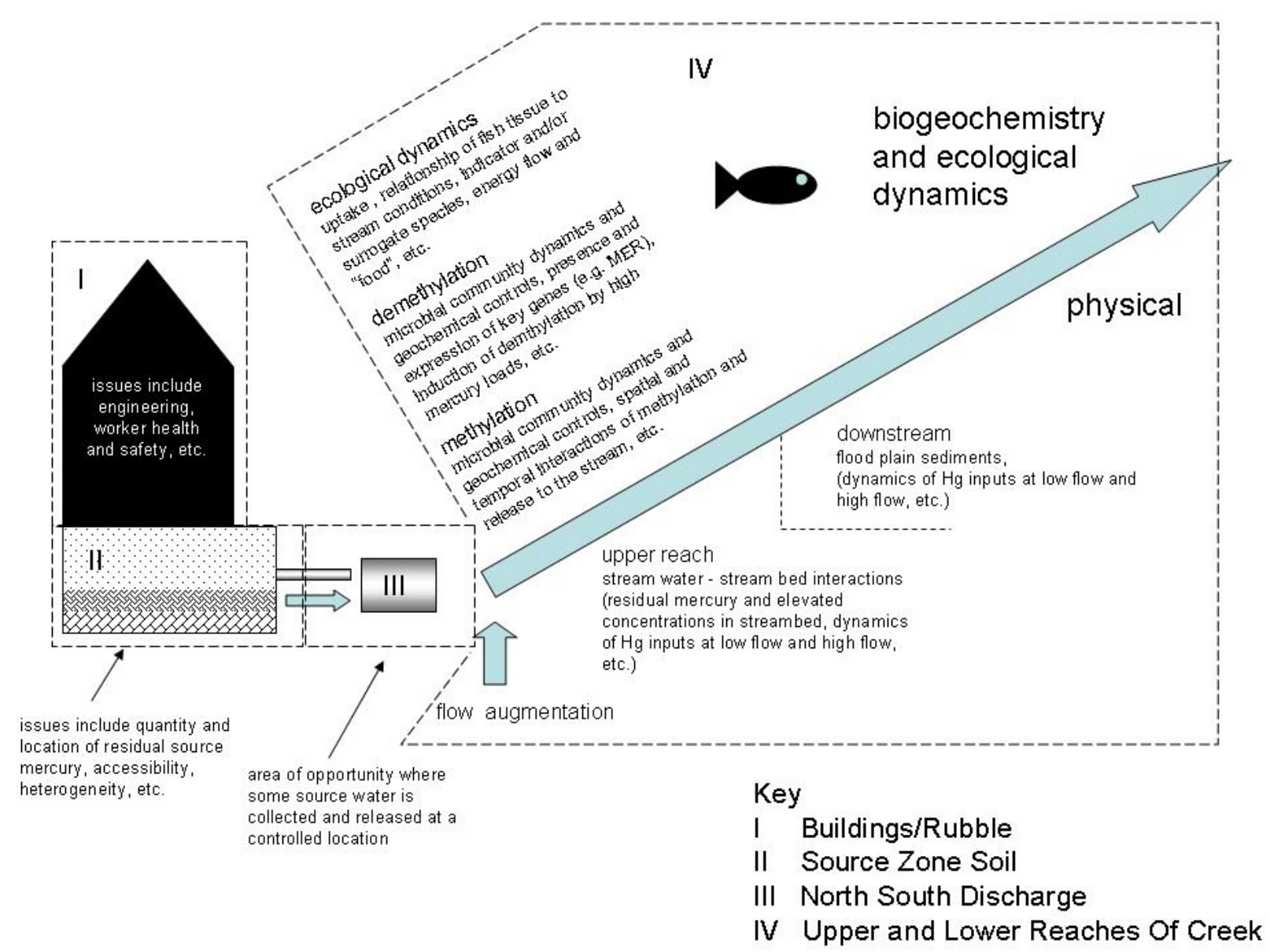

Fig. A.1.11. 2008. Conceptual model showing remediation issues in four domains: buildings and rubble, source zone soil, north/south discharge, and creek. Source: Looney et al. 2008. Used for EM-22 Technical Assistance Team meeting focused on East Fork Poplar Creek mercury issues. This depiction focused on processes within domain IV (upper and lower reaches of creek). 


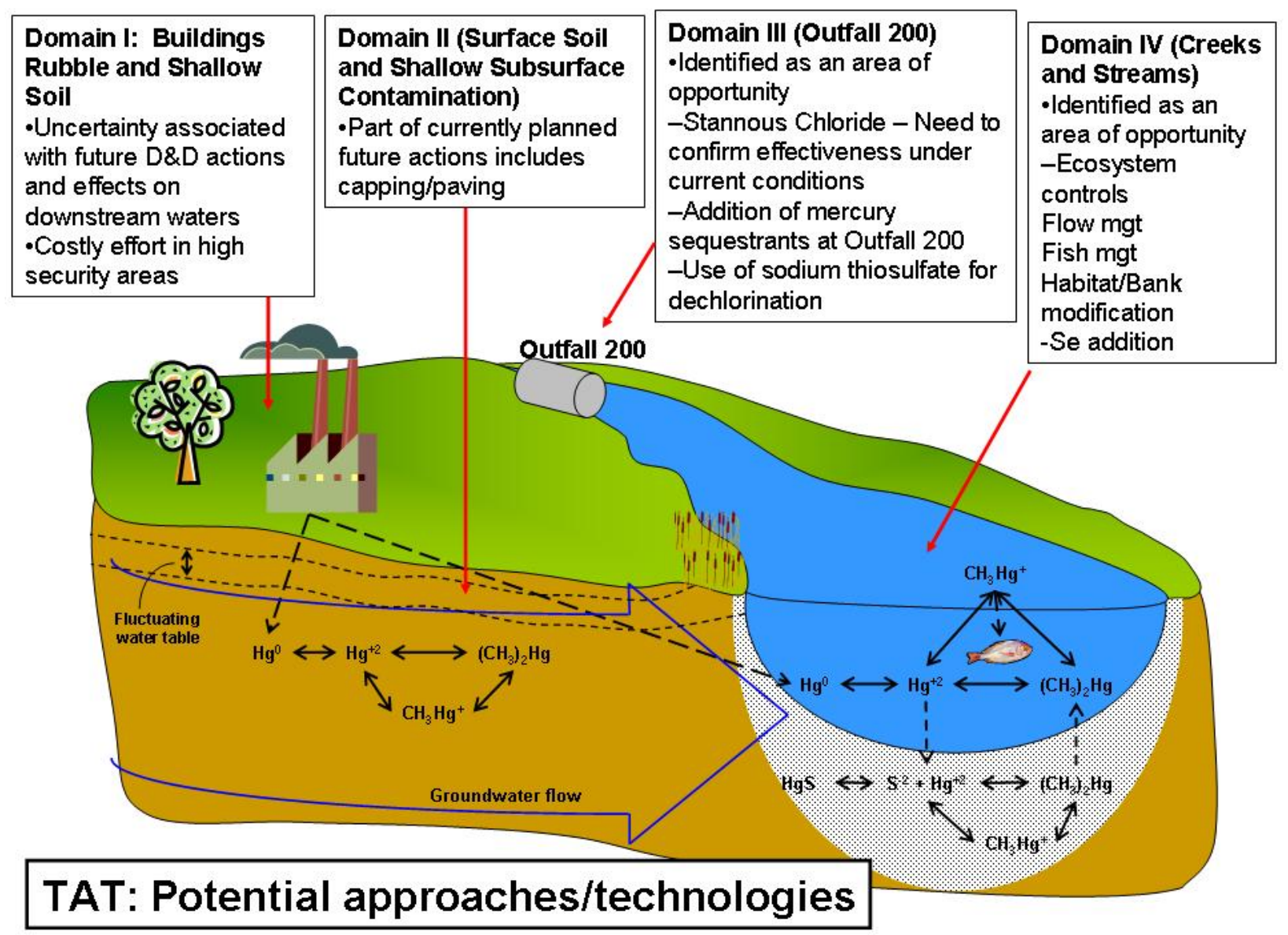

Figure A.1.12. 2008. Conceptual model showing remediation approaches or opportunities in four domains, with basic mercury chemistry interactions in subsurface, stream sediment and surface waters. TAT= Technical Assistance Team. Source: Looney et al. 2008. 


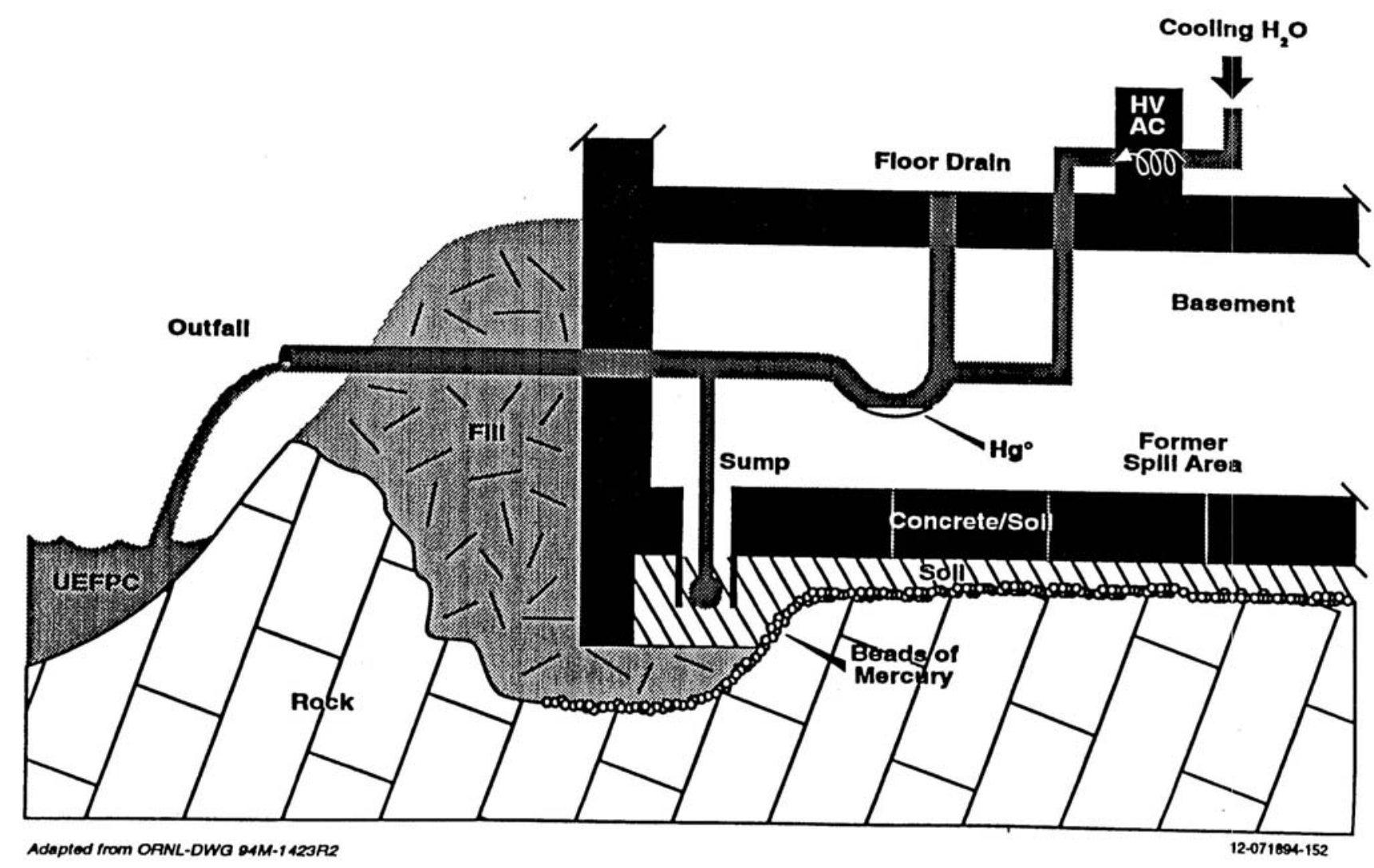

Fig. A.2.1. 1993. Foundation and equipment drains transport path to surface water. Source: Norris 1993. Model of building mercury interactions used as part of integrated strategy for mercury remediation on the Oak Ridge Reservation. 


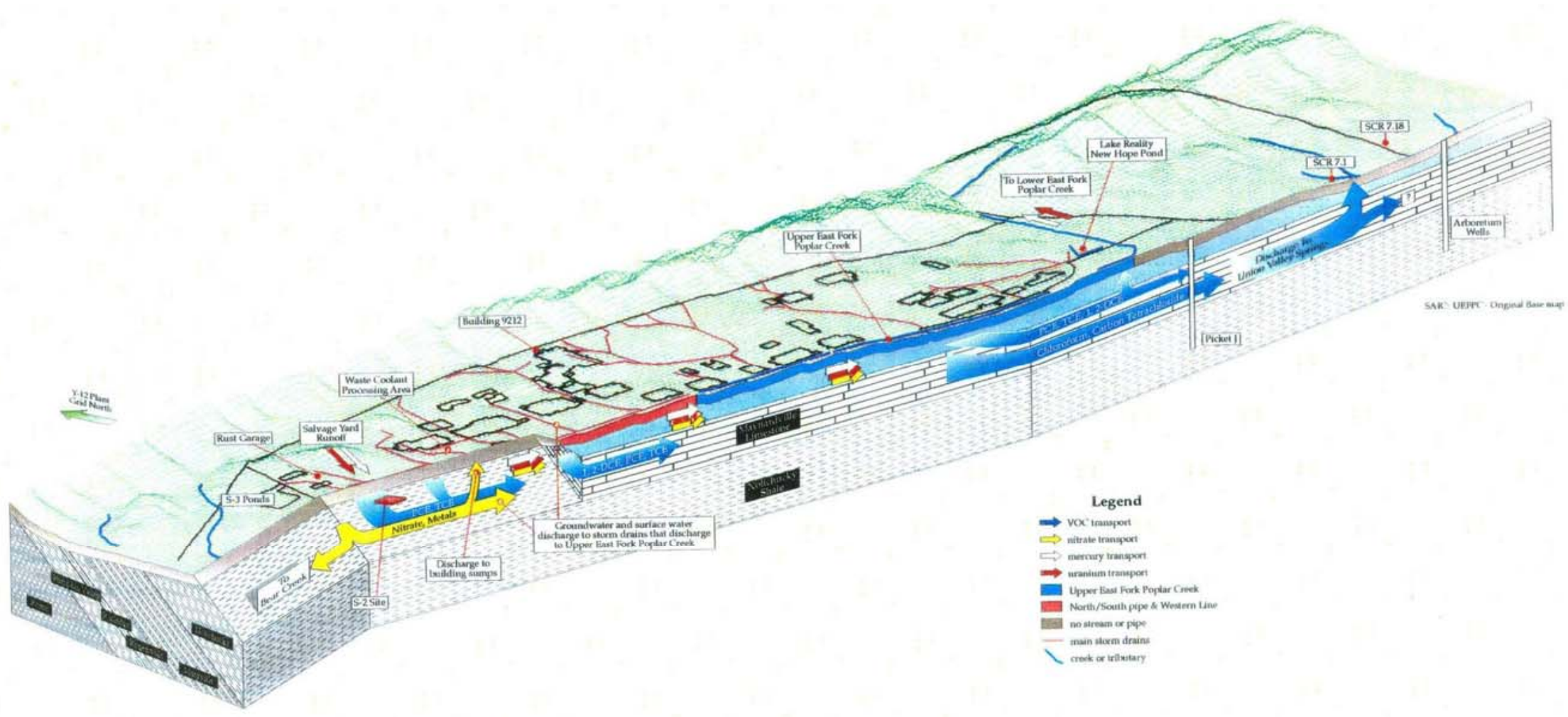

Fig. A.2.2. 1997. Conceptual site model for UEFPC. Source: DOE 1997. Conceptual models were generated for major watershed units as part of a strategy to integrate groundwater, surface water, and biota sampling. 


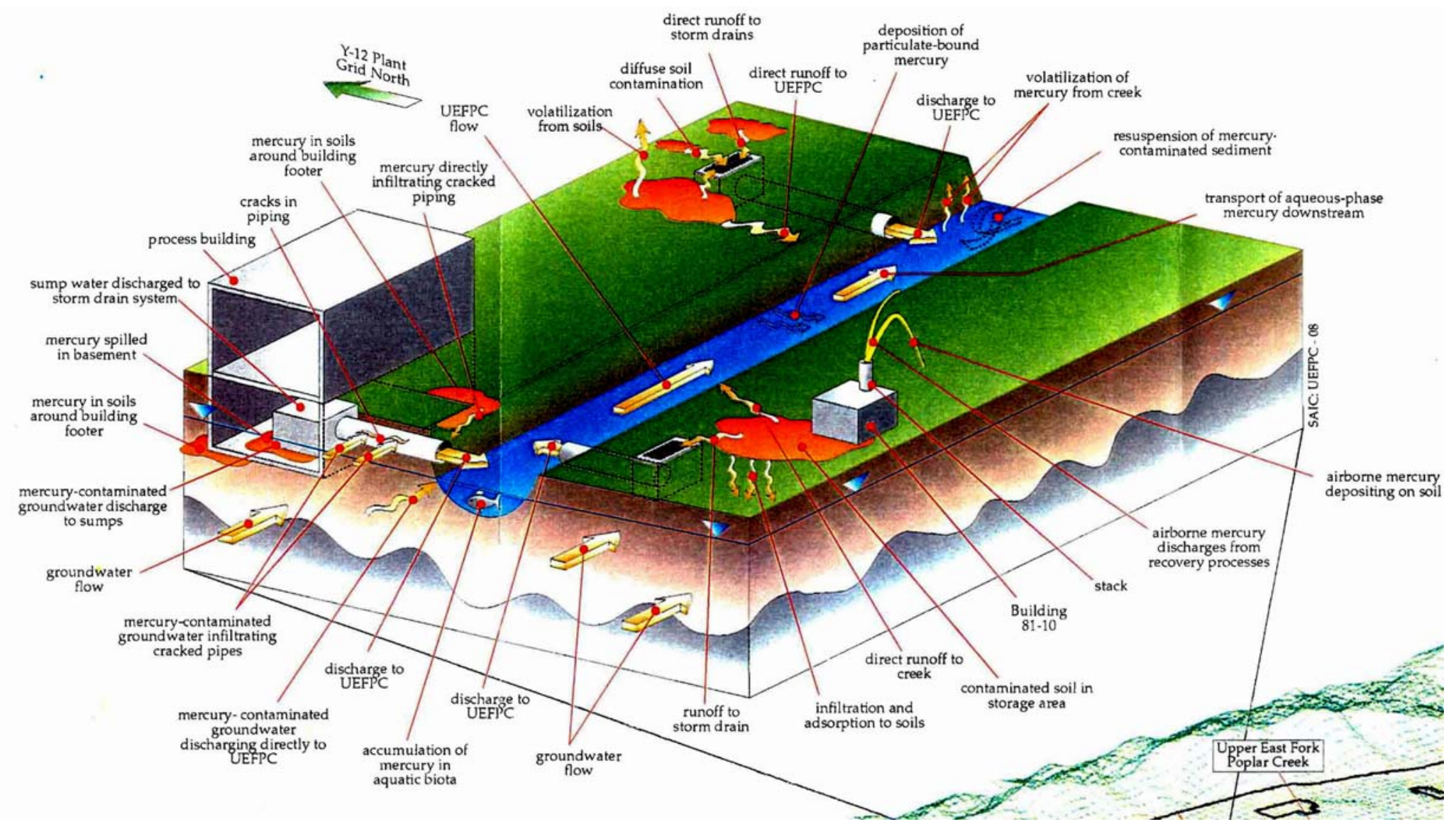

Fig. A.2.3. 1998. Conceptual model of mercury sources and major flow paths, Y-12 Complex. Source: DOE 1998. Model used as part of remedial investigation of the Upper East Fork Poplar Creek Characterization Area at the Oak Ridge Y-12 Plant. 


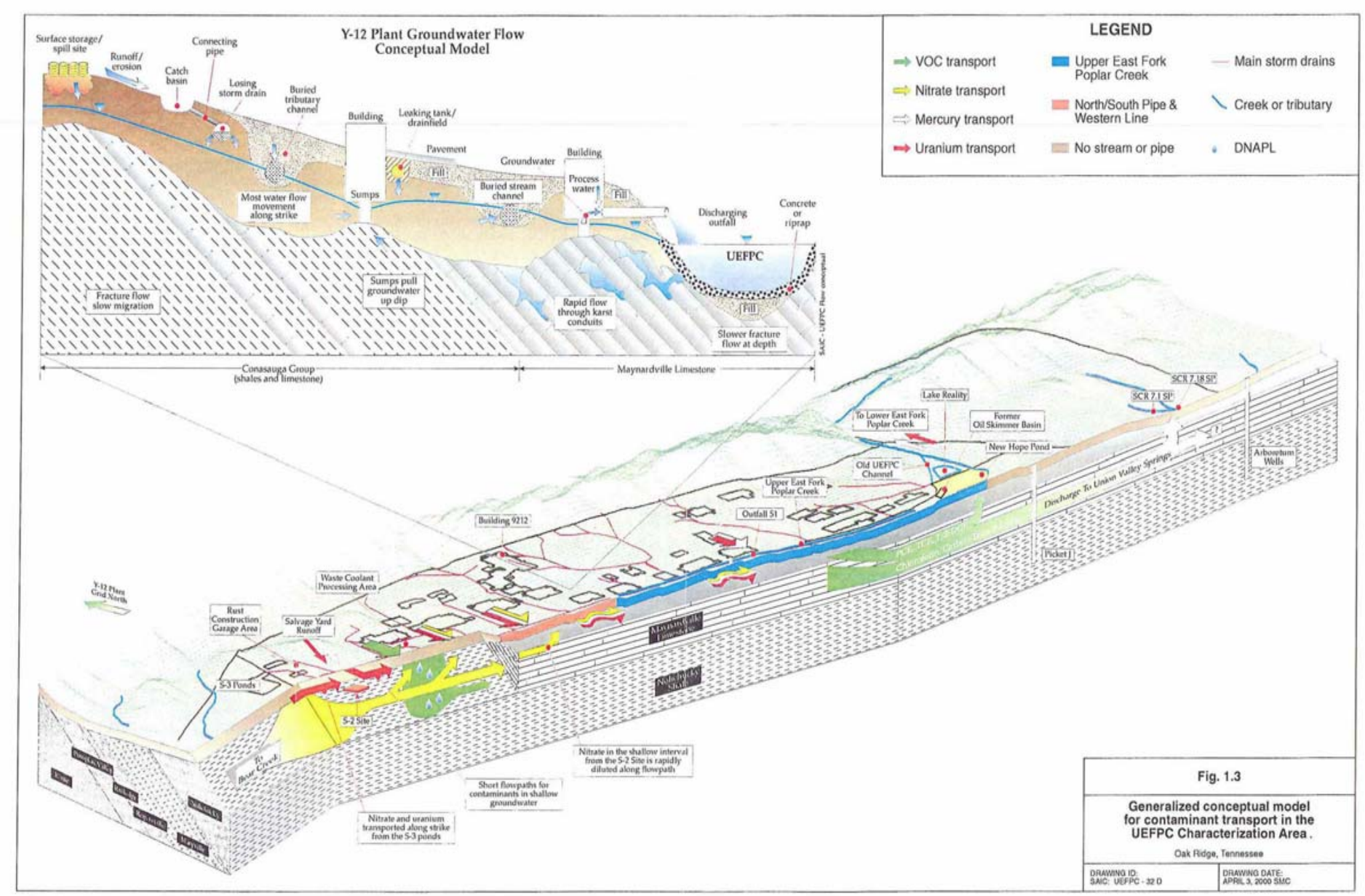

Fig. A.2.4. 2000. Generalized conceptual model for contaminant transport in the UEFPC Characterization Area. Source: DOE 2000. 


\section{A.3 SOURCES AND TRANSPORT PATHWAYS}

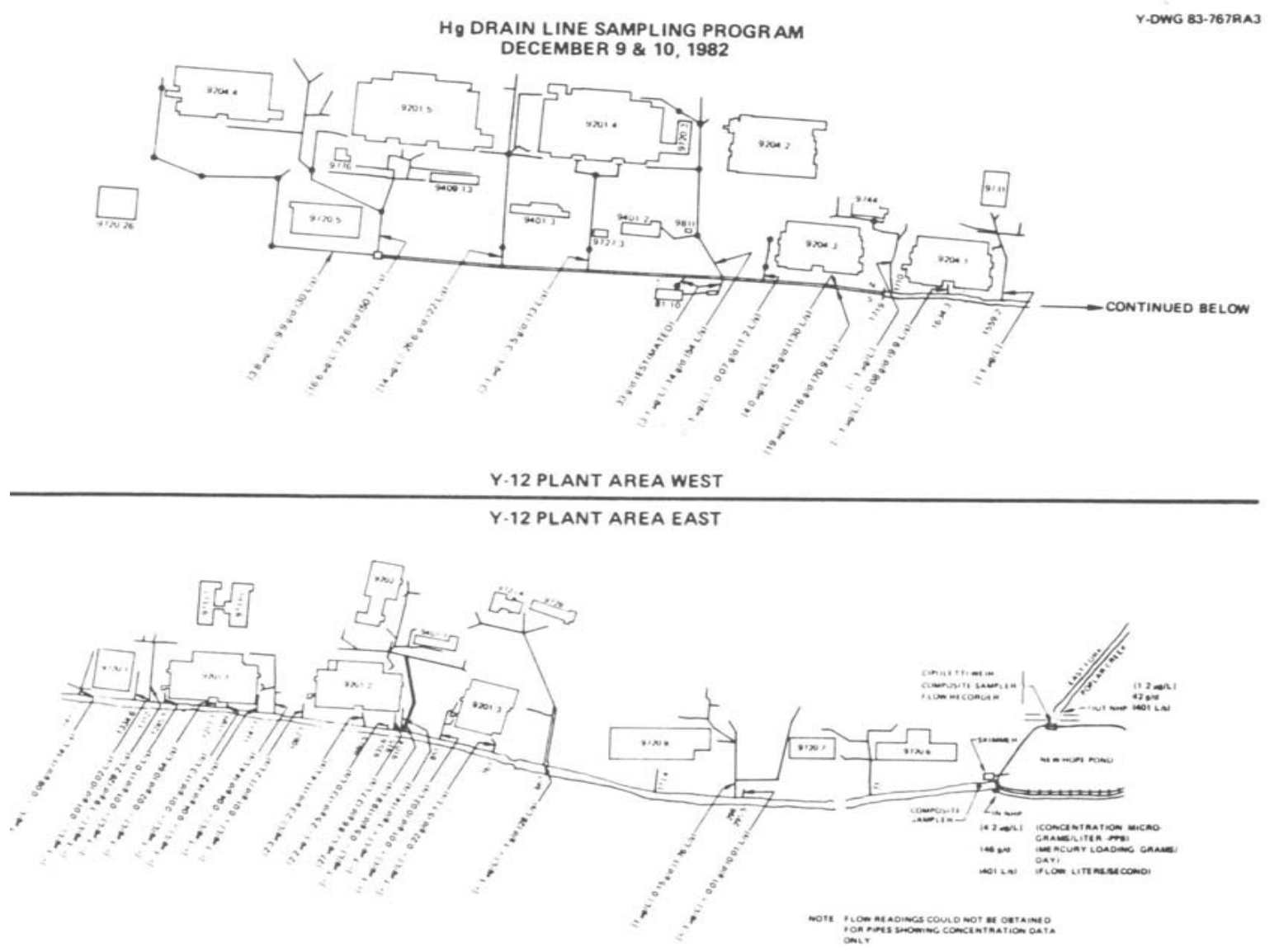

Fig. A.3.1. 1983. Sampling locations and results from the December 9-10, 1982, check of Y-12 Plant drain lines for mercury content. Source: UCC 1983b. Perhaps the first diagram to indicate mercury flow paths at the Y-12 Plant. 


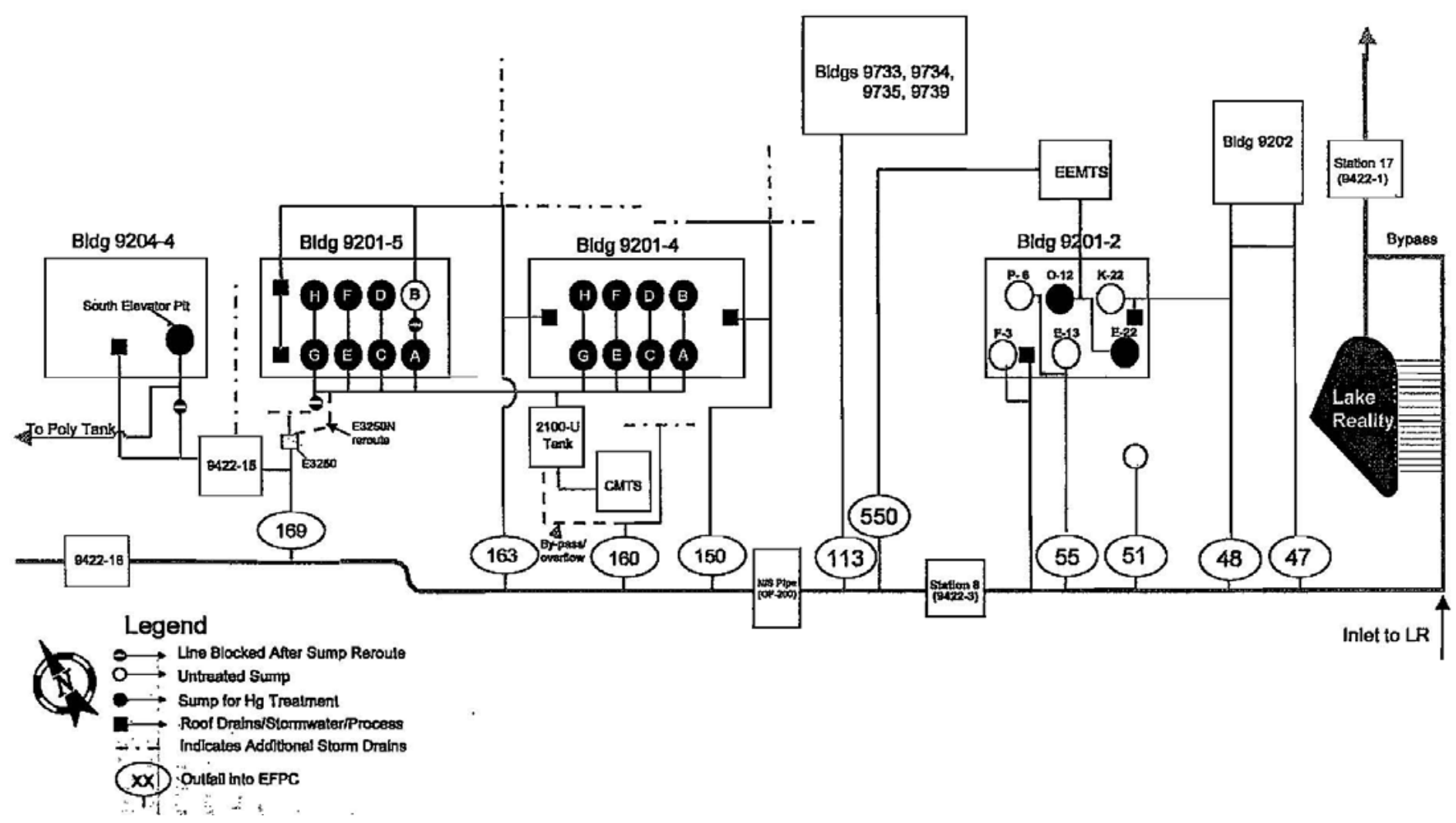

Fig. A.3.2. 1998. Schematic of buildings, sumps, storm drains, outfalls, mercury treatment systems, and surface water monitoring locations relevant to the Y-12 Plant's mercury abatement program. Source: BJC 1998. 


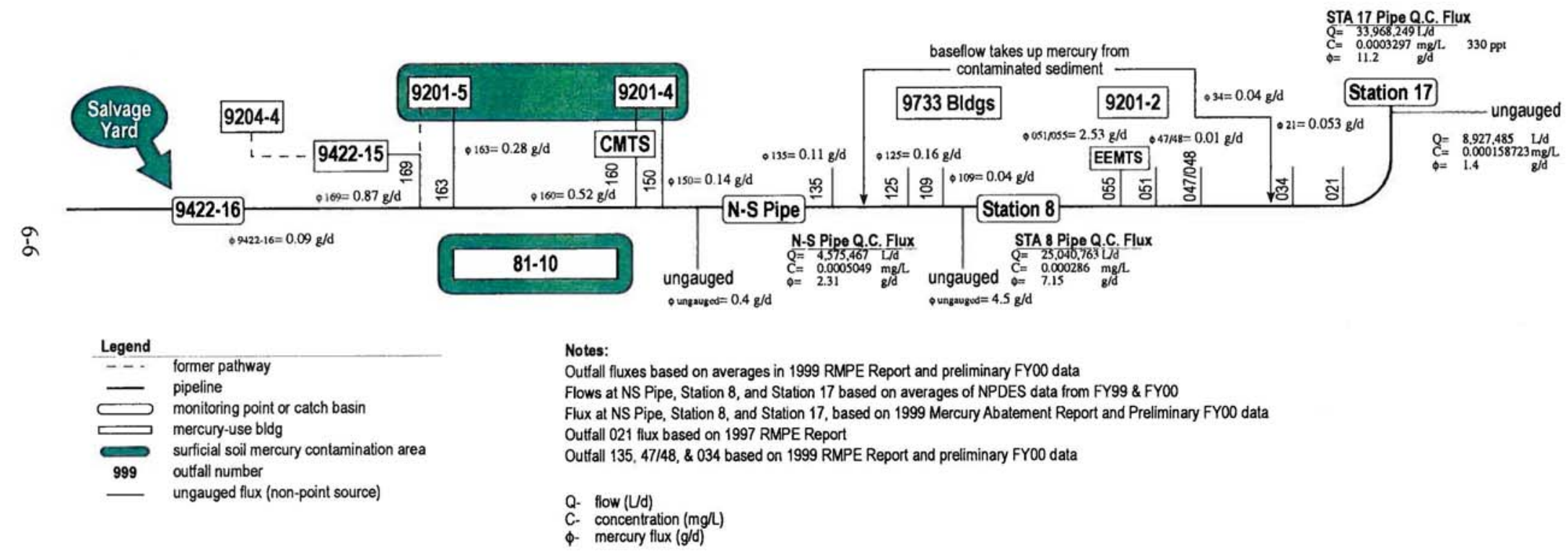

Fig. A.3.3. 2002. Mercury flux conceptual model: current conditions. Source: DOE 2000. Baseline flux used to assess potential mercury concentration and flux changes associated with various interim source control actions (as part of feasibility study). Includes concentration and flux numbers in the year 2000 after flow management and bank stabilization actions. Considered qualitative conceptual model. 


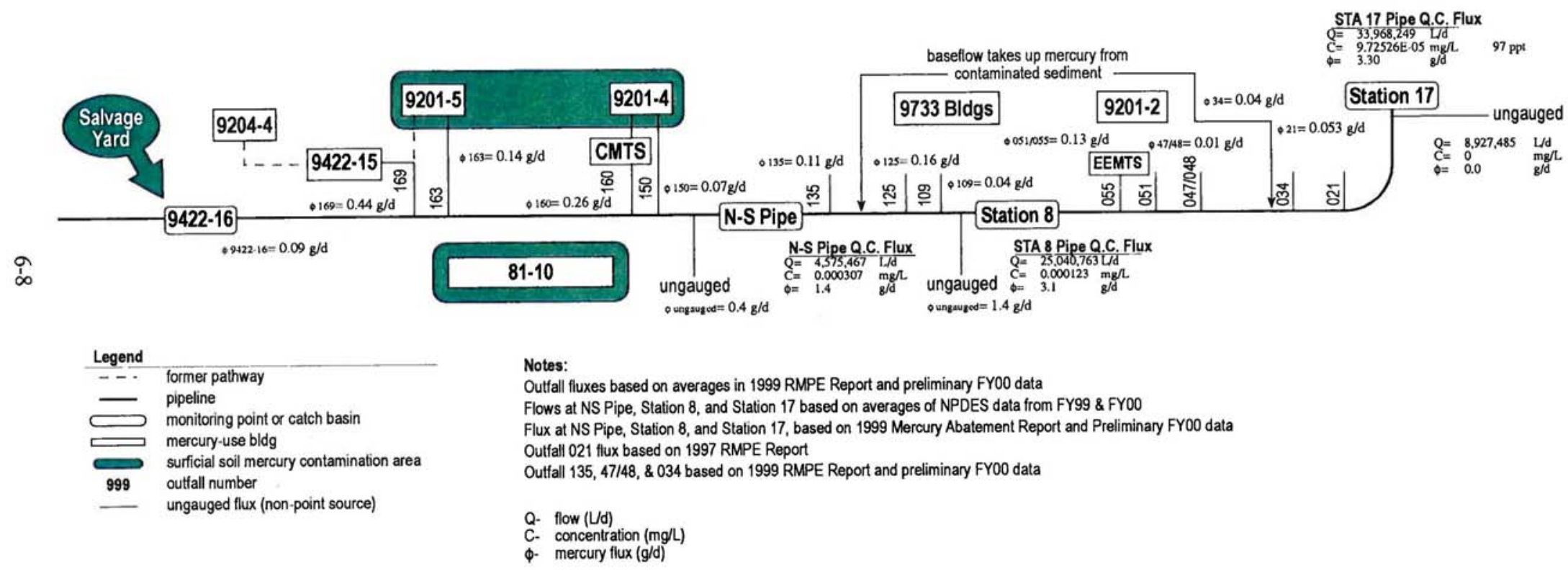

Fig. A.3.4. 2002. Mercury flux conceptual model: postremediation. Source: DOE 2000. Modeled reduction of flux if preferred alternative implemented. Model used for evaluating mercury concentration and flux changes associated with various interim source control actions (as part of feasibility study). Considered qualitative conceptual model. 


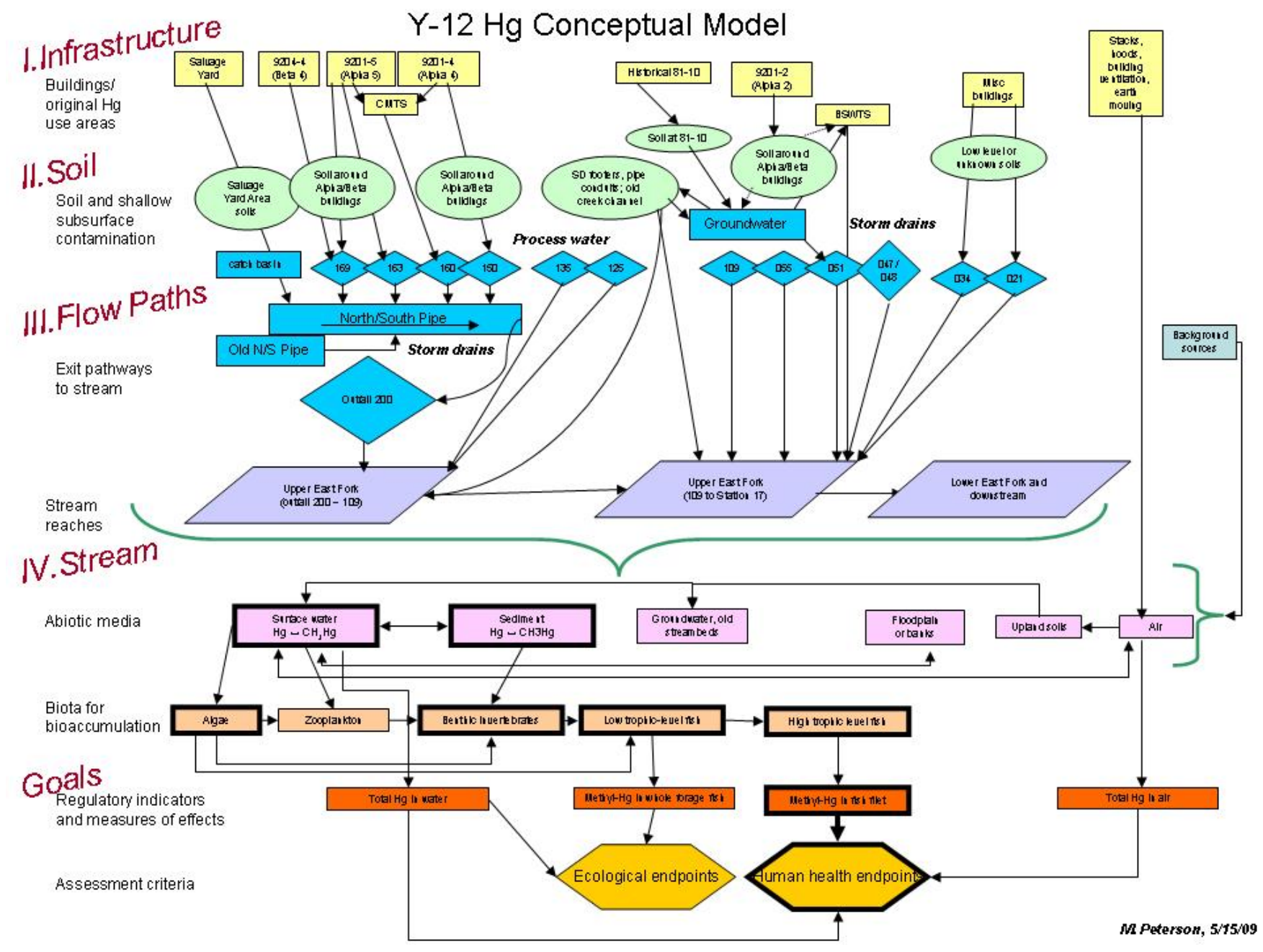

Fig. A.3.5. 2009. Conceptual model for mercury at the Y-12 Complex. Source: Peterson and Efroymson (ORNL), unpublished. Model composed to help address Clean Water Act compliance/National Pollutant Discharge Elimination System goals. 


Y-12 Complex and Upper East Fork Poplar Creek, Oak Ridge, Tennessee

\section{APPENDIX B. TECHNICAL TEAM BIOGRAPHIES}



Mark J. Peterson

Oak Ridge National Laboratory

Oak Ridge, TN 37831-6351

(865) 576-3461

petersonmj@ornl.gov

Mark Peterson is the leader of the Ecological Assessment Team in the Environmental Sciences Division at Oak Ridge National Laboratory (ORNL) and the program manager of the Biological Monitoring and Abatement Program—a long-term multidisciplinary monitoring program implemented primarily in Oak Ridge, Tennessee. As both a principal investigator and program manager, he has evaluated the aquatic environment near the Y-12 National Security Complex since 1988, including assessment of changes in mercury contamination in fish. He has more than 25 years of environmental assessment experience, with the last 20 years focused on the bioaccumulation of contaminants near Department of Energy (DOE) and Department of Defense sites. Related to mercury, he was a co-investigator for the Lower East Fork Poplar Creek Remedial Action Project and Reduction of Mercury in Plant Effluent (RMPE) Program (both in Oak Ridge); the Mercury Experiment to Assess Atmospheric Loading in Canada and the United States in Ontario, Canada; and the Barrow Arctic Mercury Study in Alaska.

\section{Brian B. Looney}

Savannah River National Laboratory

Building 773-42A, Aiken, SC 29808

(803) 7253692 or (803) 7252418

brian02.looney@srnl.doe.gov

Brian Looney is a fellow research engineer at the Savannah River National Laboratory. While in this position for the past 15 years, he has coordinated development and deployment of environmental characterization and cleanup technologies. Dr. Looney has successfully performed environmental projects on a wide range of topics. For example, he was the principal investigator responsible for the first largescale application of horizontal drilling to environmental remediation. Other successful research efforts have included soil-gas survey techniques for hazardous waste sites, barometric pumping for vadose-zone cleanup, gas-phase nutrient addition to stimulate bioremediation, and various topics associated with modeling and risk assessment. Dr. Looney currently holds five U.S. and one foreign patent for environmental technologies. Most of these are licensed to environmental engineering companies and in use throughout the United States. Dr. Looney, in collaboration with others, contributed to recent field studies at the Mayak Site (a former nuclear production facility) in Russia. Recently, he co-edited the book Vadose Zone Science and Technology Solutions. He also led the successful efforts to redefine the Subsurface Contaminants Focus Area technical program in terms of technical targets within which research and development programs could be developed.

\section{George R. Southworth}

Att: Teresa J. Mathews

Oak Ridge National Laboratory

Oak Ridge, TN 37831-6351

mathewstj@ornl.gov

George Southworth recently retired from ORNL after 35 years of research in the fields of environmental chemistry and toxicology. His research background is in the environmental transport and transformation of chemicals in surface waters and groundwater and studies of the toxicological and ecological effects of chemicals on aquatic organisms and communities. He worked in the Biological Monitoring and Abatement Program at ORNL beginning in 1985 as principal investigator and group leader, with primary emphasis on the bioaccumulation of mercury, polychlorinated biphenyls, and other metals and organic 
chemicals. In 1997 he became lead scientist in the RMPE Program at the Y-12 National Security Complex. In that role he participated in studies of new treatment technologies (chemical reduction/air stripping) and helped identify previously unrecognized sources of mercury contamination to East Fork Poplar Creek (metallic mercury in streambed sediments). In 1999 he began working on several Environmental Protection Agency and DOE-funded studies of mercury cycling between the atmosphere and aquatic and terrestrial systems in Alaska, Canada, Florida, and the upper Midwest. Most recently he was a key participant in DOE's research on the environmental behavior of mercury on the Oak Ridge Reservation.

\section{Carol Eddy-Dilek}

Savannah River National Laboratory

Building 773-42A, Aiken, SC 29808

(513) 5933969

carol.eddy-dilek@srnl.doe.gov

Carol Eddy-Dilek is an environmental scientist at the DOE Savannah River National Laboratory in Aiken, South Carolina. For the past 21 years, she has facilitated development of innovative approaches and tools for environmental characterization and remediation, particularly cone-penetrometer methods for solvent and dense, nonaqueous-phase liquid investigations. Her efforts resulted in the successful development or deployment of more than 50 innovative methods for subsurface access and characterization applied within the DOE complex. For 3 years she coordinated technical assistance activities for the DOE Ohio Closure Sites (Fernald, Ashtabula, and Mound), which provided technical experts to address challenging environmental issues encountered during the expedited closure process. She currently is the technical lead on a DOE Headquarters characterization program and the coordinator for the technical assistance program within the Center for Sustainable Groundwater and Soil Solutions at the Savannah River National Laboratory.

\section{David Watson}

Oak Ridge National Laboratory

Oak Ridge, TN 37831-6038

(865) 241-4749

watsondb@ornl.gov

Dave Watson is a hydrogeologist with diverse technical skills and more than 27 years experience managing surface water, groundwater, and vadose-zone investigations and remediation projects. He has managed large federal and state Superfund projects, and as manager of CH2M-Hill's Portland, Oregon, groundwater department, he was responsible for coordination and implementation of all hydrogeologyrelated projects completed in the office. Since 1993 he has been a hydrogeologist at ORNL, providing technical assistance and oversight to the Environmental Management and Groundwater Protection Programs. He was the technical lead for the Y-12 Bear Creek Valley and Upper East Fork Poplar Creek watershed remedial investigations, risk assessments, and feasibility studies and project manager on the Y12 permeable reactive barrier projects. Through this experience he has developed a detailed understanding of the fate and transport, assessment of risk, and remediation of contamination (especially mercury) in the environment at Y-12. He is currently the DOE Subsurface Biogeochemical Research Program Field Research Center (FRC) manager. The FRC is located on the west end of Y-12 and has a mission of conducting advanced scientific subsurface research, the results of which are being used to conduct contaminant characterization, fate and transport, and remediation activities at Y-12 and other DOE sites. 


\section{Richard Ketelle}

Bechtel Jacobs Company LLC

K-1225, East Tennessee Technology Park

Oak Ridge, TN 37849

(865) 574-5762

ketellerh@bechteljacobs.org

Richard Ketelle presently serves as the technical lead for the Bechtel Jacobs Company LLC Water Resources Restoration Program (WRRP). As technical lead for CERCLA activities at all three Oak Ridge facilities, he conducts a wide variety of groundwater and surface water monitoring and remediation activities. He is the primary author of groundwater sections of the annual Remediation Effectiveness Report in Oak Ridge, and contributes his expertise to CERCLA core team meetings at which the efficacy of various remedial action options is determined. Relative to mercury, he leads CERCLA studies of mercury flux in storm drains and creeks at Y-12 and ORNL.

\section{Mary Anna Bogle}

Oak Ridge National Laboratory

Oak Ridge, TN 37831-6038

(865) 5747824

boglma@ornl.gov

Mary Anna Bogle retired from ORNL after more than 30 years of applied environmental chemistry research, including decades of experience studying mercury processes at the Y-12 Complex. She was a scientist working for the RMPE Program at the Y-12 Complex in the 1990s and early 2000s. She has extensive experience evaluating the role of mercury from storm drain sources within the Y-12 Complex, especially within the West End Mercury Area. In addition to studies in Oak Ridge, she has worked on several EPA- and DOE-funded studies of mercury cycling between the atmosphere and aquatic and terrestrial systems. She is currently working as an ORNL subcontractor for the EM-32 program in Oak Ridge. 
